\title{
THE PAST, PRESENT, AND FUTURE OF TUNA AT LAKE MOĀWHITU: Drawing from the two knowledge baskets of Mātauranga Māori and Western Science
}

HE REO NO TE PUEHU - A VOICE FROM THE DUST

By

Russleigh Ika Parai

A thesis

Submitted to the Victoria University of Wellington in fulfilment of the requirements for the degree of Master of Science

Victoria University of Wellington

(2020) 


\section{ABSTRACT}

Knowledge generated through experience and understanding relies on the senses, one of which is listening. This thesis provides an opportunity to hear the diminishing voice of tuna utilizing paleolimnological techniques and our natural senses through traditional Indigenous methodologies in order to track the presence of tuna back in time.

This study provides historical environmental context of Lake Moāwhitu catchment (Rangitoto ki te Tonga) as a once significant mahinga kai site for manawhenua, Ngāti Koata. The strong connection to place is not lost on Ngāti Koata despite for many their geographic detachment to their turangawaewae. They hear the voice of tuna calling them back to sustain them as they have sustained Māori from the beginning of time. Now considered wāhi tapu due to significant degradation, Moāwhitu is currently undergoing remedial intervention by Ngāti Koata, DoC, Lakes380 and stakeholders to restore the mauri (life force) of the Lake and adjacent wetland ecosystem.

Drawing from two distinct knowledge streams of western science and mātauranga Māori, this study draws new (on-site) understandings about the anthropogenic impacts on tuna as well as their status and relationship as tuākana (older sibling) to Māori. Through this journey a 'te ao Māori' (Māori worldview) is explored, revealing a historically healthy and abundant tuna population and thriving tuākana-teina relationship up until recent decades. This information complements the environmental reconstruction derived from western science methods applied to a lake Moawhitu sediment core spanning the last 1000 years or so. Through a combination of palynology, hyperspectral scanning and bacterial environmental DNA metabarcoding, it is clear that lake water quality remained high despite various historical land cover and land use changes, until recent decades when deteriorating quality has accompanied a rise in cyanobacteria and toxic algal blooms. These changes appear to coincide with intensified pastoralism accompanying draining of the lake and fringing wetlands since the mid-twentieth century. How tuna have endured these recent human impacts and why their survival and sustainability is important to Aotearoa today is at the heart of this thesis which seeks to explore how two vastly different knowledge streams converge and navigate unchartered waters. The two knowledge baskets (with their respective world views) are held up for the reader to view and consider what an effective collaborative partnership looks like 
by recognising basic intrinsic values of respect, reciprocity and kindness. The challenge remains to draw out the very best of people (he tangata) as a way to bring about urgent regenerative solutions for our tuākana, tuna, and in turn humanity itself (Fig. 1).
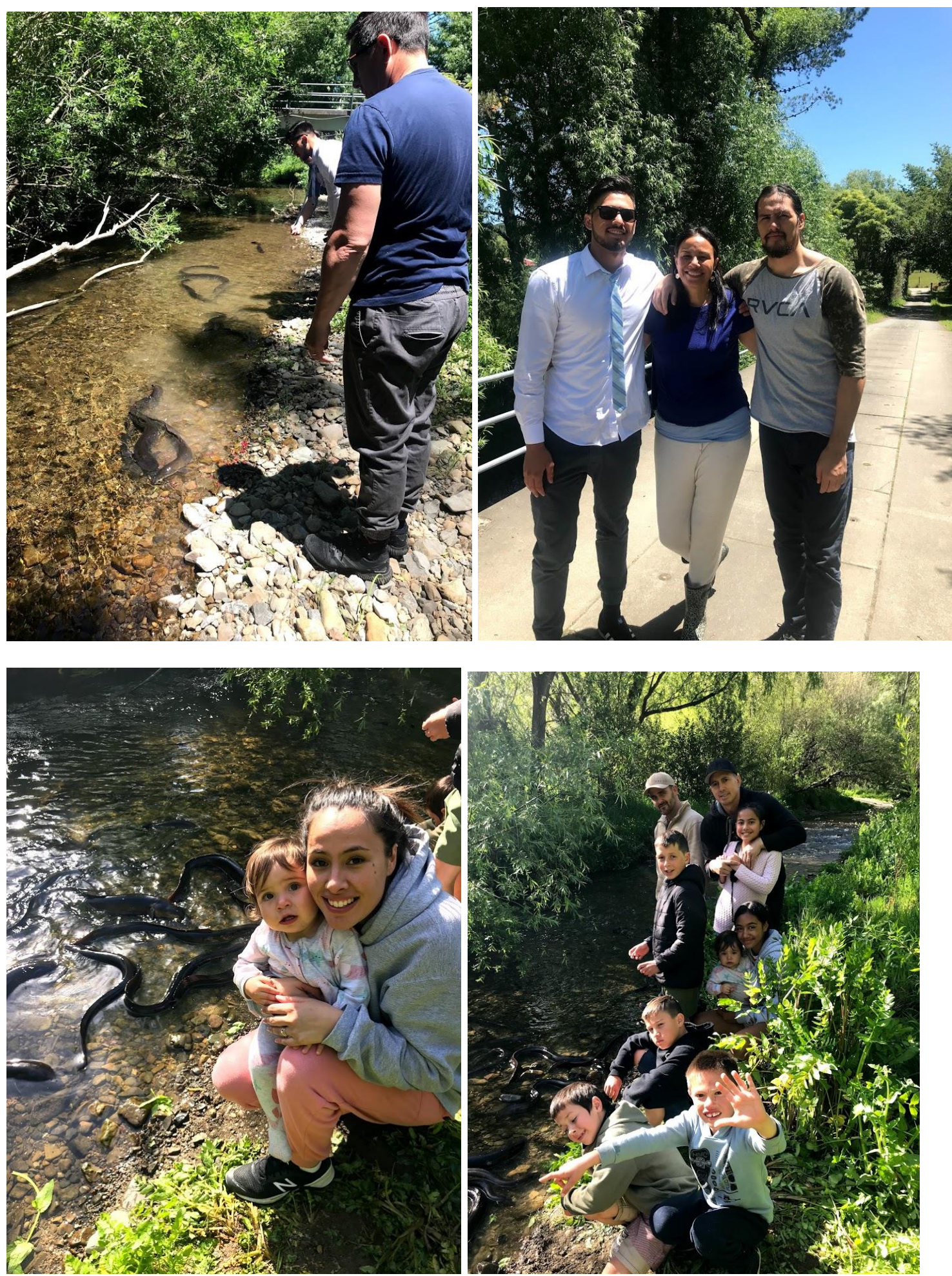

Figure 1 - (top left) Feeding the tuna with my sons - where their koro was taught hi-tuna by my koro. (Top right) My sons and their mum, Joanna, December 2018, Pauatahanui. (Bottom right) My mokos, son in law and niece. (Bottom left) My daughter and moko. Photos taken December 2019, Pauatahanui. 


\title{
PEPEHA
}

\author{
Ko Whitireia te Maunga \\ Ko Pari-rua te Awa \\ Ko Raukawakawa te Moana \\ Ko Takapūwāhia te Marae
}

Ko Ngāti Toarangatira rātou ko Ngāti Koata,

Ko Ngāti Raukawa, Ko Ngāti Tama, ko Ngai Tahu ngā Iwi.

Ko Tainui te Waka

Ko Waka Tiwai me Sonja tōku mātua

Ko Joanna tāku wahine

Tokorima ngā tamariki

E tekau āku mokopuna

\section{WHAKATAUKI}

(Te Tau Ihu)

KIA HIWA RA, KIA HIWA RA

MOE ARAARA KI TE MATAHI TUNA

MOE ARAARA KI TE MATAHI TAUA

KIA HIWA RA, KIA HIWA RA

Be prepared, be prepared

Sleep lightly, lest we miss the eel

Sleep lightly, lest we miss the war party

Be prepared, be prepared 


\section{ACKNOWLEDGEMENTS}

Na Pirikawau, ko Waka Tiwai, na Waka Tiwai, Ko tenei ahau..

Ko Waka Tiwai he ringa raupa, he kai kei ōna ringa, he tohunga hi-tuna,

Iti te kupu, nui te kōrero, nui te ngākau, nui te mahi

E Pa, hoki wairua mai, hoki wairua mai ra...

He mihi aroha ki a koutou, no reira tēnā koutou, tēnā koutou, tēnā anō tātou.

He mihi ki te Kaiarahi, he rangatira, my supervisor, Rewi Newnham for your unconditional support during this journey of enlightenment, discovery, triumph, failures, frustrations and great loss. Thank you for your understanding, foresight and compassion.

To the team that is Lakes380 (Susie, Marcus, Charlotte, Xavier, Georgia), and Te Wānanga o Wikitoria (Amanda Thomas and Rewi) I am very grateful for the opportunity, challenges and growth experienced during this haerenga. Your significant support, expertise and the ways you have engaged with manawhenua has been encouraging, respectful and inspiring. Thank you. To my good friend at DoC, Dan Moore who has guided the waka to Moāwhitu to ensure all parties are paddling, contributing and have a voice, ngā mihi nui e rangatira.

Me hoki whakamuri, kia haere whakamua

The lessons of our past will inform our future

To my whānau, my five tamariki, in-laws, out-laws, my ten mokopuna, my mum and loved ones I couldn't have accomplished the journey without being motivated by your very presence, your examples, your love, kindness, and commitment to your own journeys and kaupapa. Ka haere tonu whānau. 
To my wife, Joanna, I love you. I always have and I always will. You have encouraged me to keep going, to be an example to our kids, our mokopuna. Though you may not be at my side your wairua is ever present. You have and will continue to be a source of light, a beacon of hope in my life and the epitome of human kindness.

Moe mai ra tāku hoa wahine, moe mai ra wahine toa, he wahine ataahua, he wahine rangatira, moe mai ra ...til we meet again.

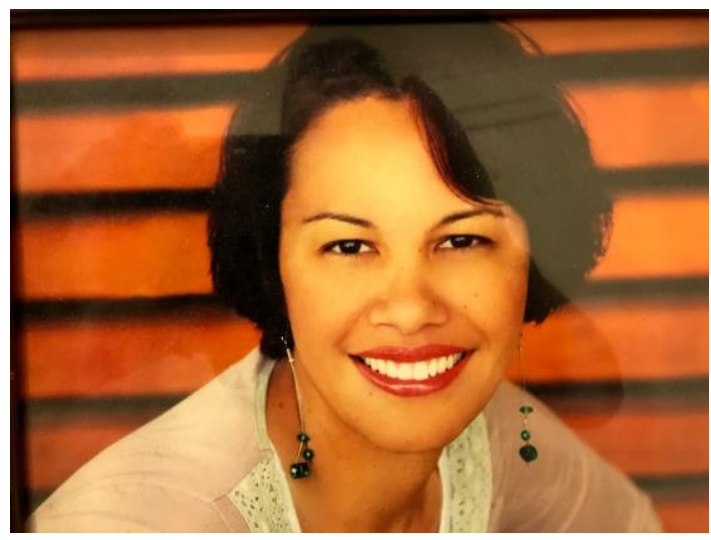

I runga i te kinokore, i te mātauranga, i te manawanui, i te ngākau ngawari, i te Wairua Tapu, i te aroha tinihangakore

2 Corinthians 6:6 


\section{CONTENTS}

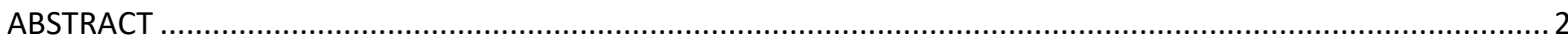

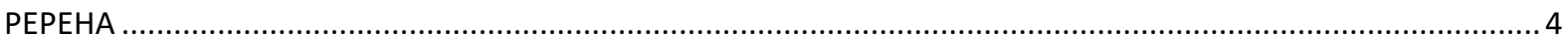

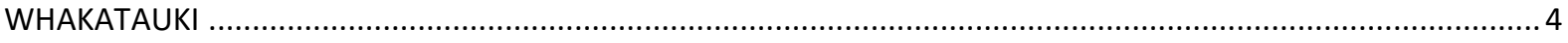

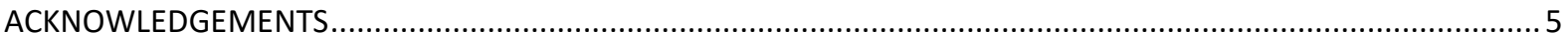

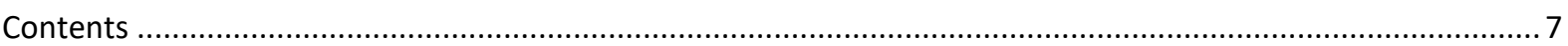

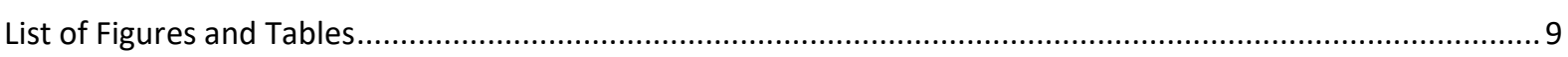

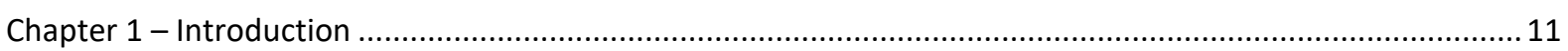

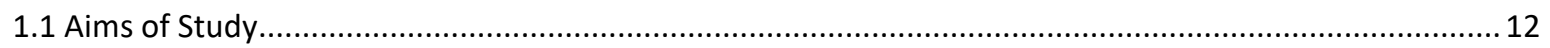

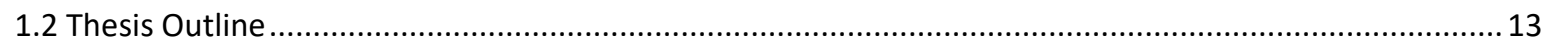

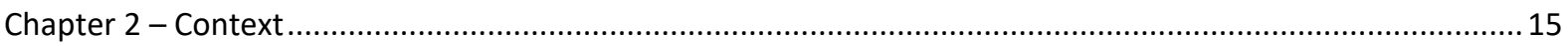

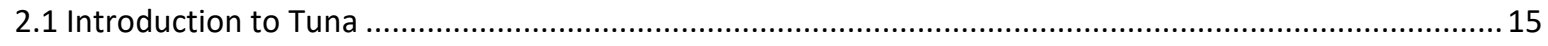

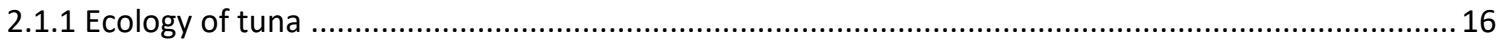

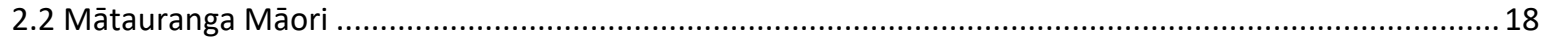

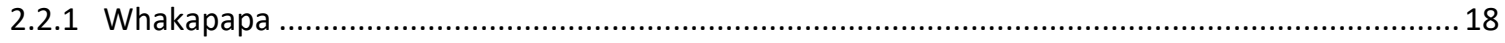

2.3 Lake Moāwhitu - Background and History ..................................................................................... 19

2.3.1 Ecological health of Moāwhitu: trends and issues ......................................................................... 20

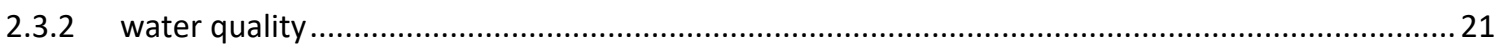

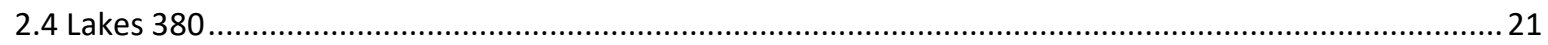

Chapter 3 - Biophysical data and Tuna eDNA ………….............................................................................. 23

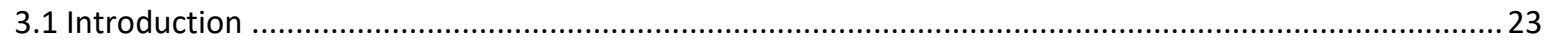

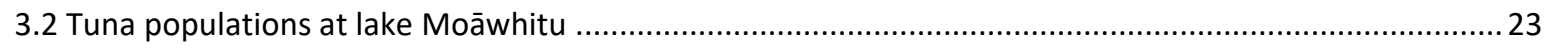

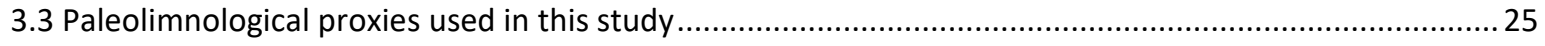

3.3.1 Pollen analysis for vegetation reconstruction and chronology .............................................. 25

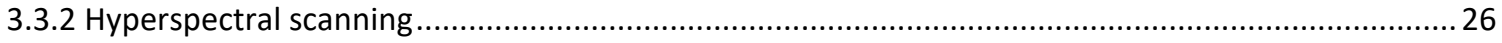

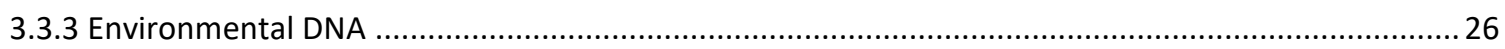

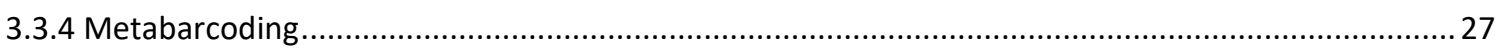

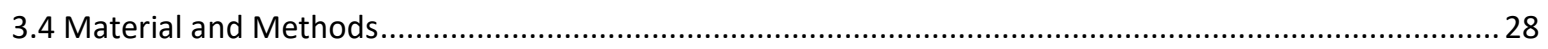

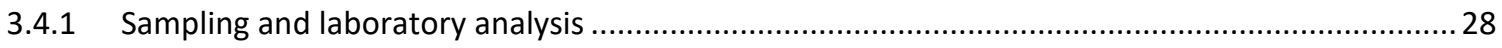

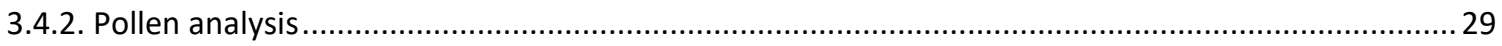

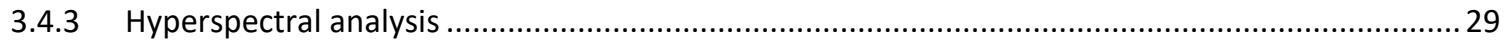

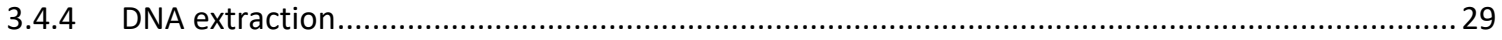

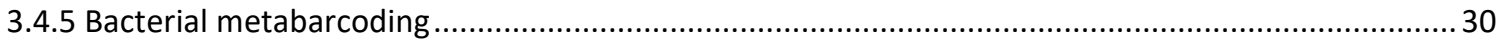

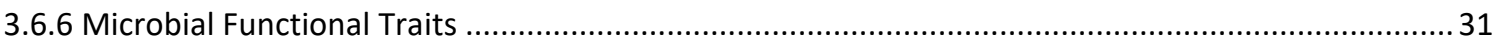

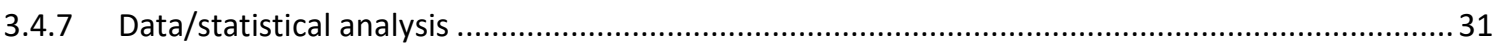




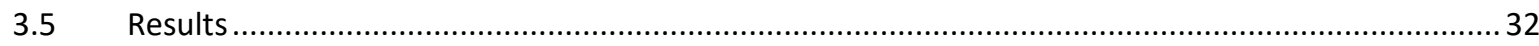

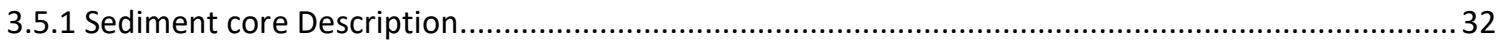

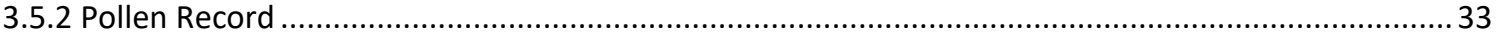

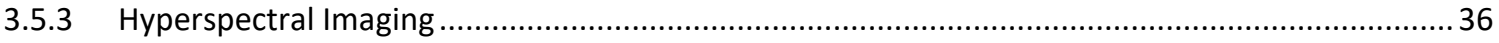

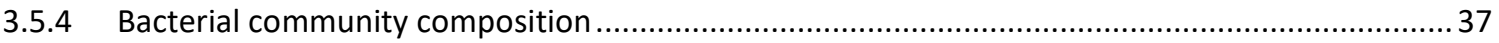

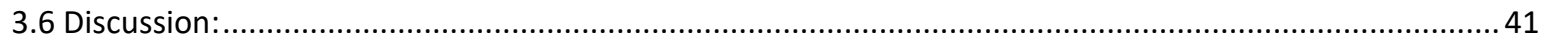

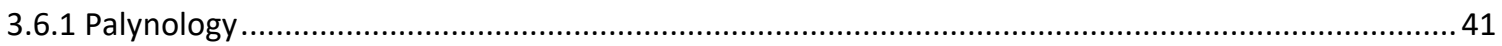

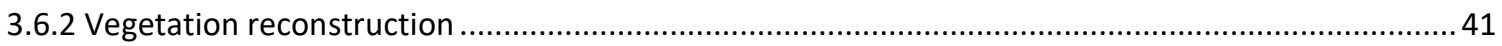

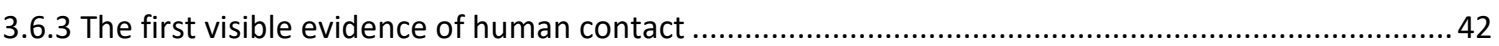

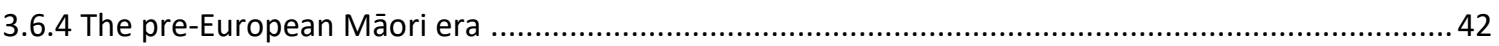

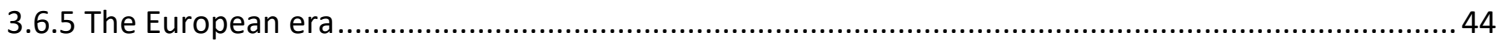

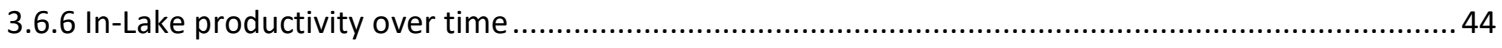

3.6.7 Bacterial community composition (Microbial) ..................................................................... 45

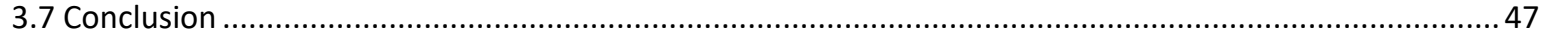

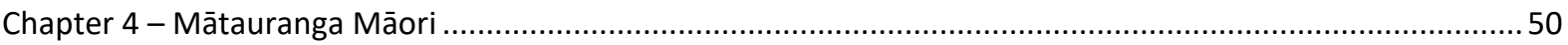

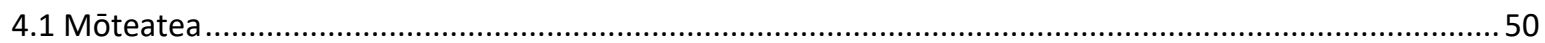

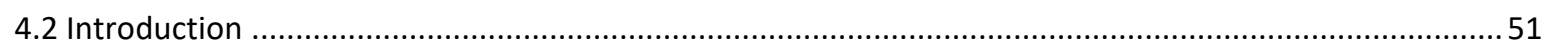

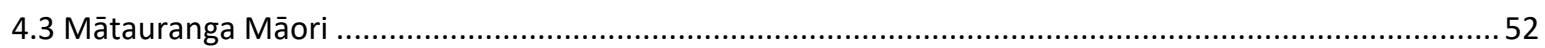

4.3.1 Mātauranga Māori and Western Science - The two 'knowledge baskets' ......................................55

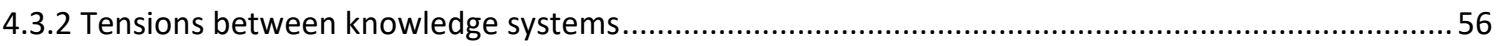

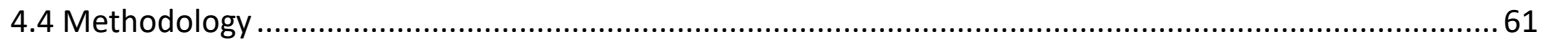

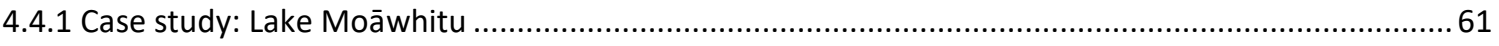

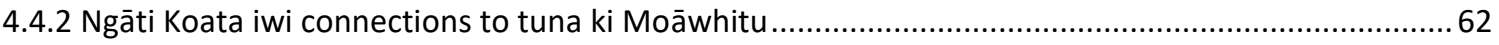

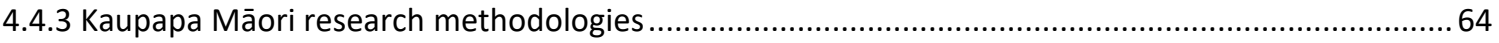

4.5 Findings: Cultural values and views expressed by Ngāti Koata members........................................... 71

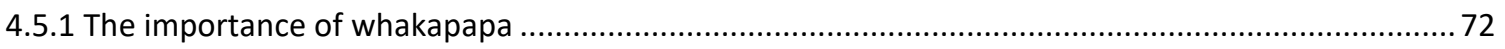

4.5.2 The importance of whanaungatanga and connections to place ..................................................... 76

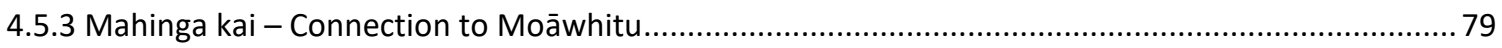

4.5.4 Kaitiakitanga and Te ao hurihuri: the changes to Lake Moāwhitu and the tuna population ..............83

4.5.5 Mauri and Wairua - Aspirations for restoration (Te Moemoeā) .................................................94

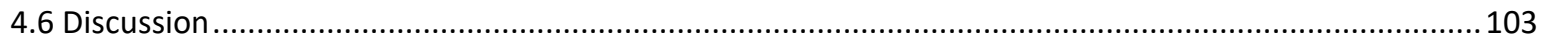

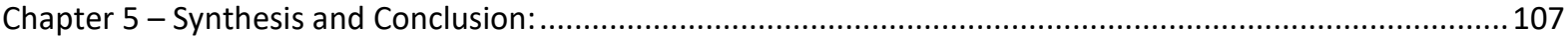

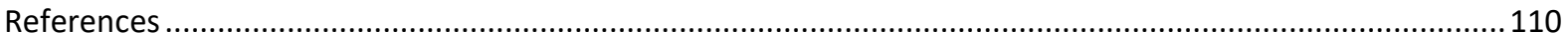

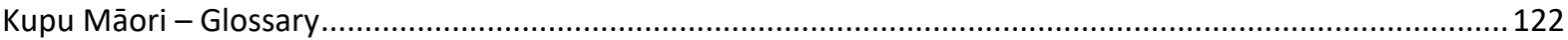

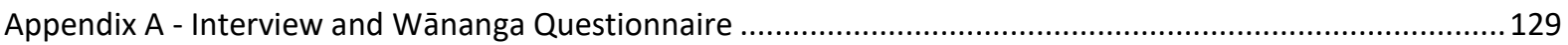

Appendix B - A guide for what a cultural indicator form could look like for Moāwhitu .................................. 131

Appendix C - Department of Conservation: Observations and Findings .............................................. 134 


\section{LIST OF FIGURES AND TABLES}

Figure 1 - Feeding tuna with my sons, 2017, Pauatahanui - where their koro was taught hituna by my koro..... 3

Figure 2 Image comparing characteristics of short-fin and long-fin tuna https://www.sciencelearn.org.nz/images/45-LF and SF eel 16

Figure $3 \mathrm{~A}$ schematic diagram of the life cycle of tuna and the possible threats associated with each stage (Jacoby et al, 2015).

Fig 4: Left: Lake Moāwhitu showing extent of lagoon prior to draining from 1948 and the easement used as access passage by Ngati Koata. Right: Location of Moāwhitu on Rangitoto ki te Tonga (bottom) in the northern-most Marlbrough Sounds (top) (Pätete, 1997).

Figure.5: More longfins are observed where bridges provide cover in the drains (photo taken in 2018)

Figure 6. Rush cover around fringe edges in Lake Moāwhitu, December 2018. .24

Figure 7 Photograph of Lake Moāwhitu sediment core split in half lengthways. Depth scale is in $\mathrm{mm}$. Note that the top of the core is shown as $11-12 \mathrm{~cm}$ due to the insertion of a core plug in the field. 32

Figure 8 Lake Moāwhitu percentage pollen diagram. Pollen and fern spore curves are percentages of the total pollen sum. Charcoal curves are number of charcoal shards observed per sample.

Figure 9. Hyperspectral ratio of the $660 / 670 \mathrm{~nm}$ band (green) in Lake Moāwhitu with mean value of 1.068 shown (red). Vertical lines signal the start/end of the time periods..36 Figure 10. Left panel: number of amplicon sequence variants (i.e. richness); Right panel (including key): Percent sequence abundance at the Class level.

Figure 11. Non-metric multidimensional scaling (NMDS) plot based on Bray Curtis distance matrices for Lake Moāwhitu bacterial eDNA samples grouped by the three historical phases. Depth $(\mathrm{cm})$ of each sample is given next to each point. 38

Figure 12. Time-series plots of three enzyme relative abundances (log-transformed) involved in key metabolic pathways - determined using the metabolic inference pipeline 
PAPRICA, then compared to the MetaCyc database to match sequences to a closest consensus genome and assign enzyme codes (EC numbers, https://www.brendaenzymes.org/index.php).

Figure 13. Hyperspectral plot (left), same data as for Fig.9), and the Cyanobacteria sequences extracted from the 16S rRNA metabarcoding data (right). Bloom forming cyanobacteria selected were Microcystis, Aphanizomenon and unclassified Nostocales. ...40 Figure 14 Whakapapa of tuna (Te Tau Ihu Mahi Tuna: Eel Management Plan, 2000) .........53 Figure 15: Generation of Māori knowledge. Modified from Graham (2009) .......................54 Table 1. Some differences between Mātauranga Māori and science (Hikuroa, 2017) ........57 Figure 16. Left: A 1923 mapsof Lake Moawhitu and adjacent wetlands [Reference source] -

Right: Lake Moawhitu today, showing the drained lake and wetlands (Drinan, 2018) .......86

Figure 17: Lake Moāwhitu evidence of algal blooms in summer for both 2018 and 2019..87

Table 2: Selective pollen taxa translated from Latin to Te reo Māori .89

Figure 18: Palynology findings at Lake Moāwhitu, vegetative names converted from Latin to te reo Māori 92

Figure 19: Fungal infection and parasite (circle) on a shortfin tuna caught in 2013 survey, links health of tuna to poor water quality .96 Figure 20: Koata and Doc collaborate Wetlands restorative strategies (left) which included dam constuction on the main outlet channel (2018). .96

Figure 21 1: Lake Moawhitu wetlands complex 97

Figure 22: Lake Moāwhitu wetlands inlet, where several glass eels were caught, assessed and released. .98

Figure 23. Wetekia Ruruka Elkington - Māreikura, Ngāti Koata .109 


\section{CHAPTER 1 - INTRODUCTION}

Tuna, a long-term indicator of ecological and cultural health, have undergone decline in numbers in recent decades, most likely due to a deterioration in water quality across Aotearoa. There is a need to set this recent decline in a longer-term context of natural variability and human activity in order to better understand why tuna and water quality decline are occurring. In this context, the focus of this thesis is Lake Moāwhitu (northwestern South Island), an important site for tuna harvesting by manawhenua Ngāti Koata. Lake Moāwhitu appears to be broadly representative of the wider issue of tuna and water quality decline across Aotearoa in relation to pastoral land use and commercial eeling in the past several decades. It is also the focus of recent collaborative efforts by Ngati Koata and Department of Conservation aimed at restoring the mauri (life force) of the lake.

The thesis develops a holistic approach to support these efforts by drawing on the two knowledge baskets of modern (western) science and traditional Māori knowledge (mātauranga). By interweaving both knowledge systems, perspectives, and findings the overall goal of this study is to develop historical knowledge on tuna in relation to land use and water quality at Lake Moāwhitu in order to better understand present conditions and inform future solutions. A key motivation of this thesis is to provide information that will help to develop solutions for restoration and future sustainability of tuna populations in the face of increasing anthropogenic pressures.

To serve this overall goal, the thesis explores the two knowledge baskets through the following aims. 


\subsection{AIMS OF STUDY}

(1) To investigate the environmental history of Lake Moāwhitu and its catchment over the past 1000 years, in order to gain a better understanding of why tuna populations have recently declined.

This aim is addressed through the application of a range of biophysical proxies applied to a sediment core from Lake Moāwhitu, in particular palynology to provide information on vegetation in and near the lake and its wetland margins, chlorophyll-a as a measure of lake productivity and environmental DNA analyses of in-lake bacterial communities.

In previous work for summer internships at Cawthron Institute, I was involved in the development of a molecular assay that specifically detects tuna in environmental samples (Thomson-Laing et al, 2020). It was initially planned for this thesis project to apply this assay to the Lake Moāwhitu core samples to characterize historic tuna population in the lake. However, logistical barriers arising from the COVI-19 pandemic and methodological challenges associated with extracting sufficient DNA from the core samples meant this was not possible during the time frame of my Master's degree.

(2) To listen, observe and connect with traditional Indigenous knowledge to better understand the historic and intrinsic value of tuna and the practice of mahinga kai for Ngāti Koata kaitiaki in the context of aspirations for lake restoration.

This aim is to recreate through wānanga, kanohi ki te kanohi, and historic accounts, a time and place where the whakapapa and connection to tuna has been well established and documented through Indigenous methodologies to support and/or weave key strands of information that may inform on the historic health and abundance of tuna at Lake Moāwhitu, and which may otherwise remain unknown. 


\subsection{THESIS OUTLINE}

This thesis is built around the above aims with separate chapters devoted to each aim and to the over-arching goal to interweave these knowledge streams.

Prior to these results chapters, chapter two provides background information about the important common elements of this thesis that apply to both knowledge baskets: the lifecycle and history of tuna, a brief introduction to mātauranga Māori, whakapapa including tuna's relationship to Māori, followed by an introduction to the study site. This thesis is a contribution to a wider five-year nationwide research programme, 'Our lakes' health: past, present and future' (or Lakes380) and has benefitted substantially from resources, expertise and information from that programme. Accordingly, this background chapter concludes with a brief overview of the Lakes380 programme and gives details of the inputs that this thesis has obtained from it.

Drawing on an expanding range of traditional and novel paleolimnological methods, the focus of chapter three is a study of sediment cores extracted from Lake Moāwhitu. Utilizing physical, chemical and biological information preserved in sediment profiles the objective is to reconstruct successional shifts in biological communities (Smol, 2017). The environmental reconstructions developed from the sediment cores are likely to capture about $\sim 1,000$ years of Lake Moāwhitu history. By identifying specific reference states (pre-human, evidence of Māori arrival, and post European arrival), an environmental history of the anthropogenic impacts on water quality and tuna populations is documented.

The environmental history of lake Moāwhitu is explored using data obtained from hyperspectral scanning to track changes in lake productivity, palynology to explore how vegetation in the catchment and lake margins has changed, particularly due to land use activities, and environmental DNA (eDNA) of microbial communities to provide insights into how in-lake communities and specific nuisance taxa like bloom forming cyanobacteria have changed in abundance. Although the chapter does not provide direct information on tuna history (as explained in 1.1), this holistic environmental reconstruction together with insights into tuna whakapapa presented in Chapter 4 enable some conclusions to be drawn about the nature and causes of tuna decline at Moāwhitu. 
Mātauranga Māori is an expanding body of Indigenous knowledge specific to Māori in Aotearoa, grounded in tikanga (values and practices), and linked to whakapapa (genealogical links to human and non-human) (Harmsworth \& Awatere, 2013). Chapter four provides a unique perspective compared to western science primarily based on "meaning" that is drawn from and connected to tūpuna (ancestors, of both Ngāti Koata and tuna), through the transmission of intergenerational knowledge. Drawing from wānanga and kānohi ki te kānohi (face to face), I seek to explore why Lake Moāwhitu has shifted from a mahinga kai site to wāhi tapu, and through the lens of mana whenua, why this significant site must be restored to its former status as mahinga kai. Both the epistemology and methodologies of mātauranga Māori are discussed and applied to explore how and why this independent repository of knowledge connects or weaves into western science to provide effective and meaningful remedial strategies to enhance tuna populations at Lake Moāwhitu.

From the study of Lake Moāwhitu, where tuna and Ngāti Koata connect, the final chapter highlights what this all means whilst identifying how two distinct worldviews with their respective kete of knowledge come together and make it work.

The final chapter presents a brief synthesis of the key findings drawn from the two knowledge baskets then concludes with some final words, as appropriate drawn from mana whenua concerning their approaches to lake restoration.

Finally, the fact that the biophysical chapter comes before the mātauranga chapter is not indicative of their relative importance in this thesis, quite the opposite in fact. One of the reasons why the biophysical chapter appears first is that it reveals a significant gap in the sense that we were unable to detect historical tuna presence at Lake Moāwhitu. The eDNA methodological study used to uncover the historical biodiversity at site was unable to give an indication of historical tuna populations at the time, as was originally hoped. This in turn helped to emphasise the importance of that question in the mātauranga research. 


\section{CHAPTER 2 - CONTEXT}

Drawing on common elements from the two distinct knowledge streams, background information relevant to this thesis is presented. This chapter includes an introduction to tuna health and population and considers the relationship between tuna and Māori through whakapapa within the body of mātauranga Maori. A description of the study site, Lake Moawhitu, follows including a brief summary of its documented history and recent reported observations of its ecological and water quality status. This chapter concludes with an overview of the broader context to the scientific research conducted for this thesis under the Lakes380 research programme.

\subsection{INTRODUCTION TO TUNA}

The freshwater eel, or tuna as it is known to Māori, was until several decades ago found in high abundance in Aotearoa's rivers and lakes. For centuries tuna has permeated Māori culture and lifestyle like no other food source: "A whole cycle of life revolved around gathering and preparing this commodity of food, and it was jealously guarded" (Adkin, 1948). Many marae are adorned with carvings of tuna alongside their tūpuna. The whakapapa of tuna is ancient knowledge, passed down by tūpuna to successive generations. Their whakapapa points to a revered status of tuna which tells of their pre-human arrival through a Te Ao Māori lens. Tuna were heavily relied upon by tūpuna as a source of kai and important events were often scheduled around their harvesting. They are considered as kaitiaki of streams, rivers and lakes; a vehicle for knowledge transmission which educated Māori on tuna's life cycle, habits, and health; and thereby were also used as environmental indicators (Potangaroa 2010).

This research draws from both knowledge streams - biophysical science and mātauranga Māori with respect to whakapapa. Lakes380's intention to partner with iwi, hapū and whānau demonstrated a need to acknowledge manawhenua, their whakapapa, their mātauranga Māori, towards a synthesis and integration of knowledge in the hope of creating new or relevant regenerative strategies. 
As kaitiaki, Māori have an extensive and intimate knowledge of the ecology and sustainability of tuna and have fished tuna without adversely affecting the population. This intergenerational knowledge emerged from observations of their life cycle, habitat needs and migration patterns over generations of time. For several centuries tuna have been an integral part of traditional Māori practices to, for example, provide manaakitanga (the capacity to care and demonstrate hospitality e.g. welcoming and feeding visitors) and koha (gifts).

\subsubsection{ECOLOGY OF TUNA}

Tuna are found at almost all aquatic habitats with access to the sea (Jellyman, 1989). They are long lived and have catadromous lifecycles, spawning and hatching at sea and returning as juveniles to freshwater, developing to adults and returning to the sea to spawn and die (Davey \& Jellyman, 2005). Aotearoa has two endemic tuna species, the short-fin (SF) species (Anguilla australis) and the long-fin (LF) species (Anguilla dieffenbachia) (Graynoth \& Taylor, 2000. Figure 2; Graynoth et al, 2008). These species differ in habitat preference (Glova, Jellyman, \& Bonnett, 1998), diet (Hicks, 1997; Jellyman, 1989), and growth (Chisnall \& Kalish, 1993).

Longfin eel

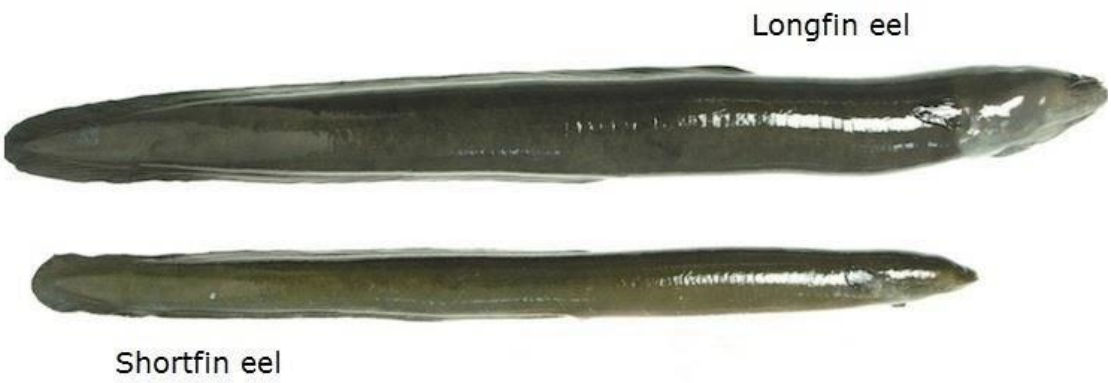

Figure 2 Image comparing characteristics of short-fin and long-fin tuna https://www.sciencelearn.org.nz/images/4

Long-finned tuna are Aotearoa's largest native freshwater fish (Jellyman, 2007), and are regarded by Indigenous Māori as a taonga species. The LF and SF tuna historically dominated Aotearoa waterways, often constituting 90 per cent of the total stream fish biomass (Jellyman, 2007). 
The life cycle of Aotearoa's freshwater tuna comprises five principal stages, identical to all other anguillids (Figure 3). Evidence obtained by satellite tracking suggest that Aotearoa's tuna migrate thousands of kilometers to breed in a region of the southwest Pacific Ocean known as the Tongan Trench (Arai et al, 2004; Jacoby et al, 2015). Both the LF and SF tuna are opportunistic feeders, can consume a wide range of food and have diets that change as they increase with size (Jellyman, 1989).

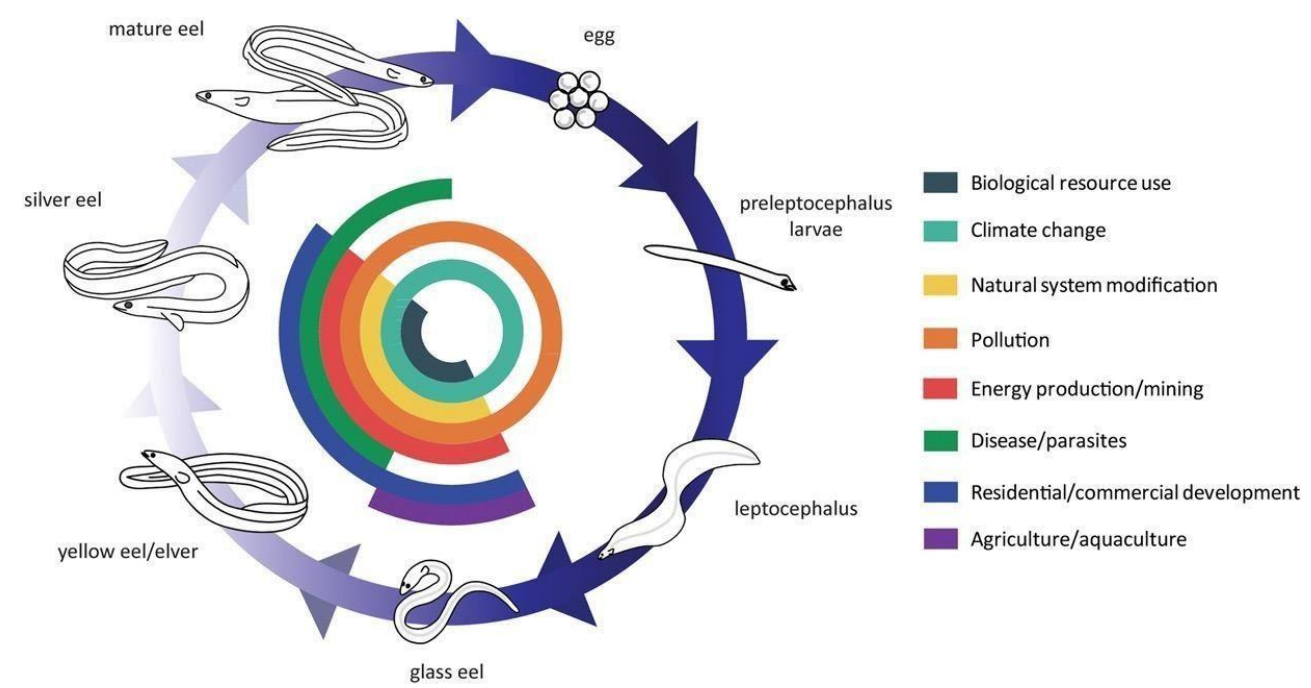

Figure $3 \mathrm{~A}$ schematic diagram of the life cycle of tuna and the possible threats associated with each stage (Jacoby et al, 2015).

Tuna have suffered dramatic declines in population over the past several decades from the pressures of: overexploitation by fisheries, migratory barriers, changing oceanic conditions driven by climate change, disease, parasites, predation and freshwater pollution (Jacoby et al, 2015; August \& Hicks, 2008 Beentjes, Jellyman, \& Kim, 2006; Jellyman, Graynoth, Francis, Chisnall, \& Beentjes, 2000)). A major concern for tuna is the migratory barriers imposed by dams and weirs (Jansen et al, 2007).

Europeans saw tuna as a pest which lead to the exploitation of stocks for trade. The straightening of rivers and draining of wetlands have caused considerable habitat loss. This combined with macrophyte removal, siltation and channelization further reduce the quality of habitat which remain. These impacts on habitat are particularly problematic for larger 
tuna as there is a direct relationship between large tuna and the amount of suitable vegetative cover (Burnet, 1952) implying that tuna prefer some form of surface cover. Forest land cover, however, is estimated to have decreased from $53 \%$ to $23 \%$ of land area from pre to post-European settlement (Burnet, 1952). Given the anthropogenic impacts resulting in significant loss in numbers of large LFs (Long fin tuna), there is now also the concern about the resulting ecological impacts on lower trophic levels (Jellyman, 2007). Fresh water degradation, in particular is thought to have been instrumental in the recent decline, with little sign of this trend abating. In view of these developments in recent decades, there is a pressing need for more information on the distribution of tuna, and information on the presence of historic populations.

\subsection{MĀTAURANGA MĀORI}

\subsubsection{WHAKAPAPA}

A Māori world view prescribes that: tuna are a tuākana (older sibling) to humans; respect for older siblings is expected; tuna were to be offered to humans as a source of food; reciprocity is expected from humans that includes respect for the home of tuna, in other words that unpolluted waters be maintained (Moore, 2013). As discussed in more detail in Chapter 4 (4.3), there are different creation stories for tuna in Aotearoa. One narrative explains that tuna was a child of Te Ihorangi who came from the union of Ranginui and Papatūānuku. Te Ihorangi's children included Ngōiro (the conger eel), Tuere (the blind eel) and tuna.

Tuna have many names depending on their size, colorations, maturity, taste, habitat location/region, among other things. Many iwi also have their own name for certain varieties of tuna such as Hao, Paapaka, Puhi, Riko, Paranui, Kūwharuwharu/Ōrea/Kirirua, Tahimaro, Ruahine, Matamoe, and Kōkopu.

Some examples include:

- Kūwharuwharu/ōrea/kirirua: large variety that can grow up to $2 \mathrm{~m}$ long and weigh about $50 \mathrm{~kg}$.

- Tahimaro: a very large, black tuna; often territorial and sometimes aggressive. 


\subsection{LAKE MOĀWHITU - BACKGROUND AND HISTORY}

Lake Moāwhitu is located on Rangitoto ki te Tonga' (blood-coloured sky to the south; Figure 4), also known as d'Urville Island. Historically, it has been a customary fishing site, which supplied the local iwi, Ngāti Koata with an abundant source of tuna. In the past several decades pastoral land use has severely impacted the condition of the lake and adjacent wetland system, diminishing its ecological value and tuna carrying capacity.

Lake Moāwhitu has an approximate surface area of $0.35 \mathrm{~km}$, and a maximum depth of $14 \mathrm{~m}$. The lake and its associated coastal wetland complex is thought to have been formed by the evolution of coastal sand dunes that blocked an historical river valley draining southward to Greville Harbour. The lake and coastal area has been recorded in Māori history as affected by a tsunami or tidal wave named Tapu-arero-utuutu that devastated the kāinga/village of Moāwhitu it is believed around the 16th century (King et al, 2018; McSaveney, 2006).

Lake Moāwhitu is situated at the end of the catchment in the lowlands which adjoins outstretched flat land to the south. The total lake catchment size is approximately 205 ha (Pätete, 2008). It has undergone significant anthropogenic change since human arrival particularly from deforestation, changes in water levels, and in the past several decades, agricultural intensification. High producing exotic grassland covers $44 \%$ of the lake's catchment. A small stream at the north end of the lake is the main inflow to the lake. At the south eastern end of the lake there is a culvert, which drains water through a complex wetland to an outlet at the far eastern end of a beach facing Greville Harbour. The lake was thought to have been partially drained in 1948 (Pätete, 1997) and as a result today is much smaller in size than prior to this date. Riparian replanting of native vegetation has recently commenced in areas of the lake catchment that were previously farmed (Parai, 2019b - DoC report). 


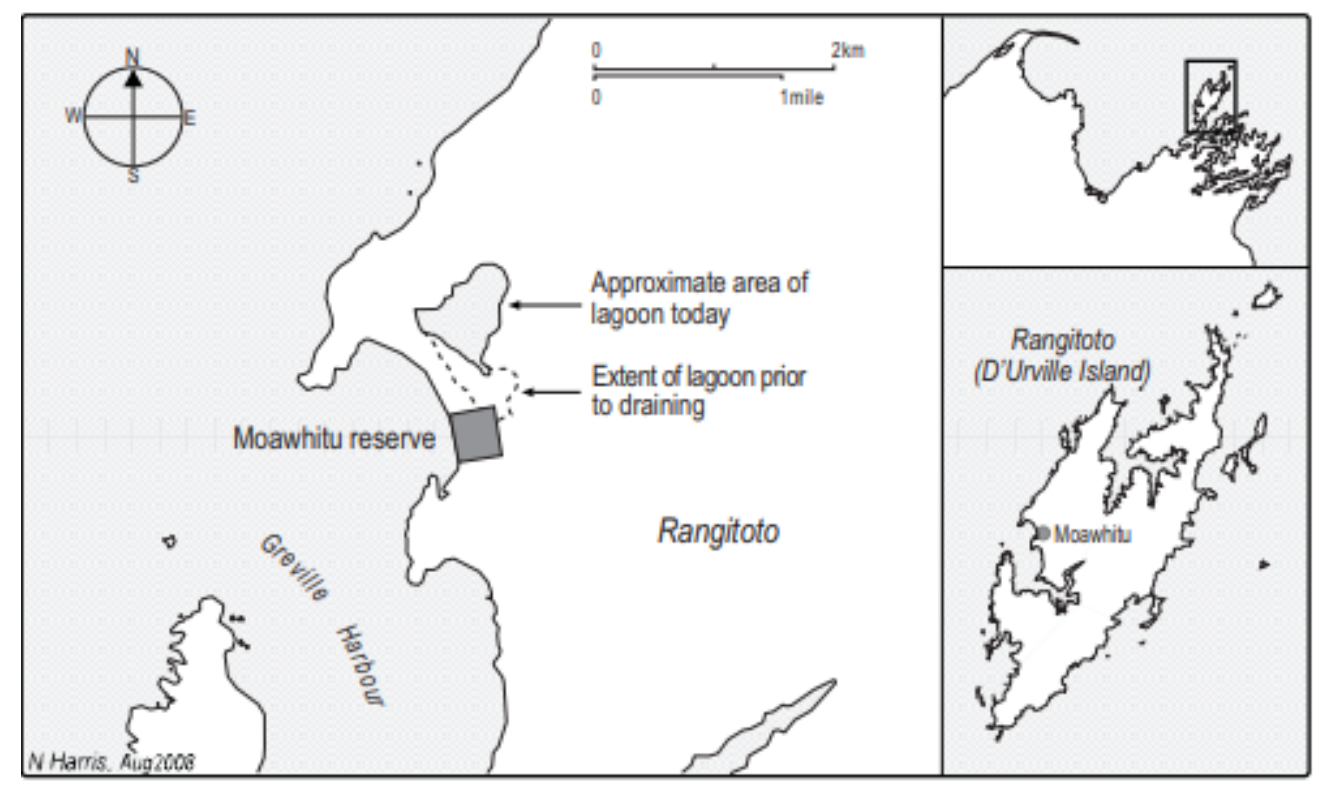

Fig 4: Left: Lake Moāwhitu showing extent of lagoon prior to draining from 1948 and the easement used as access passage by Ngati Koata. Right: Location of Moawhitu on Rangitoto ki te Tonga (bottom) in the northern-most Marlbrough Sounds (top) (Pätete, 1997).

Gazetted in 1976 as a fishing ground for Ngāti Koata, the easement (giving manawhenua legal access to the lake from Greville harbour), was subsequently declared Māori freehold land in 1982 (Pätete, 1997). Recent fisheries surveys conducted by the Department of Conservation (DOC), Ngāti Koata and Cawthron Institute confirm the lake contains Short-finned and Longfinned tuna, common bullies, and the galaxiid species inanga.

\subsubsection{ECOLOGICAL HEALTH OF MOĀWHITU: TRENDS AND ISSUES}

Several reports on the current ecological health of tuna at Lake Moāwhitu were produced by the Department of Conservation (DOC) between 2005 and 2019 (Rutledge, 2005, 2007, 2013; McCaughan, 2014, 2015; Parai, 2019). Additional ecological reports were provided by Cawthron Institute, the most recent being a 2019 water quality report (Kelly, 2019). These form part of a larger project on the restoration of the habitat and freshwater fish populations of the Moāwhitu catchment that has been underway since 2005. The reports predominantly focus on surveys conducted at Lake Moāwhitu and the nearby wetland drain habitat for tuna and native fish populations, and includes assessments of the catchment's freshwater quality (Drinan, 2018), with recommendations for enhancement of tuna stocks. The findings of these studies on freshwater quality are summarised below. 


\subsubsection{WATER QUALITY}

Water quality monitoring in Lake Moāwhitu between 2017 and 2019 showed that concentrations of total phosphorus (TP), total nitrogen (TN), and chlorophyll-a (Chl-a) classified the lake as Hypertrophic. Chlorophyll-a exceeded annual maximum limits of 50 $\mathrm{mg} / \mathrm{m}^{3}$ on five of seven monitoring occasions.

Continuous monitoring of dissolved oxygen in the water column also showed that bottom waters regularly had no oxygen (anoxic) over periods of lake stratification, making deeper waters poorly suited to aquatic life. This anoxic state is thought to cause internal recycling of sediment-bound nutrients into the water column, and is thought to largely drive cyanobacterial and dinoflagellate blooms that occurred in the lake, with relatively low nutrient concentrations ( $<190 \mathrm{mg} / \mathrm{m}^{3} \mathrm{TN},<16 \mathrm{mg} / \mathrm{m}^{3} \mathrm{TP}$ ) of tributary inflows.

Based on recent sampling conducted (Rutledge, 2005, 2007, 2013; McCaughan, 2014, 2015; Parai, 2019) water quality is not improving, possibly due to limited catchment inflows to dilute and flush out nutrients and contaminants (Rutledge, 2013). Due to the small Moāwhitu catchment and therefore limited flushing of fine sediment on the lakebed, these contaminants are expected to persist (Rutledge, 2013).

From these recent observations, Lake Moāwhitu water quality is considered to be selfreinforcing through a cycle of algal blooms driving internal nutrient recycling. Increasing dissolved oxygen in the lake bottom waters (through lake aeration) or binding mobile nutrients in sediments (by sediment capping) are likely to be required to reduce or cease algal blooms and improve water quality (Kelly et al, 2019).

\subsection{LAKES 380}

My thesis is part of a five-year research project known as Our Lakes' Health: past, present, future, or Lakes380 (www.lakes380.com). The project aims to enrich knowledge on the environmental, social and cultural histories of about $10 \%$ of New Zealand's 3,800 lakes. This involves collecting and analyzing lake sediments and water samples, as well as interviews and field visits. 
Of the 3,800 Aotearoa's lakes that are over one hectare in size, there is scientific data on less than $2 \%$ of these lakes. This small percentage of data captured from such monitoring programs only relate to the past $10-30$ years. As such there is no information on lake health and, by extension its connection to tuna populations prior to human arrival.

Lake sediments are natural archives that continuously record environmental history. By collecting and analysing sediment cores the environmental history of a lake can be reconstructed. In this thesis I document the sampling that has been conducted at Lake Moāwhitu, the suite of analyses that have been applied to these samples, and then discuss the results and what they mean in relation to the restorative value this presents for Lake Moāwhitu, manawhenua and stakeholders. The data to reconstruct the environmental history of Moāwhitu (hyperspectral scanning, bacterial DNA, pollen), were provided by the Lakes380 team. 


\section{CHAPTER 3 - BIOPHYSICAL DATA AND TUNA EDNA}

\subsection{INTRODUCTION}

Aotearoa's freshwater quality, particularly in lowland lakes and rivers, is declining (Our Fresh Water, 2017) with damaging consequences for the organisms that live in these habitats. Understanding the current and historic biodiversity of Aotearoa's Lakes is essential to assist in protection from further damage and to guide effective restoration. Lake Moāwhitu is an example of a lake which has experienced significant water quality degradation impacting its ecological biodiversity, however providing informed restorative solutions is problematic given the lack of long-term monitoring data (Parai, 2019). To provide this historic context, this study uses paleolimnology to provide insights into lake health and vegetation in the surrounding catchment over the last $\sim 1000$ years or so. Paleolimnology stems from limnology and paleoecology and provides a useful approach to study historic shifts in water quality and biological structure and functioning. It utilizes biophysical information i.e. proxies (such as pollen) preserved in lake sediment profiles to reconstruct past environments, specifically changes in littoral and lacustrine communities and in regional vegetation within the catchment over time and their possible linkages. This in turn can provide insight into past ecological reference states, allowing the current condition to be compared to pre-human and early human settlement conditions towards an understanding into the impact of recent human activity on tuna populations (Parai, 2019).

The objective of this part of the thesis was to use a range of biophysical proxies to analyse a sediment core taken from Lake Moāwhitu to develop an environmental reconstruction for the lake and its catchment.

\subsection{TUNA POPULATIONS AT LAKE MOĀWHITU}

For centuries the tuna populations at lake Moāwhitu were healthy and abundant (Bassett and Kay, 1999). However, the conversion of wetlands to pastoral use in the 1940s had a significant impact on habitat quantity and quality for tuna. This is highlighted by the summarised DoC reports which consolidates catch surveys conducted at Lake Moāwhitu and the adjacent wetland drain habitat for tuna and native fish populations (Parai, 2019-b). Similarly, recent 
ecological assessments by Cawthron Institute have focussed on the catchment's freshwater quality (Kelly, 2019).

Rutledge (2013) reported that the highest density and quality of longfin tuna occurred in the main outlet drain, which was associated with heavy cover provided by large logs and a bridge (Fig 5).

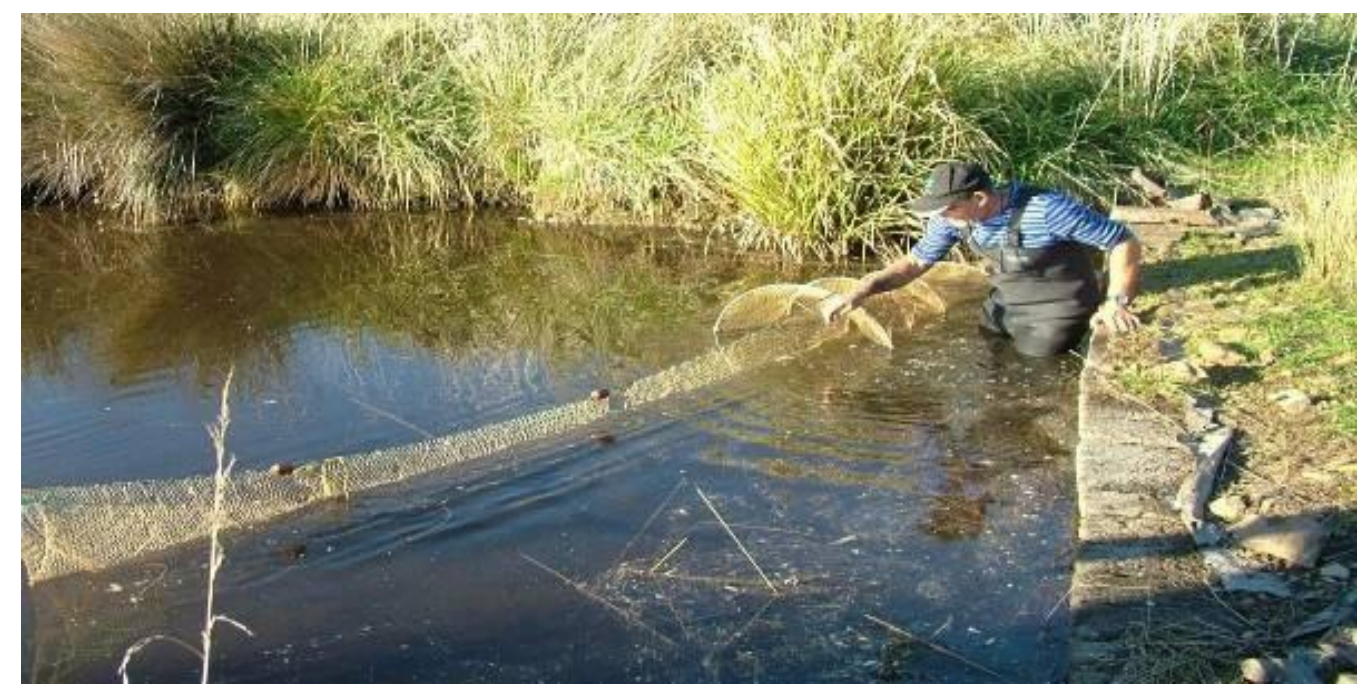

Figure.5: More longfins are observed where bridges provide cover in the drains (photo taken in 2018)

Further, the highest density and quality of longfin found in the lake was near the heavy rush cover (Figure 6) illustrating the importance of cover for the larger longfins.

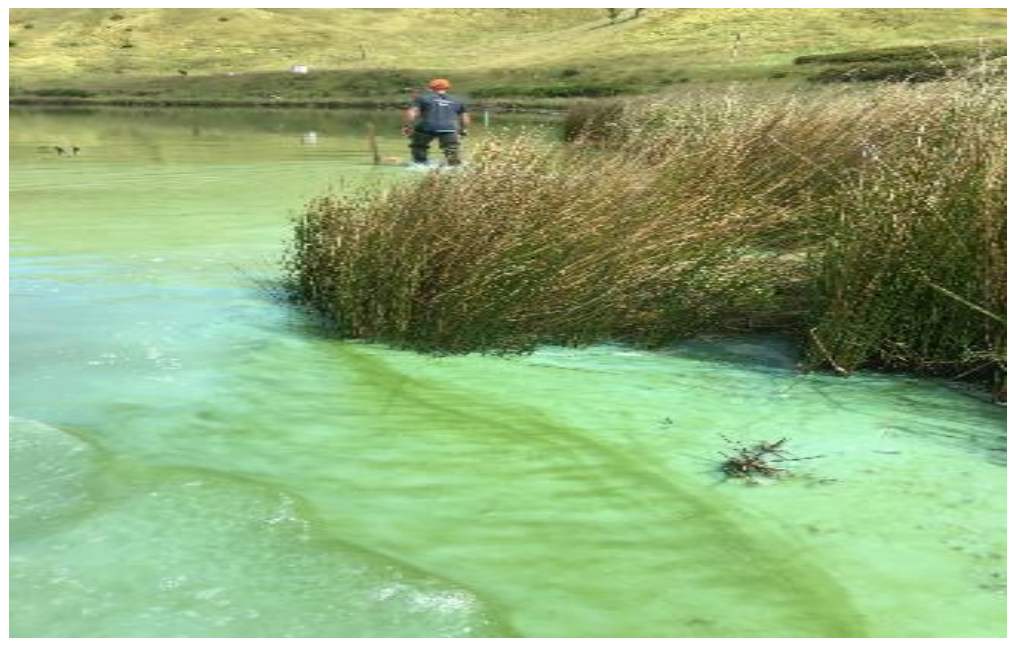

Figure 6. Rush cover around fringe edges in Lake Moāwhitu, December 2018. 
Based on the DoC catch surveys, the tuna population in the lake was thought to comprise $65 \%$ longfin tuna and $35 \%$ shortfin, while in the drains (wetlands) approximately $90 \%$ of tuna observed were longfin (Rutledge 2013). However, since 2008, the tuna catch data (catch rates, weights, and sizes) signify an at-risk tuna population that is reflective of the national trend with declining runs and disproportionately low numbers of elvers and small size classes of eels (Jellyman, 2009). According to manawhenua, Ngāti Koata, low catch rates were caused by both pastoral land use and commercial scale harvesting (Tahua Rene, pers. comm, see also Chapter 4, Section 4.5.4), consistent with the reports described above.

These survey findings point to a need to gain deeper historical insight into these more recent environmental impacts.

\subsection{PALEOLIMNOLOGICAL PROXIES USED IN THIS STUDY}

The subsections below provide a brief introduction to each of the different paleolimnological proxies analysed in this thesis, and what information these can provide about the history of the lake and surrounding catchment.

\subsubsection{Pollen ANALYSIS For VEgetation RECONSTRUCtion AND CHRONOLOGY}

Pollen analysis uses fossilized pollen and spore assemblages in sediments for the purpose of reconstructing past vegetation and environments (Newnham et al, 2018). As the outer coat of a pollen grain or spore is quite resistant to chemical and physical degradation, they are typically well-preserved in the anaerobic conditions under which lake sedimentary sequences develop. Reconstructing past vegetation communities from fossil pollen assemblages preserved in lake sediments is complicated by taphonomic factors, whereby pollen is transported by wind or water from unknown sources. Vast differences in pollen production and dispersal between plants also complicate these reconstructions. In particular, insect- and bird-pollinated species such as Phormium tenax (harakeke) tend to be under-represented in pollen assemblages whilst wind-pollinated species such as Dacrydium cupressinum (rimu) tend to be over-represented.

A robust chronology for the Lake Moāwhitu sediment core was not available at the time of writing this thesis. However, vegetation reconstruction from the pollen record enabled 
identification of broad level historical phases to be identified with indicative ages based on radiocarbon-dated pollen and archeological records from elsewhere in New Zealand (e.g., McGlone et al., 1983; Anderson, 1991; McGlone \& Wilmshurst, 1999; Wilmshurst et al., 2008; McWethy et al., 2009). With reference to this previous work, in this study pollen and charcoal data were used to assign specific time periods as follows: Pre-Human (PH), Evidence of Māori Settlement (EMS) from c. 800 years BP and Post-European Settlement (PES; c. 1840) phase. The main markers for the start of the EMS were sustained increase in charcoal and bracken fern spores combined with sustained loss of forest tree pollen, which are widely used indicators of landscape disturbance accompanying human settlement in New Zealand (McGlone et al., 1983). The primary indicator for the start of the PES phase was the appearance of exotic plant pollens such as the Monterey pine (Pinus radiata) and sheep's sorrel (Rumex acetosella).

This palynologically-defined chronological framework was also applied to the other proxy records (discussed below) to enable changing water quality indicators to be evaluated in the context of land use change.

\subsubsection{HYPERSPECTRAL SCANNING}

Hyperspectral imaging spectrometry is a high-resolution, non-destructive technique that scans the surface of a sediment core and obtains reflectance spectra in the visual to nearinfrared range. The outputs are analysed to identify changes in the concentration of a range of constituents in the lake sediments. For this study, hyperspectral imaging was used to derive the Relative absorption band depth (RABD) at 660-670 nm as a proxy for Chlorophyll a and inlake plant productivity. The Moāwhitu data were provided by the Lakes380 team.

\subsubsection{ENVIRONMENTAL DNA}

Environmental DNA (eDNA) in aquatic systems refers to the genetic material released by organisms in the form of tissue slough, cell lysis, gametes, excretion and saliva, among other secretions (Sassoubre et al., 2016; Taberlet et al. 2018). Environmental DNA can be extracted from living organisms if it is still contained in a cell, but also following death when it is 'free' floating or bound to organic or inorganic particles (Cristescu and Hebert, 2018). The discovery that aquatic sediments contain DNA archives that preserve genetic information on organisms that once lived there provides enormous potential for gaining insights into how past environmental changes have impacted aquatic species. One of the most significant 
advancements is that soft bodied organisms, which don't leave fossils in sediment, can now be analysed (Domaizon et al., 2017; Keck et al. 2020).

A number of different molecular methodologies can be used for environmental DNA analysis. In this thesis metabarcoding was used.

\subsubsection{METABARCODING}

Metabarcoding has become a well-established method for characterising the biodiversity of biological communities in different types of environmental samples (Chariton et al., 2010; Fonseca et al., 2010 ; Zaiko et al. 2020; Darling et al. 2020). It enables the rapid identification of a species by matching short gene fragments (which is generated from High Throughput Sequencing) to a DNA sequence reference library, which is usually generated from morphologically verified specimens (Hajibabaei et al. 2011; Taberlet et al. 2012). Depending on the primers used in the PCR, it is possible to target a specific or wide range of organisms. In this thesis metabarcoding is used to explore the microbial communities. Bacteria are at the base of lake food webs as primary producers and perform many biogeochemical functions, such as methane, sulphur and nitrogen metabolism. Assessing how their community composition changes can provide insights into key shifts in water quality within a lake.

As noted in the general introduction, during my summer internships I was involved in the development of two molecular assays that specifically detects tuna in environmental samples (Parai, 2019). I had also aimed to apply these assays to the Lake Moāwhitu core samples to characterize historic tuna population in the lake. Covid-19 impacts and methodological challenges associated with extracting enough DNA from the core samples meant this was not possible during the time frame of my Masters. Below, I describe the basics of the assay - a manuscript documenting the assay developed and validation, of which I am a co-author, has recently been submitted (Thomas-Laing et al, 2020).

The tuna assays were developed to be run on a technology known as droplet digital PCR. Digital Droplet PCR is a relatively new method that involves each sample of target DNA being fractionated into approximately 20,000 droplets, and PCR amplification of the template molecules occurs in each individual droplet. This removes many of the standards, eliminating 
biases and mismatching including repeatability and reproducibility whilst increasing the capacity to measure multiple targets in one analysis (Thompson-Laing et al, 2020). Through my summer internship research and then further work by collaborators at Cawthron we successfully developed species-specific ddPCR assays to detect $A$. dieffenbachii and $A$. australis DNA in both water and sediment samples (Parai, 2018). The assays used primers and probes designed in regions of the mitochondrial cytochrome $b$ and 165 ribosomal RNA genes for A. dieffenbachii and A. australis, respectively. Eleven river water samples were analysed by metabarcoding (using fish specific primers) and were compared with the ddPCR assays. The presence of $A$. dieffenbachii and $A$. australis DNA was detected in a greater number of water samples using ddPCR in comparison to metabarcoding. Detection of eel eDNA in surface sediment samples was more consistent in lake sediments compared to river sediments. Further work is required to apply these assays to down core samples.

\subsection{Material AND Methods}

\subsubsection{SAMPLING AND LABORATORY ANALYSIS}

\section{Core collection and subsampling}

Four sediment cores were collected from the lake using a Uwitec gravity corer with a $90 \mathrm{~mm}$ PVC barrel, from a $4 \mathrm{~m}$ long inflatable boat. Cores are collected at the deepest point and kept chilled in darkness until subsampling. Two cores were selected for subsampling while the other two were archived for future use. In the laboratory, the cores were split in half, photographed, and logged in detail. Slices of the half-cores were sampled at various depths.

For pollen analysis an approximate $2 \mathrm{~g}$ subsample was collected in a plastic tube, then stored at $4^{\circ} \mathrm{C}$ until analysis.

For DNA, the top 2-3 mm of the sediment was carefully scraped away using a sterile spatula to remove any contamination that may have occurred during the core splitting process. Approximately $2 \mathrm{~g}$ of sediment was collected using a sterile scoop which was placed in a sterile bag and stored frozen $\left(-20^{\circ} \mathrm{C}\right)$ until DNA extraction. 


\subsubsection{Pollen ANALYSIS}

Preparation of pollen slides followed standard procedure (Faegri et al., 1989). Approximately $0.25 \mathrm{~mL}$ of the sample was added to a polypropylene vial $(1 \mathrm{~mL})$ with $0.5 \mathrm{ml}$ of water. Carbonate was removed from the sample using a 10\% hydrochloric acid wash for $25 \mathrm{~min}$. The organic compounds were then broken down using a glacial acetic acid/sulphuric acid wash before being filtered through $6 \mu \mathrm{m}$ nylon mesh. Two slides were made using a $22 \mathrm{~mm} \times 22$ $\mathrm{mm}$ cover slips. Coloured jelly was added to the slide to highlight the cell walls to assist with sample analysis.

\subsubsection{HYPERSPECTRAL ANALYSIS}

Hyperspectral imaging was used to derive the RABD at 660-680 $\mathrm{nm}$ as a proxy for the in-lake productivity for Chlorophyll-a. Cores were prepared by scraping the surface sediment ensuring a smooth and flat surface. This guaranteed there were no pockets or deviations within the surface as these can create false readings within the hyperspectral data. Hyperspectral imaging scans were then collected for each of the four sediment cores using a Specim SISU single core scanner with a SCMOS-50-V10E spectral camera. Image preprocessing and normalization followed that by Butz et al. (2017). Spatial resolution was set to $1 \mathrm{~mm} /$ pixel. Spectral indices were calculated in $\mathrm{R}$ version 3.4.0, with the RABD ratio R660/R670 providing a simple estimate of changes in lake productivity abundance down core.

\subsubsection{DNA EXTRACTION}

Each step of the molecular analysis (i.e. DNA extraction, PCR or ddPCR set-up and analyses, metabarcoding sequencing library preparation) were conducted in separate sterile laboratories dedicated to that step, with sequential workflow to ensure no crosscontamination. Rooms dedicated to DNA extraction, amplification set-up and template addition were equipped with ultra-violet sterilisation which was switched on for a minimum of 15 minutes before and after each use. The PCR set-up and template addition was always undertaken in laminar flow cabinets with HEPA filtration. Aerosols barrier tips (Axygen, USA for PCR or were used throughout.

Approximately $0.25 \mathrm{~g}$ of sediment from each sediment core layer were weighed in the first tube of a DNEasy ${ }^{\circledR}$ PowerSoil ${ }^{\circledR}$ Soil DNA Isolation Kit (QIAGEN, USA). DNA was then extracted following the protocol from the manufacturer, with DNA eluted in $100 \mu \mathrm{L}$. Extraction of DNA 
was performed in batches of eight to ten samples including a negative control every two batches. This contained all the reagents but no sediment. DNA concentrations and quality (were measured using a BioSpectrophotometer (Eppendorf AG, Hamburg, Germany).

\subsubsection{BACTERIAL METABARCODING}

The V3-V4 region of the bacterial 16S rRNA gene was amplified by PCR using the bacterial specific primers 341F: 5'-CCT ACG GGN GGC WGC AG-3' and 805R: 5'-GAC TAC HVG GGT ATC TAA TCC-3' (Klindworth et al., 2013). The primers included Illumina ${ }^{\text {TM }}$ overhang adapters to allow dual indexing as described in (Kozich, Westcott, Baxter, Highlander, \& Schloss, 2013). Triplicate PCR reactions were undertaken on each sample in $20 \mu \mathrm{L}$ volumes. The reaction mixture consisted of $10 \mu \mathrm{L}$ of MiFi $2 \times$ PCR mastermix, $2 \mu \mathrm{M}$ of each primer (final conc.) and $2 \mu \mathrm{L}$ of template DNA. Cycling conditions were an initial $1 \mathrm{~min}$ at $94^{\circ} \mathrm{C}$ before 30 cycles of $95^{\circ} \mathrm{C}$ for $15 \mathrm{~s}, 52^{\circ} \mathrm{C}$ for $15 \mathrm{~s}, 72^{\circ} \mathrm{C}$ for $15 \mathrm{~s}$, with a final extension step at $72^{\circ} \mathrm{C}$ for $7 \mathrm{~min}$. Negative PCR controls were run alongside the samples. The triplicate PCR replicates were pooled and $20 \mu \mathrm{L}$ was cleaned and normalized using SequalPrep Normalization plates (ThermoFisher Scientific, USA), resulting in a concentration of $\sim 1 \mathrm{ng} \mathrm{LL}^{-1}$. The cleaned samples were sent to Auckland Genomics Facility for paired-end ( $2 \times 250$ bp) sequencing on an Illumina Miseq ${ }^{\mathrm{TM}}$ platform. Sequence libraries were prepared as detailed in the Illumina 165 metagenomics library prep manual. One deviation from the protocol was that after the indexing PCR, $5 \mathrm{~mL}$ of each sample were pooled and clean-up was undertaken on the pooled library instead of samples being individually cleaned. The concentration and quality of the library was quantified using a bio analyzer. The library was diluted to $4 \mathrm{nM}$ and denatured and a $15 \%$ PhiX spike in added. The library was further diluted to a final loading concentration of $7 \mathrm{rM}$.

Primers were removed from the raw reads with cutadapt (Martin, 2011) allowing one mismatch. Sequences without primer sequences were discarded. Remaining sequences were processed with DADA2 (Callahan et al., 2016) within the R framework (Team, 2014). Forward reads were truncated to $230 \mathrm{bp}$ while reverse reads were truncated to $228 \mathrm{bp}$. The number of allowed maximum "expected errors" (maxEE) was two and four for the forward and reverse respectively. The first $10^{8} \mathrm{bp}$ were used to construct a parametric error matrix. Sequences are de-replicated and amplicon sequence variants (ASVs) were inferred based on this error matrix. After inference singletons were discarded and remaining reads were merged with a 
maximum of $1 \mathrm{bp}$ mismatch and a required minimum overlap of $10 \mathrm{bp}$. Chimeric sequences were removed from the analysis using the removeBimeraDenovo function within DADA2.

The resulting ASVs were taxonomically classified in DADA2 using the rdp classifier (Wang, Garrity, Tiedje, \& Cole, 2007) against the SILVA 132 (Pruesse et al., 2007) database with a bootstrap of 70. The results were combined into a phyloseq object (McMurdie \& Holmes, 2013) and any ASVs classified as eukaryotes, chloroplasts or mitochondria were removed Negative controls were assessed and read numbers for ASVs found in the negative blanks were removed via subtraction.

\subsubsection{MicRobial FunCtional TRAITS}

Microbial community functions were assessed using the metabolic inference pipeline PAPRICA (Bowman \& Ducklow, 2015). Reference sequences for each ASV were converted to fasta files and re-replicated to match their abundance in each sample. These were run through PAPRICA, where the sequences were compared to functional 16S rRNA gene reference genomes and assigned the most likely consensus genome - from this, predicted enzymes (EC numbers; https://www.brenda-enzymes.org/index.php) and their abundances were assigned to each sample. The resulting enzyme libraries were merged into a phyloseq object and compositional relationships investigated. Three key enzyme pathways that changed marked between the time periods were selected and plotted.

\subsubsection{DATA/STATISTICAL ANALYSIS}

Microbial 16S rRNA sequences were standardised to a sampling depth of 9,100 reads (without replacement). Multivariate analysis was undertaken on the samples using Bray Curtis dissimilarity matrices. Non-metric multidimensional scaling (nMDS) was used to visualize the community structure. Statistical differences in the taxonomic composition of the microbial communities between time periods were tested via permutational multivariate analysis using the adonis function within the vegan package of $R$. 


\subsection{RESULTS}

3.5.1 SEDIMENT CORE DESCRIPTION

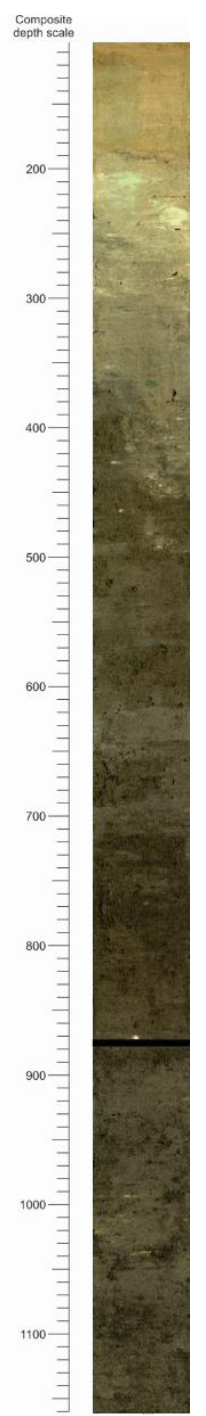

Figure 7 Photograph of Lake Moāwhitu sediment core split in half lengthways. Depth scale is in $\mathrm{mm}$. Note that the top of the core is shown as $11-12 \mathrm{~cm}$ due to the insertion of a core plug in the field.

The sediment core was $117 \mathrm{~cm}$ in length. At the top of the Moāwhitu core light yellow/brown sediment was observed. Following this there is a distinct transition at the $14 \mathrm{~cm}$ mark to a light green down the core until 32-34 cm where a shift into a deeper green/grey peaty layer occurs through to the base of the core (Fig 7). 


\subsubsection{POLLEN RECORD}

The results of down-core pollen analysis are shown in Figure 8. The basis for describing a pollen record is the recognition of assemblages or zones, usually from the percentages of the taxa, as is the case here. Zonation of specific assemblages may in-turn provide reference states for pre and post human arrival, specifically Māori and European arrival. The following paragraphs describe the most notable changes in each pollen zone highlighting the most abundant taxa.

Moāwhitu Pollen Zone One (105-68 cm cal. Yr BP) is characterized by high levels of Fuscospora (30-40\%), Podocarpus (25-5\%) and Prumnopitys taxifolia (20-5\%). Fuscospora levels gradually increase throughout the zone, whilst Podocarpus and Prumnopitys maintain a consistent presence before decreasing abruptly just above the $70 \mathrm{~cm}$ zone. Dacrydium cupressinum pollen maintains a relatively consistent presence $(\sim 10 \%)$ throughout this zone.

Moāwhitu Pollen Zone Two (68 - $33 \mathrm{~cm}$ cal. Yr BP) assemblages feature Pteridium esculentum, Typha, and Poaceae. The zone starts with a rapid increase in Pteridium (ranging from $5-25 \%$ up-core) and peaking at $45 \%$ at the $65 \mathrm{~cm}$ mark. There is also a marked emergence of Typha (5-25\% up-core) peaking at 30\% at the $47 \mathrm{~cm}$ mark. The same trend holds true for the native grasses Poaceae (ranging from 0-35\% up-core) peaking at $35 \%$ at $40 \mathrm{~cm}$ in the core. A similar increase occurs with Cyperaceae. Both Coprosma and Pseudopanex (small trees/shrubs) exhibits a notable increase through this zone before it tapers off up-core. Podacarpus spp. virtually disappears from the record during this interval, which holds true for the remaining tall trees in this zone, the exception being Fuscospora which increases to 55\% at $50 \mathrm{~cm}$ before tapering off up-core to $40 \mathrm{~cm}$. Interestingly, charcoal appears in the core ranging from $0-90 \%$ from the $70 \mathrm{~cm}$ mark up the core.

Moāwhitu Pollen Zone Three (33-0 cm cal. Yr BP) is dominated by Pinus increasing from 0$35 \%$ and peaking at $35 \%$ at $12 \mathrm{~cm}$. Poaceae continues to maintain a strong presence throughout this zone ranging from $35 \%$ - $47 \%$ up to present day. Taraxacum follows Poaceae averaging a $10 \%$ presence in this zone. Notably Pteridium esculentum and Typha decrease significantly, virtually disappearing in this zone, while Myriophyllum makes a late surge, rising to $\sim 6 \%$. 


\section{Pollen Diagram - 1,000 year vegetative history of Lake Moāwhitu catchment}

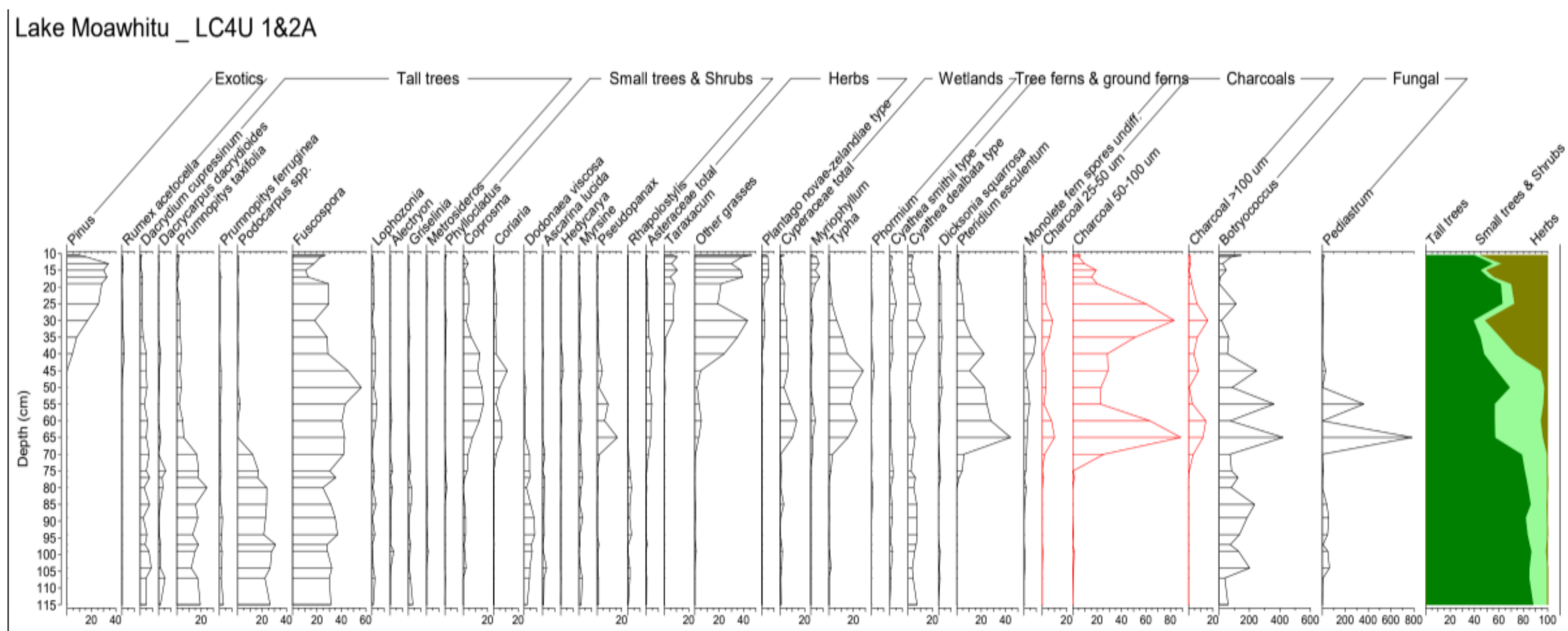

Figure 8 Lake Moāwhitu percentage pollen diagram. Pollen and fern spore curves are percentages of the total pollen sum. Charcoal curves are number of charcoal shards observed per sample. 
The vegetation reconstruction from the pollen record has enabled the identification of these broad-level historical phases that correspond to the pollen zonation:

Pre human Era (Zone 1): 68 to $105 \mathrm{~cm}$. At the base of the Moāwhitu core, the pollen is characterized by Podocarp/Beech forest with tree fern understory.

Maori Era (Zone 2): At $~ 33$ to $68 \mathrm{~cm}$ the sediment is characterized by a reduction in Podocarp forest and increases in shrub species. Increases in bracken fern, charcoal (indicative of burning and landscape clearance), some grass (Poaceae), sedges Cyperaceae and the first occurrence of Typha (Rāupo), indicative of wetland ecology. European Era (Zone 3): 0 to $33 \mathrm{~cm}$. Characterized by Pine (Pinus) pollen, Grasses, Taraxacum (Dandelion types) and charcoal, and a reduction in bracken fern. This is indicative of farming on the island.

Further elaboration for attributing these historical phases is provided in the Discussion section below. They are introduced here to provide a broad historical and land use framework for presenting the results from hyperspectral scanning and eDNA analysis. 


\subsubsection{HYPERSPECTRAL IMAGING}

The relative absorption band of $660 / 670 \mathrm{~nm}$ generated from the hyperspectral scan was used as a measure of lake productivity. For plotting, the data were averaged across $1 \mathrm{~cm}$ to minimise noise (Figure 9). The mean index over the entire record was 1.079. The mean (1.068) $660 / 670$ RABD index was on or below the overall mean for the duration of the PH phase and the first section of the EMS phase. At approximately $50 \mathrm{~cm}$ depth, there is a marked increase in the index which lasted for approximately $10 \mathrm{~cm}$ (mean 1.115 between 35 to $45 \mathrm{~cm}$ ). During the PES phase, the index decreased at $30 \mathrm{~cm}$ and again at $14 \mathrm{~cm}$. The index then rose sharply from $5 \mathrm{~cm}$, peaking at $3.6 \mathrm{~cm}(1.160)$ and at the surface $(0 \mathrm{~cm} ; 1.210)$.

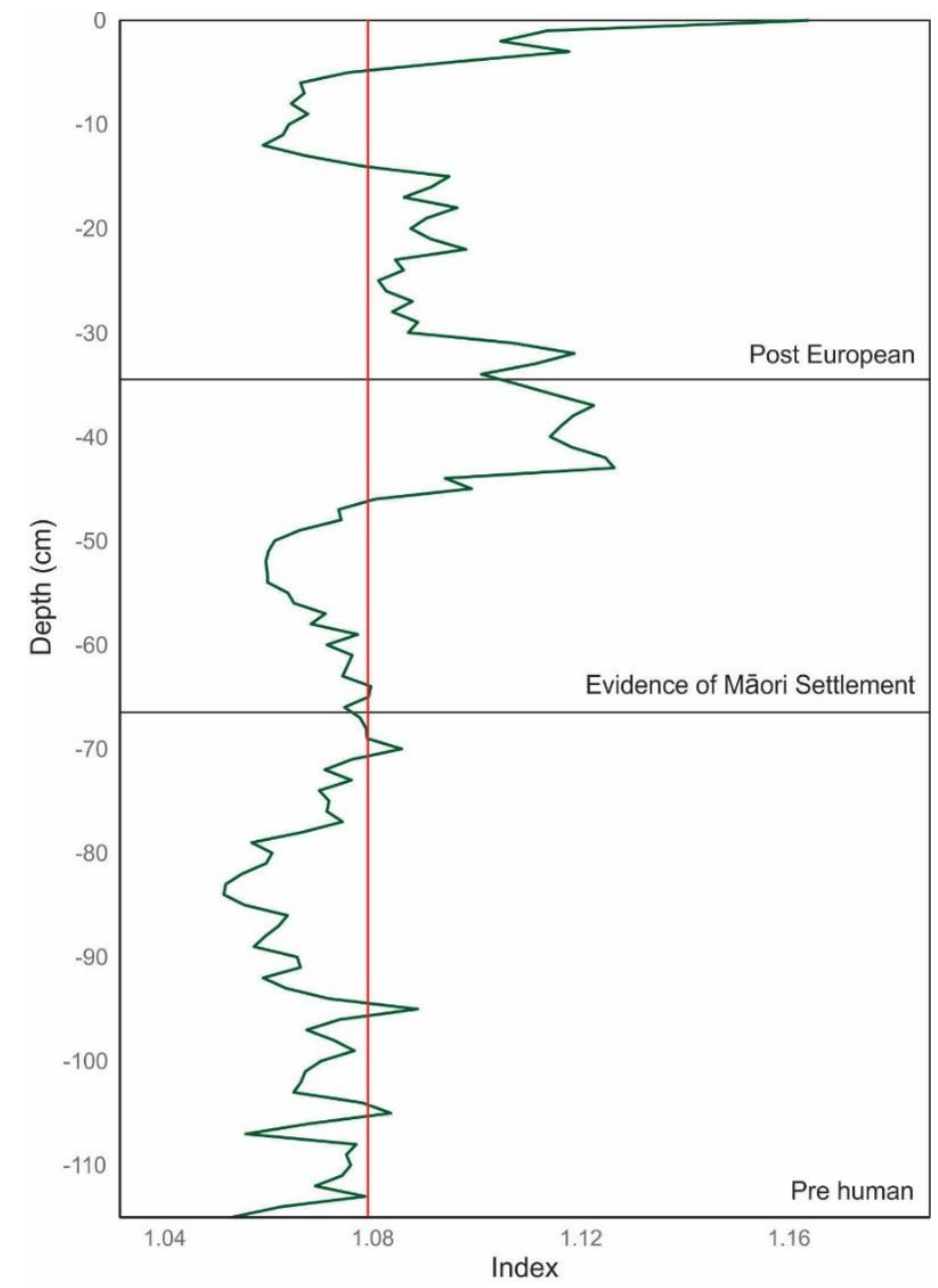

Figure 9. Hyperspectral ratio of the $660 / 670 \mathrm{~nm}$ band (green) in Lake Moāwhitu with mean value of 1.068 shown (red). Vertical lines signal the start/end of the time periods. 


\subsubsection{BACTERIAL COMMUNITY COMPOSITION}

Following quality control, a total of 20,357 bacterial ASVs were recovered from the 27 samples. In general, the number of ASVs reduced with depth, although over 1000 ASVs were still recorded in the deepest sample $(74 \mathrm{~cm})$. The highest number of ASVs was recorded in the $8 \mathrm{~cm}$ sample.

The dominant bacteria class remained relatively constant in the $\mathrm{PH}$ and EMS phases with Dehalococcoidia most abundant, followed by Bathyarchaeleia, Anaerolineae and several unclassified bacteria (Figure 10). There was gradual shift in composition during the PES phase. This becomes most notable from $8 \mathrm{~cm}$ upwards, with Gammaproteobacteria becoming the most abundant Class and Verrucomicrobiae also increasing notably. Among the Gammaproteobacteria, the two most abundant ASVs, that were only present in very low abundance in the EMS phase, were from genera Dechloromonas, and Family Arenicellaceae (unknown genera).

Bacterial taxa identified at Lake Moāwhitu
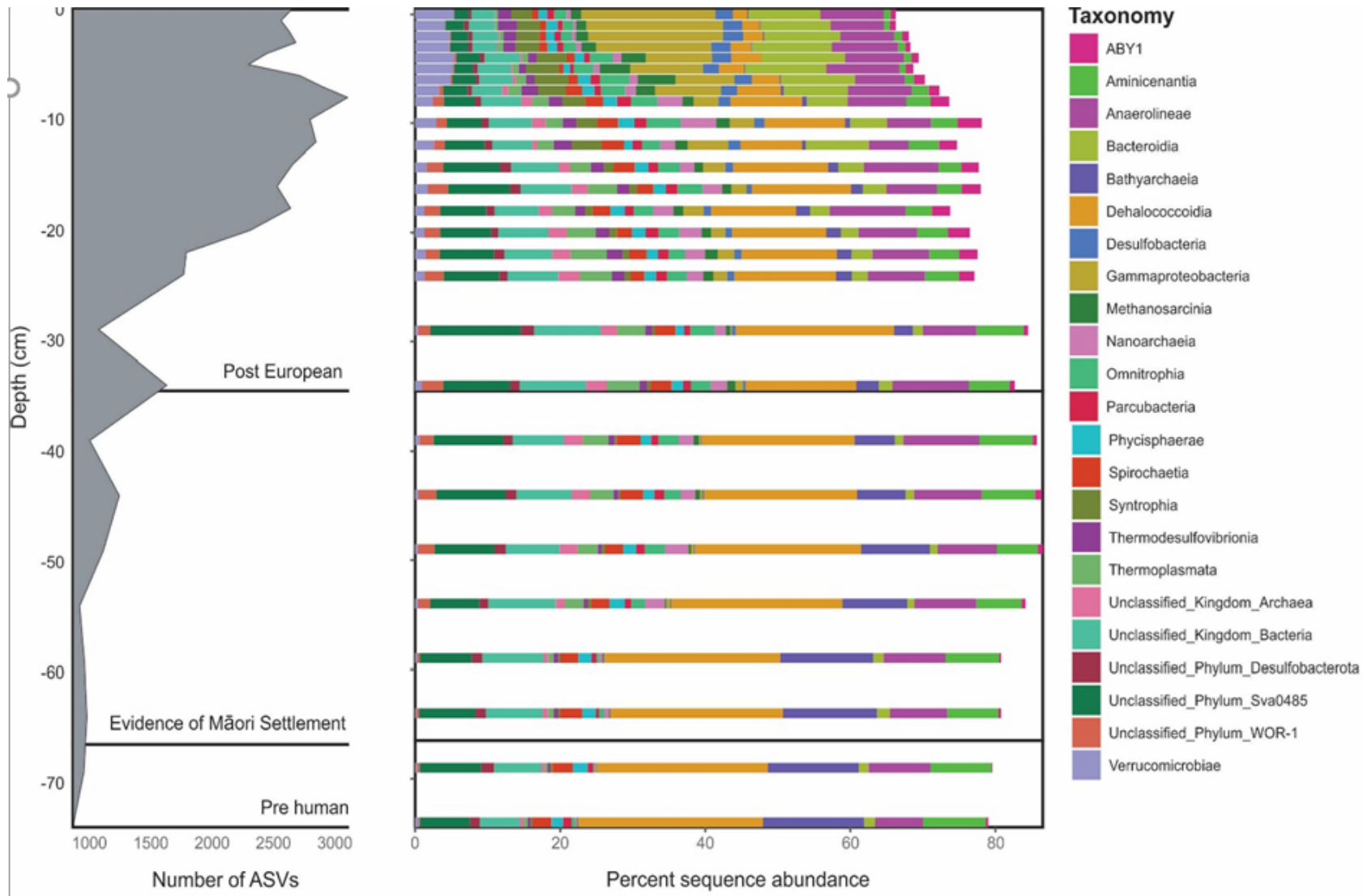

Figure 10. Left panel: number of amplicon sequence variants (i.e. richness); Right panel (including key): Percent sequence abundance at the Class level. 
Non-Metric Multi-dimensional Plot

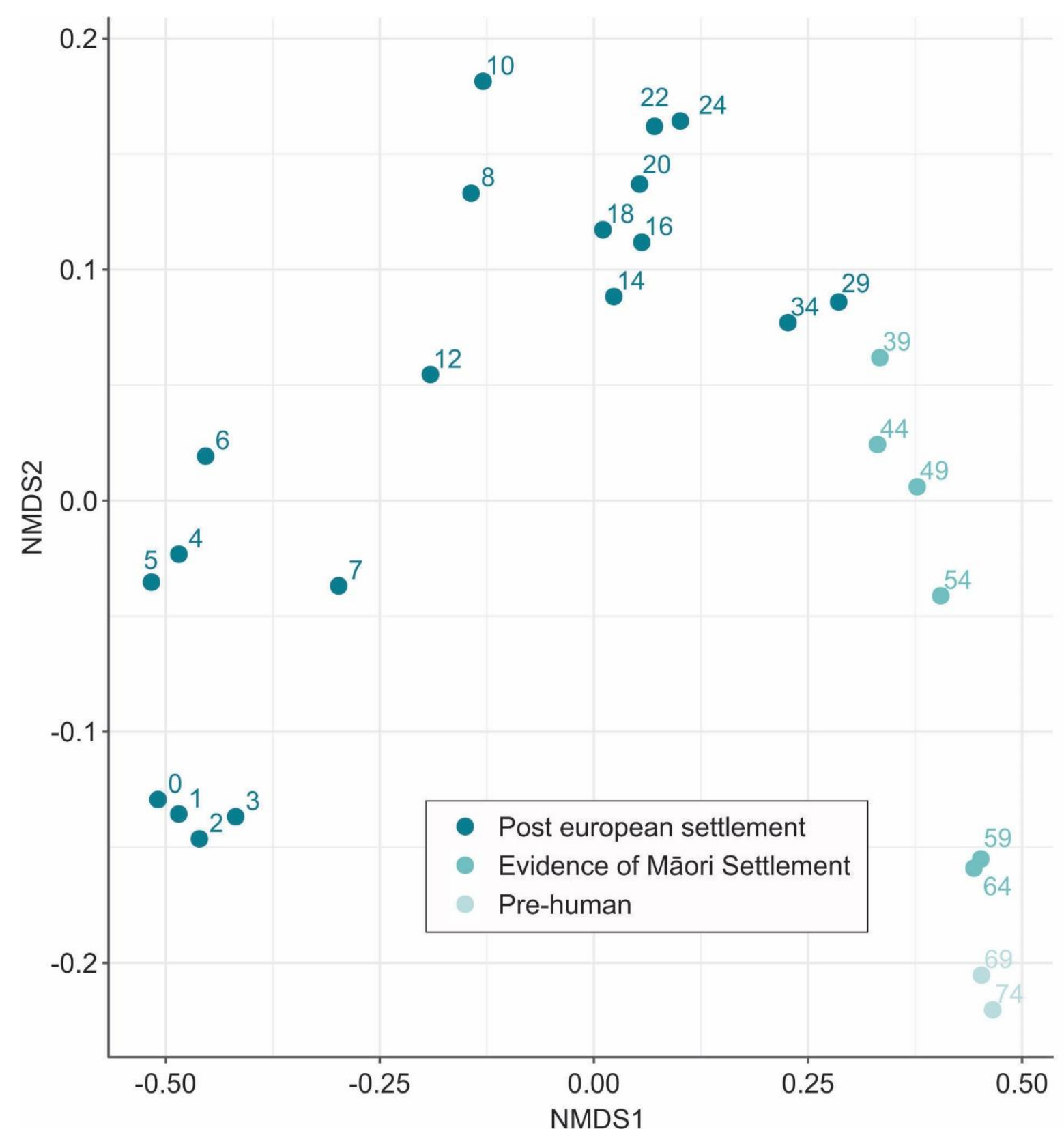

Figure 11. Non-metric multidimensional scaling (NMDS) plot based on Bray Curtis distance matrices for Lake Moāwhitu bacterial eDNA samples grouped by the three historical phases. Depth $(\mathrm{cm})$ of each sample is given next to each point. 
The non-metric multidimensional (NMDS) plot compares the community composition and structure of each sample to all other samples to infer how similar the communities are to one another; the closer they cluster the more similar they are. The NMDS shows a shift in the bacterial community composition over time (Figure 11). Samples from the PH phase and two samples $(59$ and $64 \mathrm{~cm}$ ) from the EMS clustered together. The other samples from the EMS phase (39-54) were more closely clustered with deeper samples (29 and $34 \mathrm{~cm}$ ) from the PES phase. Among the samples from the PES phase, there were two loose clusters $(8-34 \mathrm{~cm}$ and 4-7 cm) and two tighter clusters $(29-34$ and $0-3 \mathrm{~cm})$. Adonis analysis showed that the community composition between the phases was significantly different $(F=5.8579, p<0.001)$. Pairwise tests show that the PES phase was significantly different $(p<0.001)$ from the EMS and $\mathrm{PH}$ phases, whereas the EMS and $\mathrm{PH}$ were not significantly different to one another.
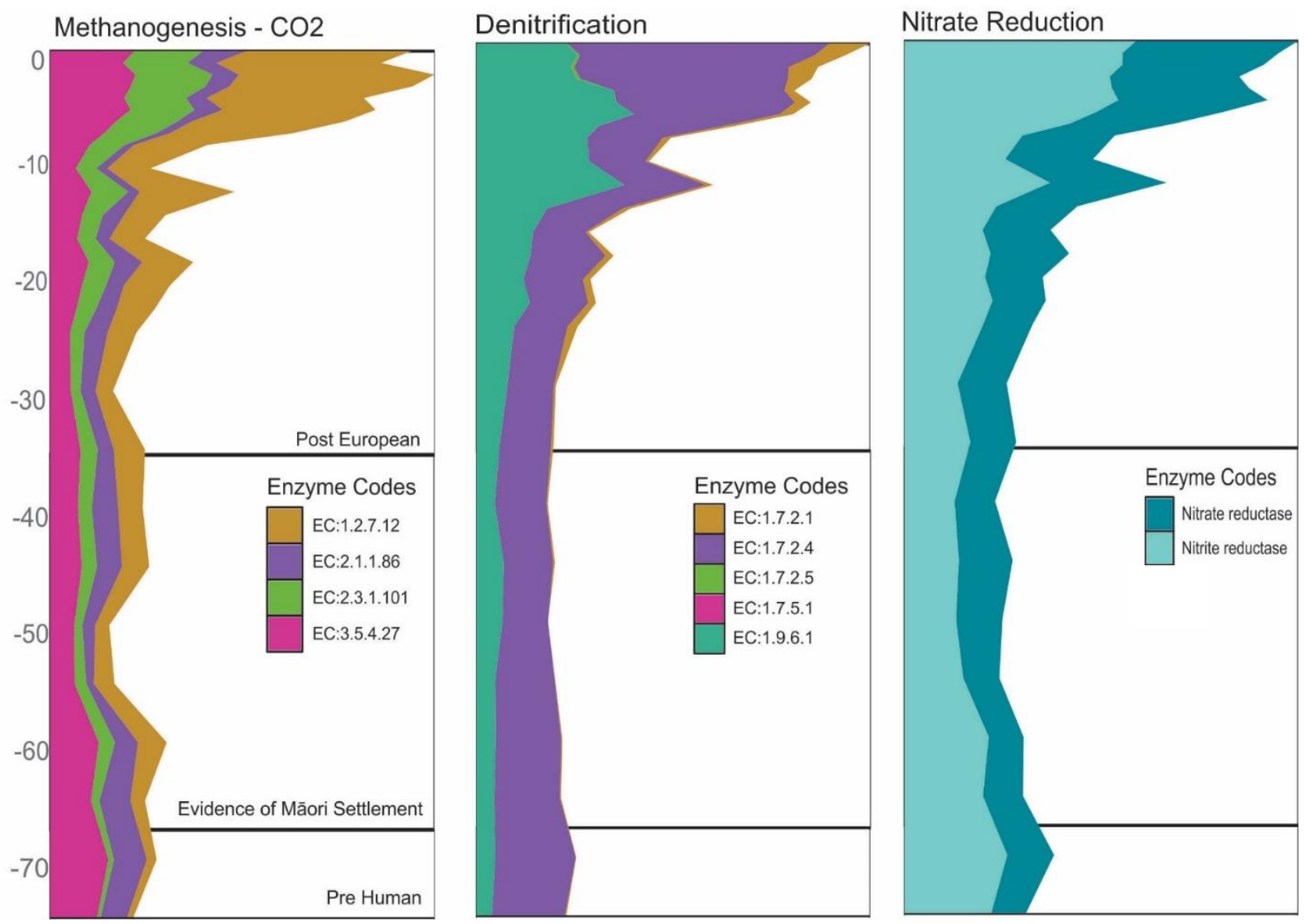

Figure 12. Time-series plots of three enzyme relative abundances (log-transformed) involved in key metabolic pathways - determined using the metabolic inference pipeline PAPRICA, then compared to the MetaCyc database to match sequences to a closest consensus genome and assign enzyme codes (EC numbers, https://www.brenda-enzymes.org/index.php). 
Three key metabolic pathways show marked shifts across the study period (Fig 12). These were four $\mathrm{CO}_{2}$ methanogenesis enzymes, two denitrification enzymes and two nitrate reduction enzymes. All of these enzymes remained relatively stable across the $\mathrm{PH}$ and EMS phases before increasing markedly in the top $15 \mathrm{~cm}$ of the sediment core.

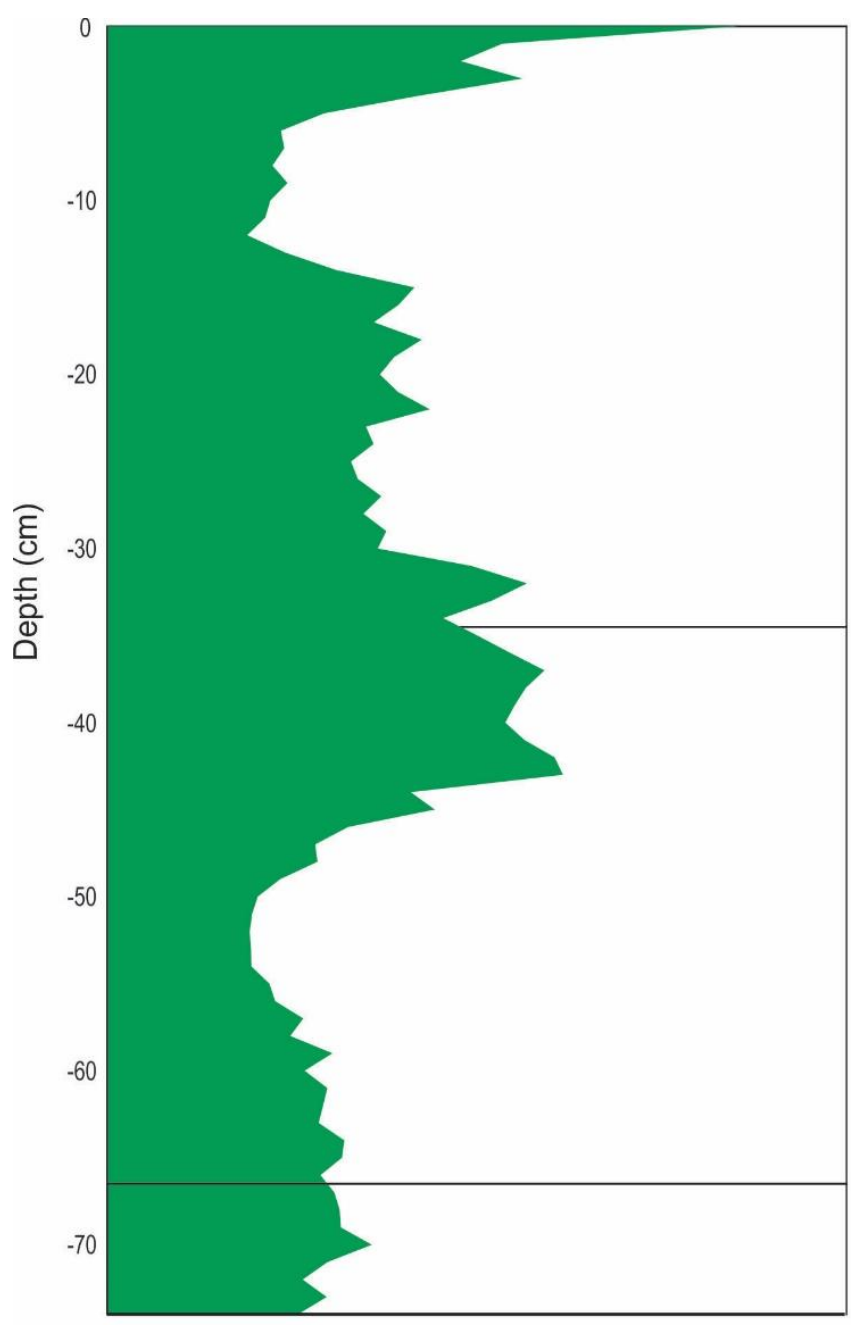

Index

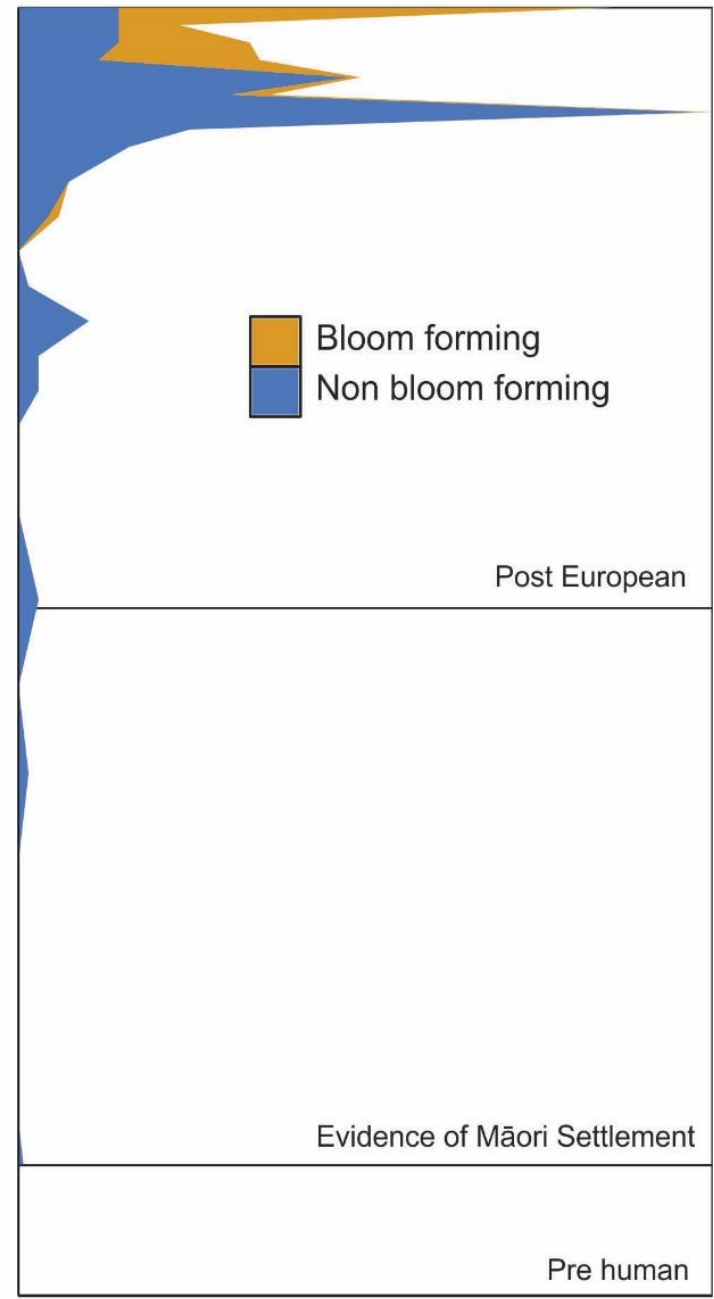

No. of reads

Figure 13. Hyperspectral plot (left), same data as for Fig.9, and the Cyanobacteria sequences extracted from the $16 \mathrm{~S}$ rRNA metabarcoding data (right). Bloom forming cyanobacteria selected were Microcystis, Aphanizomenon and unclassified Nostocales.

Analysis of the cyanobacteria component of the metabarcoding data showed that they have been present in the lake for many centuries, with low levels detected during the EMS phase (Fig. 13). During the EMS phase all cyanobacteria were from the Order Synechococcales which are picocyanobacteria. These become more abundant in the latter third of the PES phase. This 
also corresponded with an increase in bloom forming and potentially toxic genera including Microcystis, Aphanizomenon and unclassified Nostocales. The increase in bloom forming cyanobacteria aligned with an increase in the hyperspectral index (Figure 13). There was no notable increase in cyanobacteria prior to this, suggesting that the increase in hyperspectral signal (between $15-45 \mathrm{~cm}$ ), was not due to cyanobacteria.

\subsection{DISCUSSION:}

\subsubsection{PALYNOLOGY}

The palynology results for Lake Moāwhitu suggest a change in forest structure and composition that align broadly with pollen and charcoal records reported from across Aotearoa (McGlone et al, 1989; and further references cited in 3.5.1). As indicated in 3.5.1, the Moāwhitu pollen zonation's reflects both overall vegetation history since pre-human times and impacts on the local vegetation arising from human settlement. These details are further elaborated here.

\subsubsection{VEGETATION RECONSTRUCTION}

The first part of the pollen record (from the base up to $68 \mathrm{~cm}$ ) indicates that the regional vegetation was dominated by beech forest with tall podocarps (in particular matai, tōtara, rimu) present at lower altitudes and probably close to the lake itself. This is consistent with descriptions of native vegetation descriptions in the region today (Wardle, 1991). The predominance of beech forest is indicated by high levels of Fuscospora pollen, which is a generic taxon that includes four species whose pollen grains are indistinguishable from one another (Moar, 1993). These four species are Red beech (Tawhai raunui), Black beech (Tawhai rauriki), Mountain beech (Tawhai rauriki), and Hard beech (Tawhai raunui). Of these we can probably exclude Mountain beech as contributing to the Moāwhitu pollen grain but Wardle (1991) reports that the other three species are common in the area today. Of these, Hard beech occurs widely below $650 \mathrm{~m}$. and locally dominates narrow spurs, often descending along these almost to sea-level.

The consistent presence of beech throughout the pollen record is likely due to the regional distribution of beech forest, presumably at higher elevations, and the taxon's propensity for 
high volume pollen production and long-distance pollen dispersal. This is typically why beech pollen is typically over-represented in New Zealand pollen records including northern South Island (Jara et al., 2015). These observations are consistent with local presence of the tall podocarps within the catchment, occurring close to Lake Moāwhitu, and the more distant occurrence of beech forest in inland and upland parts of the region, as is observed today (Wardle, 1991). This interpretation is supported by the next shift we see in the core record from 68 - $55 \mathrm{~cm}$ where both tōtara (Podacarpus spp.), and matai (Prumnopitys feruginea) decline abruptly to much lower levels in the core record. The distinct decline in native podacarp taxa, as beech maintains a consistently strong presence, is consistent with pollen and charcoal records across Aotearoa (McGlone et al., 1989; Wilmshurst et al., 2008, 2011; McWethy et al., 2009).

\subsubsection{THE FIRST VISIBLE EVIDENCE OF HUMAN CONTACT}

Until their decline commencing $\sim 68 \mathrm{~cm}$, podocarp trees were a major component of the vegetation around the lake and within the lake catchment. Their decline probably reflects deliberate clearance by the earliest discernible settlers to enable better access to those direct resources that the lake provided (e.g., fresh running water and mahinga kai) and to provide intrinsic material for constructing shelter, waka, etc. Consequently, it was this local vegetation that went into decline first and never recovered, whilst the regional beech forests remained largely intact. More generally, podocarp forest clearance also made way for agricultural use and the planting of crops (in particular, kumara) for an all-year-round food supply. This is consistent at similar sites in Aotearoa where utilization through clearance of the resource (i.e. clearing the local forest) in turn provided access to other life sustaining resources (Newnham et al., 2018).

\subsubsection{THE PRE-EUROPEAN MĀORI ERA}

At Moāwhitu, the clearance of local forest appears to link to a staple food resource that was extensively used by Māori. At $75 \mathrm{~cm}$ bracken fern (Pteridium esculentum) appears in the sediment record. This coincides with an increase in charcoal (fig 8) signaling the clearing of forest (tall trees) enabling the bracken fern to thrive (McGlone et al., 1989). This combination 
is also seen in pollen records from across New Zealand indicating deforestation by fire that accompanied the 'first wave of extensive settlement' of New Zealand by Polynesian/Māori peoples (McGlone et al., 1989; Wilmshurst et al., 2008, 2011; McWethy, 2009).

Native grasses, grouped under the family Poaceae, follow a similar pattern to bracken fern increasing with deforestation. Sedges also emerge at this time, however given their wide range and accompanying difficulty to distinguish between the pollen of different sedge species, all sedges are grouped under Cyperaceae. One such type of sedge vegetation is pikao (or pīngao), also known as the Golden Sand Sedge (Desmoschoenus spiralis). Pìngao is a stout, grass-like plant, $30-90 \mathrm{~cm}$ tall and is found on active sand dunes, similar to those in the vicinity of Moāwhitu. The major increase of sedges at the time of deforestation however is more likely to represent the expansion of wetland communities at the time. In support of this observation, the pollen of another important wetland plant, Typha (raupō), also appears in the record at the onset of deforestation and remains important throughout the EMS phase.

There are several possible reasons for this wetland expansion. If, as has been argued earlier, tall podocarp forest occupied the surrounding margins of most of the lake, the lightdemanding wetland species would have been suppressed. Conversely, the clearance of those fringing trees would have favoured the development of wetland communities both through light exposure and through higher nutrient flux due to the mobilization of soils, which typically accompanies tree removal (McGlone et al., 1989). Another possibility is that early Maori settlers actively promoted the expansion of these wetland communities to provide additional resources, in particular, for weaving and for mahinga kai. Kaumātua specifically referred to raupō (Typha) for fish habitat and harakeke/Wharariki (Phormium) for clothing (piupiu) in the mātauranga chapter (see chapter 4, section 4)

Another wetland plant of interest, harakeke (Phormium), shows little presence on the diagram, compared to raupō. Phormium is typically under-represented in New Zealand pollen diagrams as the pollen grain is notably heavier, relying on birds and other organisms to disperse its seeds locally compared to raupō whose pollen is lighter and carried further by wind. Nevertheless, the few grains of harakeke pollen recorded show a pattern consistent 
with the better-represented wetland taxa (sedges and raupō) with stronger presence in the human settlement phases.

\subsubsection{THE EUROPEAN ERA}

With evidence of land clearance occurring during the Māori/Polynesian era, bracken and the native grasses colonize and continue to thrive, along with wetland communities. From 40 $\mathrm{cm}$ up-core the largest spike in charcoal (80\%) is combined with the emergence of the exotics i.e. Pinus (pine) and to a much lesser extent Taraxacum (dandelion) and Rumex (dock). This change in vegetation is consistent across Aotearoa at this time with European settlement in the early nineteenth century, namely further deforestation, and the appearance of these exotic plants. There is a notable surge in Poaceae (grasses) at this time, which suggests or reflects large scale pastoral land use (Ogden et al. 2006). The decline of bracken fern also suggests both the scale of early European farming and possible change in lifestyle and diet for Māori in this era and could point to a shift both geographically and demographically of Ngāti Koata from their traditional mahinga kai site at Lake Moāwhitu as well as their customary practices.

\subsubsection{IN-LAKE PRODUCTIVITY OVER TIME}

The results from the hyperspectral scanning (Figure 9) are presented in the context of this human settlement framework, allowing some insights into the relationship between water quality and land use change. In-lake productivity is very stable during the pre -human phase extending into the early Māori period. This is comparable and consistent with the palynological findings in that relatively stable vegetation communities also prevailed within the lake catchment at least during the pre-human period. As shown in Figure 13, this early period of low in-lake productivity corresponds with the virtual absence of cyanobacteria, therefore reducing the potential for algal blooms.

The in-lake productivity signal begins to climb from $50 \mathrm{~cm}$ up-core which raises the question why? From the pollen record we can deduce that the initial land clearance may by then be resulting in higher nutrient flux into the lake, promoting productivity. This trend is persistent, leading into the European phase although the signal decreases at $30 \mathrm{~cm}$ before dropping significantly at approximately $15 \mathrm{~cm}$. The latter decline in productivity could align with the 
draining of the lake (in 1948; Patete, 1997) although the mechanism for this is not entirely clear. The hyperspectral analysis used in this study measures the pigment chlorophyll-a, or degradation products. The higher values measured in the lake during the EMS phase could be due to a higher abundance of macrophytes (aquatic plants) and fringing wetland plants, as indicated in the pollen record. Later, with the draining of the lake, that the habitat is suitable for macrophytes likely reduces as well, and may account for the observed decrease in the hyperspectral signal. Further analysis of samples from the sediment core using pigment analysis (to identified pigments species to different algal groups) or macrofossil analysis would be required to explore this explanation.

The 1900s saw the conversion of land around Lake Moāwhitu to pastoral use. Draining the water from Moāwhitu was an efficient cost-effective way to convert lake to land for farming. The implications for this may be reflected in the major changes in water quality indicators observed towards the top of the core. In particular, increases in in-lake productivity align with increasing prevalence of bloom forming cyanobacteria which is indicative of poor water quality (Fig 13). Pastoral land use is one of several anthropogenic impacts linked to poor water quality which in turn has a negative bearing on the health and abundance of tuna populations.

\subsubsection{BACTERIAL COMMUNITY COMPOSITION (MICROBIAL)}

Microbes are involved in almost all biogeochemical processes in lakes and are at the base of food-webs (Allison et al, 2008). Despite their importance, until recently it has been challenging to study their composition. The advent of new molecular technologies, such as metabarcoding - used in this study - now allows in-depth analysis of their diversity.

The microbial community composition remained relatively constant throughout the $\mathrm{PH}$ and the EMS phase. One of the limitations with the analysis undertaken in this study was that there were only two samples analysed from the PH phase. This reduced my ability to determine what the natural baseline community was. More samples ( $\sim 5$ to 10 samples from this period need to be analysed for stronger conclusions to be drawn. Nevertheless, the stable microbial community indicated for this period aligns with the hyperspectral scanning and palynological findings suggesting a relatively stable lake ecosystem. During this period the nearby closed canopy forest would have decreased light at the edges of the lake and decreased nutrient and sediment runoff into the lake. 
At about $54 \mathrm{~cm}$, there is a marked shift in the microbial community (Fig 10), which aligns with a rise in the signal in in-lake productivity, but follows after the initial forest clearance at Lake Moāwhitu. Burnings and clearing of vegetation result in increased soil erosion within a catchment and consequently cause more nutrient-rich sediment to enter lakes (McGlone \& Wilmshurst, 1999; McGlone, 1989). Although the structure of the microbial community shifts, there is not a corresponding change in their inferred function, which may indicate functional redundancy. Functional redundancy is an ecological phenomenon, whereby multiple species from a variety of taxonomic groups can share similar roles in ecosystem functionality, for example, nitrogen fixation, nitrate reduction etc. Given that there is no obvious shift in function of the bacterial community this also adds further evidence to the suggestion above that the changes in the hyperspectral signal at this depth may be due to an increase in macrophytes and wetland communities.

There is a decrease in the hyperspectral signal at about $12 \mathrm{~cm}$, which was noted above as perhaps due to decrease in depth of the lake. This may have also resulted in a small-scale shift in the microbial communities as samples $12-8 \mathrm{~cm}$ are notably different in the NMDS plot (Fig 11). There is also a shift in the inferred function in the $12 \mathrm{~cm}$ sample (Fig 11). However, the most marked shifts in the community composition occur from about $7 \mathrm{~cm}$ upwards. In particular, Gammaproteobacteria from the families of Rhodocyclaceae and Arenicellaceae increase. The most abundant AVS in the surface samples are Dechloromonas (family Rhodocyclaceae). These are often among the dominant denitrifying populations in activated sludge tanks of wastewater treatment plants and are indicative of sediment that is now nutrient enriched (Chen et al. 2019).

The inferred function analysis showed a marked increase in $\mathrm{CO}_{2}$ methanogenesis, denitrification and nitrate reduction over these depths (Fig 12). Methanogenesis is the formation of methane by microbes. It occurs in anoxic environments and is the final step in the decomposition of biomass (Nozhevnikova et al. 1997). Denitrification is the microbial process of reducing nitrate and nitrite to gaseous forms of nitrogen. Denitrification is considered a response to changes in the oxygen concentration in the surrounding environment. Nitrate reduction is also generally considered an anaerobic process in which an 
organism derives its oxygen from nitrate (Lam et al. 2011). An increase in all of these enzymes likely suggests sediment anoxia is increasing in the lake sediment. This is likely a response to increased microbial respiration as they decompose organic material, suggesting the lake is becoming increasingly eutrophic over this time period. One of the most striking findings of this thesis is that this eutrophication trend commences early in the European era and increases progressively towards the present.

Cyanobacteria are a group of ancient oxygenic photosynthetic prokaryotic organisms (Whitton and Potts, 2000). At least 50 species are known to have strains which produce toxic natural compounds (cyanotoxins). Cyanotoxins are a threat to humans when ingested (via water supplies or accidental swallowing) or from contact (dermal or inhalation). When the cyanobacteria portion of the metabarcoding data was extracted and plotted there was a clear increase in the PES phase. Initially this was picocyanobacteria, but in the most recent sediment there has been a shift to bloom forming species. Of most concern is the presence of Microcystis, which is a notorious bloom forming species which produces the hepatotoxin microcystin (Harke, 2016). This toxin has been shown to accumulate in tuna, creating a potential health risk if they are consumed, and the toxin can also impact their health and breeding potential (Acou et al. 2008). Metabarcoding is only considered a semi-quantitative, technique and therefore I suggest that the observation on increasing cyanobacterial abundance is further explored using a cyanobacteria specific ddPCR and/or testing for toxins in the sediment core (Henao et al. 2020). Nevertheless, the stratigraphic pattern of cyanobacteria parallels that of the eutrophication indicators in showing progressive increases during the European period.

\subsection{CONCLUSION}

The key finding of this part of the work is that lake water quality, indicated by bacterial indicators of eutrophication and algal blooms, has deteriorated markedly throughout the European era and increasingly towards the present. To the best of my knowledge, and based on recent surveys, no non-native fish have been introduced to Lake Moāwhitu. This is 
relatively rare, as fish have been introduced to most New Zealand lakes. These introductions have triggered changes in food webs and nutrient concentrations elsewhere (Ho et al, 2011). In the absence of exotic fish introductions, therefore, the changes that have occurred in the health of Lake Moāwhitu are therefore most likely due to increased nutrients and sediment runoff into the lake, accompanying the development of pastoral farming in the lake catchment.

The palynology data indicates a succession of native vegetation clearance and land-use change that presumably began shortly after Māori settled in the region. The native forest removal would have resulted in an increase in nutrients and sediment entering the lake and yet the water quality indicators do not immediately show significant deterioration until later in this period. These clearances also altered the environment at the lake margins, promoting the development of wetland communities dominated by sedges and raupo. There are corresponding changes in lake productivity, although the processes and sources of productivity change remain unclear. In this study I have focused only on bacteria and algal communities which do not allow me to investigate food-web changes. Nevertheless, from the data presented, it is reasonable to hypothesise that the wetland communities promoted by forest clearance during the EMS period were able to intercept much of the presumed nutrient flux that otherwise would have entered the lake and promoted eutrophication and algal blooms. Once pastoral farming took hold in the European era, intensifying in recent decades, these wetland communities declined and this in combination with further deforestation in the catchment and increased nutrient flux led to the water quality deterioration observed at the lake today.

Although I was unable to get the tuna specific ddPCR assay working on the down core samples within the time frame of my Masters, the interviews undertaken as part of chapter 4, indicate that tuna populations in Lake Moāwhitu have declined. The reasons for decline are not clear. Interestingly, researchers have found that long-fin tuna are larger and grow faster in pasture settings compared to native tussock (Broad et al., 2002). The rationale for this is that pasture sites are likely to be associated with higher nutrient levels, increased light, and therefore increased growth. It is also thought that lower water temperatures associated with forested areas compared to open pasture may partially explain lower eel growth (Broad et al., 2002). Therefore, the decline in water quality in Lake Moāwhitu is probably not the main reason for 
tuna population decline. Removal of forest around the lake likely reduced in-lake structures (i.e. woody debris entering the lake) which may have served as important habitat for tuna. The wetland adjacent to Lake Moāwhitu have also been extensively modified and drained in recent decades, which would have hindered migration. There is a high potential for the most recent changes in water quality in the lake to impact tuna over the forthcoming decade and this process may well have already begun. For example, the toxins produced by cyanobacteria have been shown to have detrimental effects on tuna health and reproduction (Acou et al. 2008).

These keys findings have provided a sound framework to establish historical reference states linked to associated cause and impact on the Lake Moāwhitu ecosystem. We now turn our focus to the Indigenous stream of Māori knowledge, mātauranga Māori, in the pursuit of complementary, contrasting, and qualitative data. The potential generation of new knowledge and findings through open collaboration will enable the creation of solutions to address the enhancement of tuna health and population. 


\section{ChAPTER 4 - MĀTAURANGA MĀORI}

Drawing on the journey, survival and emancipation of mātauranga Māori to revitalise tuna populations.

\subsection{MŌTEATEA}

Whakarongo ki te au o ò tātou tuakana - ka tangi rātou me he reo nō te puehu

E ngā uri o Tū, kua aha koutou? tō whakamā hoki!

Nā mātou ō tuākana te oranga i toitū ai, nā mātou anō koutou i whāngaitia ki tāu i hiahia ai, i tō ake haerenga hoki i te ao tūroa nei ...

Kua tae te wā kia karangahia koutou e mātou, kei mate ā-moa...

ka tō te rā, e pātata ana te wā, tē awhi, tē tiaki o koutou puna wai e mātou...

ka kawea atu mātou e te au o te kaiapotanga, o te kaiponutanga o te tokoiti.

Nā wai ka hoki ki tō mātou tūpuna a Tangaroa, ki a Papatūānuku, ki te one ō raro, ki te puehu.

E kore rawa e rongona anōtia ō mātou reo, haere rā...

Listen to our tuākana - they cry out as a voice from the dust.

"Oh humanity, what have you done, where is your shame! We your tuākana have sustained life, have sustained you in your time of need, in your journey of life... Now it is for us to call to you before we are no more... the sun sets, soon we no longer grace and guard your waterways... We depart on the current of all consuming greed, the mindless actions of the few. And so we return to our tūpuna in Tangaroa (ocean), to Papatūānuku, the soil below...the puehu (dust), silenced forever more, farewell. 


\subsection{INTRODUCTION}

As was mentioned in the introduction of this thesis (page 10), this chapter now turns to the approach of addressing the mātauranga Māori context and format to this thesis.

This thesis leverages two knowledge baskets, western science and mātauranga Māori, to compare and embrace both methodologies in the pursuit of restorative aspirations for tuna populations. The title of the chapter connects to whakapapa and mātauranga Māori to illuminate the current plight of this treasured, enigmatic, and endangered animal whilst embedding a kaupapa Māori approach to research. As expressed in the mōteatea above, "A voice from the dust", refers to the whakapapa of tuna, or the symbolic (and literal) presence of their tūpuna in the sediment who "cry out" to humanity for survival and sustainability of their posterity. I was inspired to write this mōteatea because for me it represents their futile voice and in it we hear their anguish and disappointment in their teina (younger human siblings). We hear their plea reminding teina (humanity) of their duty as kaitiaki, and as such humanity are mandated by tuna to protect and sustain life.

A western scientific approach also connects to the 'dust' or, in this case, the sediment layers beneath lake-bed repositories and the evidence of past life and environments that they preserve. The nation-wide project that is Lakes380 grew from a near complete lack of (western) historical record of Aotearoa lakes. Within the context of freshwater degradation in these lakes, an urgent need was identified to conduct research using Environmental DNA (eDNA) to detect the presence of tuna DNA in lake-bed sediment that spans the past 1000 years or so. Having engaged with the first knowledge basket and in light of those findings, this thesis now turns to the second basket which addresses a western science knowledge gap by providing historical evidence of tuna at Lake Moāwhitu from manawhenua.

This chapter looks at the relationship of Māori with tuna through whakapapa within the body of mātauranga Māori. It begins by consulting relevant literature that concerns the epistemology of mātauranga Māori, and ways in which this body of knowledge combines with western science as well as potential tensions that emerge between the two knowledge systems. Tensions are explored to highlight how they might be managed or where they provide opportunity for improved understanding across these two fonts of knowledge. 
The Methodology section begins by providing some relevant historical context to this study of Lake Moawhitu that tells of the coming together of Ngāti Koata and tuna at Rangitoto ki te Tonga, further illustrating what ties both tuna and Koata to this lake. A kaupapa Māori methodology is then outlined, that includes wānanga, kānohi kitea, haerenga (fieldtrips), and draws from historical sources and site visits to Lake Moawhitu with manawhenua and kaumātua alike. Based on this form of methodology, specific findings are drawn to provide insight into the connection between manawhenua (Ngāti Koata), whenua (Rangitoto ki te Tonga), te roto (the lake) and tuna.

\subsection{MĀTAURANGA MĀORI}

Mātauranga Māori represents the tradition or continuum of Māori knowledge weaving forward and backwards through whakapapa (Harmsworth, \& Awatere, 2013). Timoti Karetu's humbling concept of Te Here Tangata (The Rope of Mankind) sees his hands on a rope stretching into the past for the fifty or so generations he can see, further to the instant of Creation, and on into the future for at least as long (Karetu, 1975). Mercier (2018) explains that mātauranga Māori encompasses traditional and contemporary knowledge and is becoming increasingly sought after and integrated into mainstream education, research and environmental policy in Aotearoa New Zealand. Mātauranga Māori is often translated simplistically as 'Māori knowledge' (Mead, 2003). Yet, it goes well beyond this: "...it is a tool for thinking, considering the ethics of knowledge, and informing us on 'te ao' (our world) and our place in it" (Mead, 2003, p. 306). Hikuroa (2016) agrees, stating that "...this knowledge is generated using techniques consistent with the scientific methodology based on evidence, incorporating culture and values, and explained according to a Māori world view."

Historical observations of tuna (long and short finned eel) from early Māori enabled their categorization according to species, size, colour, taste, role (migratory/non-migratory), and personality trait e.g., aggressive/passive (Department of Conservation and Te Wananga o Raukawa, 2014). Tuna kūwharuwharu (long finned eel, endemic to Aotearoa) adorned wharenui (meeting houses) on whakairo (carvings) alongside tūpuna (iwi ancestors) and attests to their cultural value by Māori as a tāonga (treasure), kaitiaki (guardian) and tuākana (elder sibling) (Potangaroa, 2010). 
A worldview (Te Ao Māori) perspective links mātauranga tuna to their relationship (as tuākana) with Māori considering everything that is living and non-living to be interconnected (Harmsworth, \& Awatere, 2013). Whakapapa (genealogy) describes these connections and tells the story of how people, the landscape, plants, and animals came into being. Taonui (2011, citing Mitira, 1972) explains that whakapapa maps relationships so that mythology, legend, history, knowledge, tikanga (custom), philosophies and spiritualties are organised, preserved, and transmitted from one generation to the next. This information that is transmitted is known as mātauranga Māori. The relationship between tuna and Maori has been preserved through time and affirms the tuākana (older sibling) - teina (younger sibling) connection from the origins of creation underlining the hierarchical status of tuna over human-kind (Fig 4.1).

\section{A Whakapapa for Tuna is:}

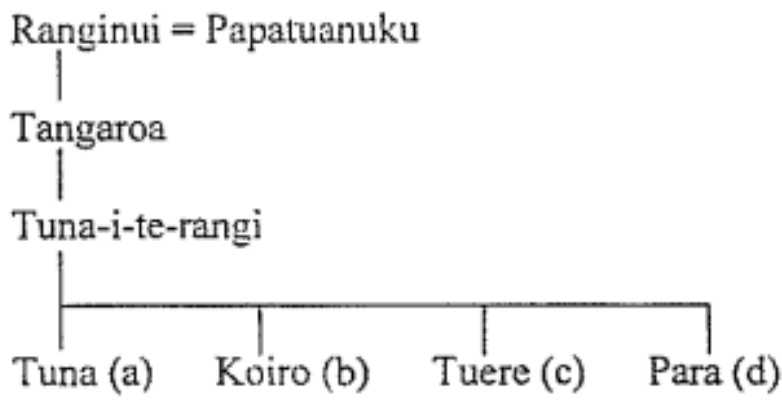

(a)

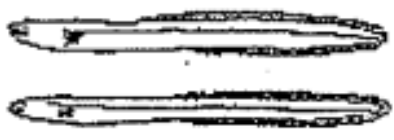

(b)

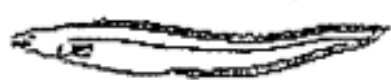

(c)

(d)

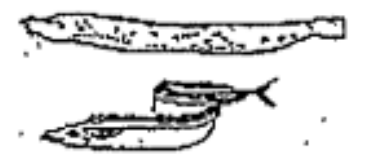

Figure 14 Whakapapa of tuna (Te Tau Ihu Mahi Tuna: Eel Management Plan, 2000)

Maori deities feature prominently in the above illustration of whakapapa from our Sky Father (Ranginui) and our Earth Mother (Papatūānuku). This clearly visualizes where tuna sits, holding chronological status above other organisms, including Māori and humankind.

Providing a simplistic definition, "papa" is anything broad, flat and hard such as a board. "Whakapapa" is to place in layers, lay one upon another. Hence the term whakapapa is used to recite in order the genealogies, layer upon layer, from the past to present, to future (Karētu, 1975). Whakapapa is at the core of traditional mātauranga Māori (Taonui, 2011).

Mātauranga Māori links to whakapapa are based on traditional origins with reliance on the senses (through observations and perceptions), and connectivity to te taiao (the 
environment). Whakapapa creates connection to valued places and resources through such methods as oral lineage, whakataukī (proverbs), mōteatea (laments), waiata (songs), pepeha (tribal identity), pūrākau (stories and narratives) and mātauranga (knowledge) These combined validate connection to the resource, use of the resource (mahinga kai), and a 'sense' of wellbeing (Awatere et al, 2017).

These senses are not exclusive to the natural world, but extend to the wairua, by having a spiritual attachment to the resource (Awatere et al., 2017). It is these oral recitals that act as vehicles for the transmission of knowledge from one generation to the next (Whaanga et al., 2018). Tuna, according to Potangaroa (2010), is also one such vehicle for knowledge transmission (see 4.1.1 section below) (Department of Conservation and Te Wananga o Raukawa, 2014). Therefore, mātauranga Māori is said to be timeless, having:

..no beginning and is without end. It is constantly being enhanced and refined. Each passing generation of Māori make their own contribution to mātauranga Māori. The theory, or collection of theories, with associated values and practices, has accumulated mai iTe AoMāori / from Māori beginnings and will continue to accumulate providing the whakapapa of mātauranga Māori is unbroken (Winiata, 2001, cited in Mead 2003, p. 321).

A way to visualize the connections between whakapapa and matauranga is shown in Figure 15.

\begin{tabular}{|lll}
\hline Whakapapa $\longrightarrow$ & Histories \\
Narratives \\
Experience's
\end{tabular} $\begin{aligned} & \text { Māori-centered } \\
& \text { research } \\
& \text { frameworks }\end{aligned} \quad \begin{aligned} & \text { Thinking } \\
& \text { Debating } \\
& \text { Creating }\end{aligned} \longrightarrow$ Storing $\longrightarrow$ Mātauranga Māori.

Figure 15: Generation of Māori knowledge. Modified from Graham (2009)

With this in mind, mātauranga Māori encompasses traditional and contemporary knowledge and is becoming increasingly sought after and integrated into mainstream education, research, and environmental policy in Aotearoa New Zealand (Mercier, 2018). 


\subsubsection{Mātauranga MĀori and Western SCIEnCE - The tWo 'KNOWLedge baskets'}

According to Hikuroa (2017, p. 5-10), “...science is knowledge that is generated based on methodology" and grounded on evidence (British Science Council, 2009). Hikuroa reasons that the senses are the primary source of empirical evidence based on the key tenets of scientific methodology, hypotheses and prediction, where knowledge is acquired by observation and experimentation. If validity is in doubt, it is either due to a lack of evidence or a failure to repeat results (Mason, 2004). Hikuroa (2017) refers to observation and trial and error which are scientific methods applied to all aspects of Kumara cultivation including growing, storage and use of this traditional source of kai (food). The motivation for ancient Māori to grow food and sustain life was critical and left little room for error. Observation, experimentation and replication was as crucial to their civilization as it is in our day and age. The knowledge held and developed through successive generations fortified ancient Māori in the arts and discipline of 'science' many centuries ago.

The need for western science and mātauranga Māori knowledge to synthesise for ecosystem sustainability has never been greater. Mercier (2018) suggests this convergence of distinct knowledge streams is experiencing varying degrees of success depending upon the extent of exchange and engagement. Underlying the success of interaction is understanding "how to work at the interface of science and Indigenous knowledge" by seizing the opportunity to learn about "the other, and to learn about the self" (Mercier, 2018, p.84). This implies that a genuine willingness to acknowledge, learn, and integrate mātauranga Māori will, in turn, teach western science about itself, and vice versa. This suggests that the key to the convergence of two distinct knowledge streams is based on acceptance, respect, and a shared resolve to tackle and restore balance within our ecosystems.

Acknowledging that mātauranga Māori includes aspects of a scientific nature, and, that science systems espouse a social, values-based approach is according to Medin and Bang (2014), a step in the right direction. This seemingly simple case of 'mutual respect' (Durie, 2005), may also be key to capturing new knowledge at the interface where two streams converge (Durie, 2004). As the next section shows, however, there remain deep rooted tensions that link to historical research methodologies applied to Indigenous cultures manifested through power imbalances, knowledge inequalities, and cultural marginalization (Smith, 2016; Tauwhare, 2008). 


\subsubsection{TENSIONS BETWEEN KNOWLEDGE SYSTEMS}

One of the key tensions related to mātauranga Māori is its relationship with western science. Smith (2016) explains that tensions can arise simply as issues with "research terminology and translation, escalating to more complex differences in the ideas, philosophy, and sociology of knowledge." Mercier (2018) explains that the term western science has been and is used to differentiate itself from the 'non-West' for practical reasons, and includes the ancient philosophical, enlightenment, and scientific revolutionary sciences. Interestingly, in the same light western science is accused of "being ethnocentric, ignoring science's plurality of cultural contributions" (Medin and Bang, 2014, cited by Mercier, 2018).

Tauwhare (2008) suggests from a mātauranga Māori viewpoint that Māori preferences to refer to 'western science', rather than 'modern science', enables continued discussion on what is and what isn't science, given the linkages of western science to imperialism, conquest, and the assimilation and/or suppression of other cultural traditions (Tauwhare, 2008; Morgan and Manuel, 2020). Similarly, the use of 'modern' (as in modern science) "speaks to postcolonial motives of modern science and may imply future knowledge may remain rooted in and controlled by and through a western science tradition [...] ensuring Mātauranga Māori remains on the margins of future knowledge" (Tauwhare, 2008, p. 4). These issues speak to western science links to hegemonic knowledge systems, and its ties with colonial projects (Durie, 2004).

According to some commentators, the lack of hypotheses in Indigenous knowledge is what differentiates it from its modern science counterpart (Crawford, 2009, cited by Mercier, 2018). In contrast, Walker (1994) contends it was mātauranga that led the first people to arrive in Aotearoa, suggesting observations of bird migratory patterns led to the hypothesis of land in the direction of the yet-to-be discovered Aotearoa, New Zealand. It may be argued that the hypothesis was tested with a robust experiment and, ultimately, accepted.

By contrasting these styles, we see objectivity and reductionism employed by western science compared to a mātauranga Māori inductive reasoning approach, including abstract theorizing or speculation (Hikuroa, 2017). A reductionist worldview reduces complex systems into smaller parts in order to make sense of the complexity of the whole (Cheung, 2008). These 
fundamental differences originate from their respective and distinct approach or 'method' by which they view, analyse, and interpret phenomena. Smith (1999) maintains a western science methodological approach to research has inherent risk as it isolates the subject of study. For example, by studying the Māori village in isolation, a western science approach creates a disconnect from the village to the multi-faceted lifestyle of Māori such as whakapapa, whanaungatanga, kaitiakitanga, wairuatanga and other principles that cannot be captured, analysed, and interpreted as distinct or separate components. Further explains Smith (1999), this type of research provided little in terms of extending the knowledge of Māori people. Rather, Smith contends, this type of research generated ideologically laden data about Māori society, distorting ideas of what it means to be Māori. By highlighting these distinctions between worldviews and the inherent tensions generated, the task of how best to navigate between and within the two knowledge streams and methodologies remains challenging.

Hikuroa (2017) reasons that both knowledge streams are methodically created and contextualized within a world view. Cheung (2008) contends that the challenge is holding both worldviews side-by-side, encouraging and creating open-mindedness to alternative approaches, and ultimately potential for Māori to make unique contributions to science. The following table (Table 4.1) compares what Hikuroa believes to be the major methodological differences between the two knowledge streams.

Table 1. Some differences between Mātauranga Māori and science (Hikuroa, 2017)

Mātauranga Māori $\quad$ Science

Participatory 'experiencers' of systems Detached 'observers' of systems

Explicit intrinsic values

Implicit instrumental values

Knowledge as belonging

Knowledge for control

Intuition as method

Intuition rarely acknowledged

Inclusion of facts and values

Facts and values separated

Everything is interconnected

Everything physical is interconnected 
These methodological differences (Table 4.1) highlight the differences between the two world views, from a consideration of an interconnectedness of everything living and non-living, to a reductive study of the independent parts. The objective approach was adopted by early colonial explorers who employed and documented fragmentary, detached observations of early Māori. This form of research methodology only served to marginalize early Māori and embedded a deep mistrust and cause of suspicion towards a western science approach (Hikuroa, 2017, p.39).

Further tension arises when Indigenous Māori researchers face disparities about how their research is counted and valued in relation to what kind of research is valued by funding bodies. Increasingly, Indigenous academics are required to account for themselves as 'researchers' in ways that take a limited view of what counts as legitimate research. What is counted may not reflect the legitimacy of mātauranga, and the significance of their research to communities. Smith $(2016$, p2) argues that Indigenous knowledge is "expected to fit normative academic definitions and criteria." Citing Kovach (2009), Smith highlights a lack of recognition of Indigenous methodologies as a distinct form of inquiry, which results in a form of discrimination (Ryan, 2000). The wider implications are manifest in the imbalance of funding available to kaupapa Māori research projects (Smith et al, 2016) and are further magnified in reports or theses such as this one, that require explanation or a rationale as to what, how and why we do, within a very particular framing. For example, this thesis ends (Chapter 5, p. 97) by drawing upon ancient scriptures that through a western science lens might be deemed unsuitable or not relevant, but which resonate loudly with Koata people, through their whakapapa. According to Smith et al (2016) these inequalities that include access to external funding, publishing in a colonizing language, and the lack of international journals that value Indigenous scholarship marginalize this scientific knowledge stream.

That western science traditionally tends to reduce and compartmentalize Indigenous knowledge (IK) in order to make it fit, challenges the ways in which both knowledge streams can play to each other's strengths (worldviews), with mutual purpose and benefits in mind. Smith contends this methodological approach to working with IK mātauranga all but creates a disconnect for Māori on the basis of a non-Indigenous, non-integrative research approach 
conducted through a western science lens. In so doing there is potential to alienate its (IK mātauranga) own identity and uniqueness "...from its Indigenous communities and context, where it all began, and where it still informs identities, ways of living and being" (Smith et al., 2016; Abstract). Over the past 30 years this disconnect has been seriously challenged by Māori academics working to bring Māori researchers to the fore, to examine, deconstruct, and promote mātauranga Māori as a distinct, integrative, and expanding contributor to real world, contemporary solutions. This is why Smith et al. insist on the need for Māori academics/researchers to take out 'the noise' or tensions by taking time to carve out their own space for the examining, deconstructing and application of ancient and contemporary knowledge by Māori for Māori and non-Māori communities (Smith et al, 2016).

Smith's book Decolonizing Methodologies gets to the heart of these tensions, highlighting:

“...acknowledging that scientific research has long been a tool to dehumanize Indigenous peoples. One of the problems, explains Smith, is that the methodologies and methods of research, the theories that inform them, the questions which they generate and the writing styles they employ, all become significant acts which need to be considered carefully and critically before being applied. In other words, they need to be decolonized..." (Smith, 2008, p.39).

This doesn't mean a total rejection of western theory and research, but more so a 'centering' of Māori concerns and worldviews from a Māori perspective and purpose.

Understanding why Māori have a deep-rooted 'distrust of research', which has "dehumanized Māori and privileged western ways of knowing", provides the context and shift towards "developing Indigenous methodologies - A kaupapa Māori research" (Smith, 1996). She goes on to explain that a kaupapa Māori approach to research attempts to retrieve space and achieve three general aims: to convince Māori of the value of research for Māori; to convince powerful research communities of the need for greater Māori involvement in research; and to develop approaches and ways of carrying out research. To some extent the approach taken in this thesis embraces Smith's aims and provides practical evidence on how this can be achieved. 
These tensions have paved the way for kaupapa Māori research to employ a range of methodological approaches and constructs that draws from traditional and contemporary knowledge bases. Pūrākau (traditional Māori narratives) and maramataka (the Māori lunar calendar) are two such examples that challenge and navigate knowledge politics in ways and means not previously possible. They are expressions of mātauranga Māori comprising epistemological constructs, cultural codes and a suite of techniques empirical in nature (Hikuroa 2017, Lee 2009). It would make little sense for Māori to 'dabble' in validity and reliability when it came down to survival of an iwi. Western science, pūrākau and maramataka all follow the tenets of scientific evidence and methodology and, according to Hikuroa (2017), this is both accurate and precise.

Open and persistent challenging of the research community on racist practices and attitudes, ethnocentric assumptions and exploitative research, sends a clear warning that research communities must conduct research with Indigenous communities that is underpinned by the understanding that "our views do count and our lives do matter" (Smith et al, 2016). By adopting a kaupapa Māori approach, researchers must ask of themselves and Indigenous communities such questions as: Whose research is it? Who owns it? Whose interests does it serve? Who will benefit from it? Through to: Is their spirit clear? Do they have a good heart? And, are they useful to us? Ultimately, these tensions serve to expose inequalities and discrimination, whilst simultaneously holding all researchers to account ensuring Indigenous knowledge, and indeed mātauranga Māori is obtained for the benefit of Māori whose decision it is to use it in ways they deem necessary.

The title of the thesis by Tauwhare (2008), 'Dancing at the interface' discusses the harms done to Indigenous knowledge and mātauranga Māori since colonization, but also speaks to the opportunities for Māori to lead the development of a new way of knowledge production in Aotearoa New Zealand, capitalizing on and complementing the traditional richness of both knowledge baskets. Tauwhare visualizes the many styles of dance, likening this to multiple events and exchanges occurring at the interface. He alludes to a collaborative interface requiring mutual respect and acknowledgment of what each basket brings with the potential for new knowledge. This process begins with korero with manawhenua through wānanga, kanohi ki te kanohi, and historical reports and records. 
This current thesis also attempts to 'dance at the interface' between two knowledge baskets. The tensions and potentialities highlighted in this current section have been considered in developing the methodology for my research, which is outlined next.

\subsection{Methodology}

\subsubsection{CASE STUDY: LAKE MOAWHITU}

This study connects to manawhenua on many levels, and indeed layers, through mātauranga Māori (Māori knowledge) and whakapapa (genealogy). The intent is to trace and symbolise 'ngā haerenga' (the journeys) of both Ngāti Koata and tuna back and forward in time to the present day as a means to visibly connect people and tuna to the whenua and their roto (lake), the focal point of this thesis. The whakataukī (expressed in various ways), 'Kia whakatōmuri te haere whakamua' provides a Māori perspective on how the dimensions of time; past, present, and future, are intertwined. Within this cosmic movement, time has no restrictions - it is both past and present (Tse et al., 2005, cited in Rameka, 2016). Māori see the past and present as knowable, and so are viewed as in the forefront of human consciousness, whereas the future cannot be seen and therefore is conceived of as 'behind' (Walker, 1996). With this, "the individual is conceptualized as walking backwards in time to the future, with the present unfolding in front of them as a continuum into the past." This whakatauki depicts a person carrying one's past, including the mana of their tūpuna into the future. For Ngati Koata, this concept highlights their role and responsibility as kaitiaki to contribute and implement the mātauranga and moemoeā (aspirations) of their tūpuna towards restoring the mauri to their roto.

With the rapid decline in water quality and tuna population (as will be revealed later in this chapter) at Lake Moawhitu, the combined voice of the people heard from wānanga, kānohi ki te kānohi, and taken from historical accounts provides a clear statement of intent to restore Lake Moawhitu to its mahinga kai status whereby cultural harvesting of tuna could once again be practiced. This intent includes a commitment to actively engage and support the existing research projects and studies currently underway (Ngāti Koata, DOC and Lakes380) adhering to specific kaupapa Māori (mātauranga Māori) and modern science methodology. Collectively this process involves the accurate collation of information through a range of methods 
including extraction and analysis of sediment samples, application of cultural heath assessments, and wānanga in order to generate meaningful results for implementation.

The threefold goal for Ngati Koata regarding Lake Moawhitu is to: (1) monitor and identify, through sampling and assessment, the causes of water degradation and tuna population decline in the lake; (2) to restore the mauri of the lake, and; (3) restore a sustainable mahinga kai practice as a means and way to express kaupapa tuku iho. Kaupapa tuku iho are the values gifted to us by tūpuna Māori and have endured a shifting cultural landscape over the last 200 years, and continue to remain prominent (Spinks, 2019). The purpose of this thesis is to contribute to the collective goals representing the voice of the iwi. For this reason the thesis adopts a dual kaupapa Māori and Western Science research approach that would identify and support meaningful and effective recommendations by stakeholders to restore the mauri of Lake Moawhitu and achieve a restored mahinga kai site for future sustainable cultural harvesting of tuna by manawhenua.

\subsubsection{NGĀTI KOATA IWI CONNECTIONS TO TUNA KI MOAWHITU}

Ngāti Koata attachment to Lake Moawhitu and to tuna transcends a physical connection. Layers of intergenerational experiences, knowledge and whakapapa are 'embedded in a tapestry that interweaves Ngāti Koata tikanga, kawa, and heke (journey/migration). A Māori worldview affords a connectedness to everything that is living and non-living and includes ways of knowing, feeling, and doing (Taonui, 2011). This same reasoning therefore recognizes tuna as having their own unique link to place, and indeed, ways of knowing (Potangaroa, 2010).

Tracing the origins of Koata and 'how they came to be' at Lake Moawhitu, requires an understanding and acknowledgement of the relationship between manawhenua and tuna in the context of mahinga kai. Koata origins began elsewhere and was a one-way heke, like that of heke tuna (migrating tuna). Ngāti Koata have their origins hundreds of kilometers to the north on the western coast at Kawhia, in the Waikato region. It is here that their ancestors arrived in Aotearoa c.1400 AD on the waka, Tainui. Several generations later, Ngāti Koata takes its name from the ancestress Koata who was born c.1617. Koata had two sons, Kawharu and Te Wehi, however, it was the union of Kawharu with Waikauri of Ngāti Toa that connected the interwoven whakapapa lines between the two iwi (Adkin, 1948; Simcox, 2003). 
As history notes, the prevailing inter-tribal tensions towards the end of the $18^{\text {th }}$ and start of the $19^{\text {th }}$ centuries escalated to battles involving alliances of kinship, which turned into an arms-race with the arrival of European whalers and explorers with their muskets. Ngāti Toa was the dominant tribe at Kawhia along with their kin Ngāti Koata and Ngāti Rārua. At this time, Ngāti Toa were in a precarious position in their relationship with neighboring Waikato and Maniapoto iwi. By contrast the prospect of gaining lands in the south and making contact with Europeans for trade and musket acquisition (Adkin, 1948; Simcox, 2003 p.19) had been revealed by the 1819 allied 'tauā' (war party) that travelled as far south as Horowhenua and Whanganui-a-Tara. Ultimately, the Kawhia alliance of iwi were forced to make a hasty retreat from their ancestral homelands. This initially involved two distinct heke: Te Heke Tahutahuahi, the fire-lighting migration from Kawhia to northern Taranaki; and Te Heke Tātaramoa, the bramble-bush migration from Taranaki to Wellington. With reliance on kinship from Maniapoto enemy lines, and under the fighting leadership of Ngāti Toa chief, Te Rauparaha, their heke took many 'twists and turns' as they negotiated safe passage to their new homeland on the west coast of the lower North Island, eventually seizing and settling on Kāpiti Island. Many, particularly kaumātua and tamariki perished on their southern heke. Ngāti Koata, along with allied iwi were based at the northern end of Kāpiti Island, while Ngāti Toarangātira were located at the southern end of the Island. It was at the northern end of the Island, in the early hours of the morning, that Koata were alerted to a surprise allied attack involving the local resident tribes along with the Kuruhaupō allied tribes from Te Tau Ihu (the northern region of the South Island). The enemy attack was repelled, however, a Ngāti Koata boy named Tawhi had been previously kidnapped by the Kurahaupō alliance of tribes, that included Ngāti Kuia who were at that time based on Rangitoto ki te Tonga.

When it was discovered that Tawhi had been taken to the south to Rangitoto ki te Tonga, it was the Ngāti Kuia chief, Tutepourangi who, after suffering heavy defeat and to avoid certain death himself, took Ngāti Koata chiefs, including Te Putu and Te Whetu, to Rangitoto. There, upon safe return of the boy, Tutepourangi ceded, or 'gifted' (tuku) a vast amount of the region, including Rangitoto ki te Tonga to Ngāti Koata. History tells us that Tutepourangi had little choice but to cede; the alternative option for Koata would have been to take Te Tau Ihu by conquest (raupatu). This would have meant certain death for Tutepourangi and many of the inhabitants of Rangitoto ki te Tonga in the 1820s. Perhaps Koata could see that through 
intermarriage, growth and prosperity could be achieved by leveraging local iwi connections, including mātauranga iwi (the knowledge possessed by Ngati Kuia).

It has been said that Tutepourangi specifically gifted a lake (roto) to the Koata chief and tohunga, Te Whetu, at this or at a subsequent time i.e. Mo-A-Whetu (for Whetu) is perhaps what we know today as Lake Moāwhitu.

So it can be seen that Nga heke o Ngāti Koata, like tuna, was a one-way journey taking the iwi to a place in the 1820s that bore the fruits for settlement and growth. One of these fruits was peace, so Rangitoto ki te Tonga was a place, after a long, perilous, and arduous heke, that Ngāti Koata had been hoping for. Leaving their ancestral lands from the north, with their fate unknown, made this heke even more fortuitous. One could say, it was a heke built on sheer determination to survive. The renowned Ngati Koata mata-kite and mareikura, Wetekia, may tend to believe it was a heke built on faith (ngākau pono). Rangitoto ki te Tonga became their new home, a place for their posterity. That the Ngāti Koata tohunga and chief, Te Whetu, was gifted a significant ecological roto, renowned for mahinga kai, at a pivotal time in history gives meaning to the concept of tuākana - teina connectivity between tuna and Koata. Through a Te Ao Māori lens, as the significance of Lake Moawhitu comes to light, it is this connection that gives insight to a multi-dimensional relationship between tuna and Koata; from whakapapa, kaitiaki, sentinel, food source, and heke, to that of a mutual respect for the 'Other' from time immemorial. The historical presence and importance of tuna was valued by Ngāti Koata. Heke tuna and the return of their offspring was known and sustainably fished by iwi, hapū and whānau (Pätete, 1997). Like heke Koata, heke tuna are long and perilous, mature tuna leaving the safety of their roto before journeying thousands of kilometres to the north, within the cradle of Tangaroa, never to return, yet knowing their offspring will. Māori knew the time and conditions (maramataka) in which the offspring of tuna would return to the shores of Aotearoa to take up their place as the next generation, as kaitiaki/sentinel and as a sustainable food supply for Māori, "tuna a tātou taonga - a gift from the gods."

\subsubsection{KAUPAPA MĀORI RESEARCH METHODOLOGIES}

For this thesis, a kaupapa Māori methodological approach was employed to explore and understand cultural values and objectives from manawhenua in relationship to tuna at Lake 
Moawhitu. Other data gathering methods include the collation of literature from iwi sources relevant to cultural harvesting of tuna at Lake Moawhitu, including historical reports.

Kaupapa Māori methodologies are qualitative methods that were used to collect and gather data, including a wānanga (a gathering for discussion) and kānohi ki te kānohi (face to face) interviews. Further, the intention was to undertake a haerenga and wānanga ki Moawhitu, whereby I planned to accompany Ngati Koata kaumatua on a field visit to their traditional mahinga kai site. Unfortunately, Covid-19 restrictions curtailed the kaumātua haerenga and meant a lost opportunity to hear their impressions and memories triggered by their presence on the island. I was however able to make several visits to the Island myself, one of which was for the purpose of extracting sediment cores (for eDNA, pollen analysis, and hyperspectral scanning), assessing tuna health from Lake Moawhitu, as well as glass eel recruitment. As these haerenga were part of my own heke, helping to develop my own connection to Moawhitu, they are relevant to the kaupapa Maori methodology of this thesis, as well as contributing to the biophysical science research. Ethics approval was obtained 16 May 2019 from Victoria University of Wellington to ensure the methodological approach was ethical, obtained the relevant consents by participants, and was culturally aligned to the kaupapa of knowledge sharing.

I facilitated a wānanga with Ngāti Koata on Thursday 7 June 2019 that took place at the Ngāti Koata Trust office (137 Vickerman Street, Nelson). The wānanga was video recorded and subsequently transcribed to inform and identify the specific themes and cultural value findings applied in section 4.5.

We opened the wānanga with karakia and mihi whakatau in keeping with Ngāti Koata tikanga. Ngāti Koata whānau members who attended the wānanga included:

- Rangi Elkington (Kaumātua) and his wife Sharon Elkington

- Rawenata Gieger nee Elkington (Kuia)

- Pirihira Paul nee Elkington (Kuia)

- Marlin Elkington (Ngāti Koata Customary Advisor)

- Louisa Paul (Ngāti Koata Cultural Advisor) 
- Ammon Katene (Ngāti Koata Communications Manager)

- Rosemary Hippolite (wife of the late John Hippolite)

- Russleigh Parai (Ngāti Koata kairangahau, Masters akonga, wānanga facilitator)

- Dan Moore (Department of Conservation)

Kānohi ki te kānohi / face-to-face interviews were also conducted with:

- Tiwini Hemi (Elkington) (Kaumātua) - kānohi ki te kānohi, April 2019 conducted by Russleigh and Joanna Parai

- Puhanga Tupaea nee Hemi (nee Elkington) (Kuia) - kānohi ki te kānohi, May 2019 conducted by Russleigh and Joanna Parai

- Harry Elkington (Kānohi ki te kānohi, June 2019 conducted by Russleigh Parai)

The majority of the participants had grown up on Rangitoto ki te Tonga from the 1930s to 1950s before departing Rangitoto for further employment or educational opportunity. Each of the participants had varying degrees of experience either fishing in general and/or hì-tuna at Lake Moawhitu.

Wānanga participants were guided through a range of questions (Appendix $A$ ) that were structured thematically to prompt discussion around specific issues such as whakapapa, connection to whenua, connection to roto, hī tuna (tuna catch practices), kaitiakitanga, and impacts on and aspirations for tuna at Lake Moawhitu. The kaumātua and kuia namely the Elkington siblings were in turn able to synergize and recall significant strands of historical knowledge leveraging the methodology of wānanga. Wānanga provides the vehicle for the expression of whanaungatanga and the opportunity for the interweaving of many perspectives and whakaaro. The whakaaro (thoughts and memories) of kaumātua and the way in which they make meaning of their experiences generates knowledge about specific sites, events, what, how and why they were taught certain skills, from weaving, to fishing, to handling a waka (boat). Compared to kānohi ki te kānohi (one of one interviews), wānanga creates a synergistic environment for the potential of the sum of knowledge generated, i.e the whole, to be greater than it's individual parts. 
Face-to-face interviews were conducted by myself (Ngāti Koata, kairangahau) along with my wife Joanna (daughter to Tiwini Hemi and niece to Aunty Puhanga Tupaea). They were both conducted in the participant's homes, with immediate whānau present.

Three Ngāti Koata kaumātua were interviewed: Tiwini Hemi, aged 84 years old, in April 2019; and his elder sister, Puhanga Tupaea (nee Hemi) aged 87, in May 2019. It is important to note that while some methodologies rely on a fair and representative sample of participants to provide balanced and qualitative perspectives across a broad spectrum, a kaupapa Māori approach can rely on one or two voices of significance to carry or communicate the will of their tupuna. So, it is with Puhanga, Tiwini and the Elkington siblings who provide that voice. The interviews with Puhanga and Tiwini helped to draw out their relationship to their Kuia (grandmother) and mareikura of Ngati Koata, Wetekia (and Raatapu John Arthur Elkington (mātua whangai)) and the knowledge surrounding her. From their homes at Wharariki and Madsen Bay, to mahinga kai at Moawhitu on Rangitoto ki te Tonga. Tiwini was tamaiti whangai (a child adopted by or gifted) to 'Wetekia' and Raatapu from the age of six by his parents. The reality is Tiwini's parents had little choice, Wetekia claimed him.

To illustrate this relationship Puhanga explains:

Tiwini .. he was different, he was theirs (his grandparents, Wetekia and Ratapu), if you know what I mean, much to the chagrin of my Dad. My Dad came to pick him up because we were going to live in Canvastown, and Grandma put her hand on him (Tiwini) and said "this one is mine"...he didn't argue. I was barely 6 , he passed away when I was 7 (my dad, Jim Haami). I think Tiwini was her (Wetekia) heart. She would go out to the bush for parmanack. She was a hard working lady, She was a fisherwoman. She was the voice of the tribe and the power behind the tribe (Interview with Puhanga Tupaea, May 11, 2019).

I interviewed Harry Elkington in August and September 2020. Each interview took approximately two to three hours (with frequent breaks) and followed a semi-structured set of interview questions (see Appendix 2), although lines of questioning sometimes diverged to either clarify a point raised by the interviewee or to focus on a specific area of expertise. All interviewees were video recorded with consent granted verbally at the start of each interview. Interview recordings were later transcribed and advised that Ngāti Koata Trust 
Office would hold these records. Each interview was conducted according to tikanga, starting with karakia and mihimihi. This set the foundation for engagement and acknowledged the whakapapa of the interviewee. Interviews took place at the home of the interviewee. Whānau members were present at some interviews to tautoko and support the interviewee.

Both methodologies are powerful mediums of knowledge transmission. From aTe AoMāori approach the experience activates the senses to connect familiarity in face, sound, smell, and touch through a warm embrace between whānau and kairangahau. Through my journey of connection to my iwi, Ngāti Koata, the opportunity to make that link at wānanga came indirectly through 'other' significant whanaunga to the wānanga participants, they being Tiwini and Puhanga (who were unable to attend the wānanga due to Covid-19).

Sharing my whakapapa with my Koata whanaunga was one thing, but merely mentioning my immediate relationship to Tiwini (through inter-marriage) and recent visit and interview with aunty Puhanga, was another. The Elkington sibling's faces especially lit up as they had all grown up together on Rangitoto ki te Tonga and shared more than familial bonds. The doors were flung wide open for me and trust was immediately granted. The medium of knowledge sharing through wānanga was instantly made practicable. Wānanga has the potential to be less effective where trust is not established which stems from lack of familiarity (of the kairangahau, Māori or non-Māori), too much familiarity (Māori know only too well), lack of transparency and communication (who are you, what is your purpose, what is the information for, what do the participants/iwi obtain from this exchange)? Disadvantages for kānohi ki te kānohi is relatability between participant and kairangahau. How well do they connect, is there cultural, language, age, maturity and transparency barriers? The one to one interview can also bring out strong emotions which if not facilitated right can be upsetting for all involved, including immediate whānau. Applying correct tikanga, attended by open and honest kairangahau is key to ensuring these knowledge sharing methodologies and experiences are effective and meaningful for all.

The contributions from kaumātua and kuia is significant particularly considering the many who have passed on, ki ngā mate o Ngāti Koata me ngā iwi Māori, haere, haera, haere atu ra. They who have left a legacy of whānaungatanga, kaitiakitanga, and wairuatanga. I take a 
moment to acknowledge you ... you're knowledge, kindness, love and laughter are cherished memories, never to be forgotten.

Common beliefs, values, and knowledge were shared, which in the context of these interviews and wānanga recur through a Māori worldview (Te Ao Māori). As concepts, it is necessary to caution: "They are best understood in the context of the language and the culture they are derived from. To reinterpret these meanings into the English language by its very nature loses significant context and meaning" (KTKO Ltd, 2005, cited by Tipa, 2009).

\section{HAEREnga to RANGitoto KI TE TONGA -}

Lake Moawhitu is representative of a large proportion of lakes in Aotearoa New Zealand where it seems that the impact of significant water degradation on fish species has occurred in a relatively short period of time. Lake Moawhitu was renowned as a mahinga kai site for Ngāti Koata due largely to its capacity to carry a huge tuna population. As such it was important to visit this lake on several occasions to assess current stock levels of tuna including their weight, length, and health. Developing a DNA assay to specifically detect the long fin tuna required another visit to take core sediment samples from the lakebed for the purpose of DNA analysis. Although down-core DNA tuna results were not available in time for this thesis completion, this core was used to undertake pollen, hyperspectral and microbial DNA analyses (Chapter 3 ) to determine what had been occurring within the lake catchment over time, and more importantly why?

I visited Lake Moawhitu on five separate occasions since commencing my own heke researching tuna. The dates, purpose and activities engaged in were as follows:

- December 2018 - Tuna and water quality monitoring with Cawthron Institute and DOC, setting fyke nets and G-minnow traps to assess fish species and specifically tuna health, stocks and proportion of long to short fin in both the wetlands and lake

- September 2019 - Lakes380 lake-bed sediment coring for historical analysis of lake catchment, which included a visit with the Project Steering Committee to assess wetlands and re-planting progress to date

- August 2020 - Glass eel monitoring and Wetlands native plant revitalization programme (Ngāti Koata and DOC joint project) 
The DOC - Ngāti Koata Project, which was largely focussed on lake and wetland ecosystem remediation was already making progress towards this objective. Working alongside KoataDOC Project Manager Dan Moore (DOC) I was able to see first-hand the rising water levels in the adjacent wetlands, one of the mid to long-term aims being to enhance tuna habitat, health and population.

\section{HISTORICAL REPORTS / IWI SOURCES:}

Nga Ture Kaupapa o Ngati Koata ki te Tonga, c 1820-1950 (2000), a report by Heather Bassett and Richard Kay, commissioned by the Crown Forestry Rental Trust, includes excerpts of interviews conducted by Ngāti Koata historian Josephine Paul in which several iwi kaumātua shared their knowledge on hī-tuna at the lake based on first-hand experiences. Their accounts provided a baseline on the state and stock of tuna health and numbers. They also shed light on cultural harvest practice, including the migratory months for tuna, their abundance, as well as the tikanga surrounding mahinga kai and kaitiakitanga and why this practice is important to manawhenua.

A similar report, Te Tau Ihu Mahi Tuna - Eel Management Plan (1999) provides detail on the various methods of hī-tuna, maramataka (the calendar for hi-tuna) and the whakapapa of tuna. These reports provided valuable information in support of the findings from wānanga and interviews conducted, providing valuable background to this chapter

Further material, including images and maps from 'D'Urville Island (Rangitoto ki te Tonga) in the Northern South Island', a report commissioned by the Waitangi Tribunal, (Pätete, 1997), and other iwi and DOC sources were used as reference points at both wānanga and kānohi ki te kānohi interviews to compare with the current state of Lake Moawhitu and adjacent wetlands. The material served to stir memories and illicit emotive comments about the current condition of the lake compared to their recollection of when it was cleaner and full of tuna.

Finally, in this thesis I use the term knowledge basket and knowledge stream. They mean much the same thing but are not exactly the same thing. When I use knowledge stream it is much more about the flow and process of knowledge whereas the basket is more about the storage of and repository for knowledge. 


\subsection{FINDINGS: CULTURAL VALUES AND VIEWS EXPRESSED BY NGĀTI KOATA MEMBERS}

This section presents the key evidence and findings from the various sources described in the previous section (4.2). These results are presented in sections (5.1 to 5.5) that relate to the five key themes outlined below, with the rationale for each theme explained at the beginning of each section. The distinction between evidence and findings is somewhat arbitrary, but is made with the aim of separating original information obtained from the various data sources (evidence) from the interpretation of that evidence in terms of the key five themes (results).

This section is organised thematically to explore:

1. The importance of whakapapa to interviewees and wānanga participants; how they connect to Ngāti Koata, and what is their link to tuna?

2. Whanaungatanga - Place-centred connections to Rangitoto ki te Tonga and Lake Moawhitu; where they grew up and/or their earliest association with Rangitoto ki te Tonga; their work/family role; significance of place names and their meanings; wāhi tapu; childhood memories.

3. Mahinga kai of tuna; tikanga and mātauranga with respect to tuna specific to Ngāti Koata that have been handed down from their tūpuna; what is still practised today.

4. Te Ao Hurihuri - Kaitiakitanga: observations of environmental, social and cultural changes to Lake Moawhitu and to tuna populations; kaitiaki issues and concerns.

5. Te Moemoeā, Mauri and Wairua: aspirations, hopes/dreams and priorities for the health, wellbeing, mauri and sustainability of tuna for the future.

Despite this explicit thematic structure, it is important to recognise that these themes are interwoven with one another, consistent with the broader concept of matauranga. Thus some findings are pertinent to multiple themes and so repetition and complexities are inevitable. Further, I use 'connection to Moāwhitu' and 'connection to place' interchangeably, however 'place' refers to Rangitoto ki te Tonga and by association, Moāwhitu, whereas 'connection to Moāwhitu' makes reference specifically to the lake site. 


\subsubsection{THE IMPORTANCE OF WHAKAPAPA}

\section{Rationale}

One of the key themes that came out of the wānanga and interviews was the many ways in which whakapapa was referred to and applied. Ngāti Koata kuia Puhanga Tupaea (née Hemi) shares her perspective on how she connects to tūpuna and Rangitoto ki te Tonga through whakapapa:

I whakapapa through Wetekia who was a Ruruku from d'Urville Island. Her husband was John Arthur Elkington from Porirua, so my grandfather is Ngāti Toa and my grandmother is Ngāti Koata and Ngāti Toa. Rangitoto is placed close to Pelorus, my father's people are, well, are from Canvastown, Wairau, Havelock. It was easy for Te Rauparaha to come down and go through all of those seaways to come into d'Urville Island (Interview with Puhanga Tupaea, May 2019).

Whakapapa provides meaning to all things including the link for Koata to place, lake, and tuna. Māori abide by basic tenets when it comes to relationships with the animate and inanimate as well as other aspects of creation (Tipa, G. 2009; citing Te Rūnanga o Ngāi Tahu, 2001). "The core of these relationships reflects the fundamental belief that all things are linked by whakapapa which descend from Papatūānuku and Rangi (the Earth Mother and the Sky Father)" (Tipa, G. 2009; citing Te Rūnanga o Ngāi Tahu, 2001). To Māori, they see themselves as much a part of their environment as other fauna and flora species, including the biotic world (Tipa, 2009, p 100).

A Te Ao Māori worldview connects events, species, and the inanimate in ways not typically considered through a western science lens. A Māori worldview affords a wider scope and an integrative approach, the benefit arguably providing a whole ecosystem perspective. Mātauranga captures this perspective akin to the sum of the total (a Te Ao Māori subjective and holistic view) being greater than the sum of its parts (a western science objective and reductive approach).

Whereas western science might detach at that point and just look at a single species (e.g. tuna or heke tuna (migrating tuna) in isolation, within a Ngāti Koata framework heke tuna is conceived and connected in a myriad of ways. By drawing on heke tuna as a pūrākau to 
describe heke Koata (the migration of Ngāti Koata) serves to reinforce their understanding of the precarious nature of the heke experienced by both tuakana (tuna as the older sibling) and teina (Koata as the younger sibling). So these two heke are tightly woven together.

\section{Evidence}

Kaumātua Tiwini Hemi provides an insight into the importance of spiritual and instinctual connections that draw both people and tuna to place:

Tuna, like all Māori food, everything, land was held as sacred, as a living and breathing thing. Nowadays people look at land as an acquisition in a monetary value rather than a spiritual value. Māori in fact many people [cultures] hold burial places very sacred, where their relatives are buried. It's like the eels that migrate, they have an instinct to want to be or go somewhere else [back to their place of birth], like our ancestors where a lot of our whānau [and] offspring want to come back to their homeland (Interview with Tiwini Hemi, April 2019).

Koata historian, Josephine Paul, provides further insight:

Retaining and maintaining tribal links was significant to my great grandmother Wetekia Elkington (nee Te Ruruku). She would travel north, from her home on Rangitoto ki te Tonga to reconnect with her relations living within the Tainui, Waikato region. Through her grandmother, Uhiwaero, from Port Waikato, she had close links to Te Whare Kahuiariki. As such she would stay and spend time with Te Puia Herangi. It was on one of those visits that Wetekia was presented with a cloak and two pounamu, named Parehauraki and Parewaikato. The strength of their connection was displayed when, Te Puia in return travelled to Rangitoto ki te Tonga to reside for a while amongst her whānaunga.

Like the tuna, those journeys were the beacon that drove and inspired the need for my great grandmother to return to those places and people of significance despite the distance. Being with and connected to all those endearing familiarities, provided her with validation, a sense of belonging, sustenance, and strength to navigate life. 
Heke Koata provides a constant reminder to Koata of their past, their tūpuna, and the perilous journey they endured to ultimately arrive at Rangitoto ki te Tonga. Without the foresight and determination of their forebears, Koata may only be a remnant of the size it is today. Tiwini gives his perspective on heke Koata:

Heke Koata tūpuna never lost their relationship with Waikato, ever! We've got his [Kingi Tawhiao] cloak and Parewaikato and Parehauraki, it was given to my grandma [Wetekia] and grandpa [John Arthur Elkington] by Te Puia. They went back to Waikato. In 1978 or thereabout, they [Waikato] came back for the other stone which was given back into family possession (Interview with Tiwini Hemi, April 2019).

Reflecting on a spiritual level, Harry Elkington a descendent of Wetekia provides another perspective regarding the purpose of heke tuna which sees the sexually mature tuna return to their place of 'birth' thousand of kilometres north in the Pacific Ocean to continue their whakapapa, their ancestral line. So it was, suggests Harry, with Koata members who:

..upon settling at Rangitoto ki te Tonga returned to their homeland in the north to remnants of their iwi at Kawhia, Port Waikato, and Raglan, to reunite or settle with their kin in keeping the bloodlines strong" for their offspring and generations to come. The son of Ruruku was Matiu who returned to the Waikato from Rangitoto ki te Tonga and married. "They went to Raglan and their posterity remain there through to today." "This is like the tuna," explains Harry (Interview with Harry Elkington, 2019).

This view suggests that tuakana and teina, albeit on separate heke, return to that place that gave life, their ancestral homeland.

Uncle Rau Tupaea and Aunty Puhanga are both descendants of Matiu and Roma respectively (Matiu and Roma Hoera are Ruruku brothers)." "That marriage was arranged. This is significant because the travel that goes back and forward continues the kinship" explains Harry. They may leave their birthplace, but they will always some day return (Interview with Harry Elkington, 2019). 
This inference to whakapapa creates a form of mātauranga because of its significance to Māori. This resonates with Māori in a way that links tuākana to teina, as well as connecting their past and present to future aspirations through rangatiratanga. Like heke tuna, Puhanga returned to the greater Waikato, the homeland of her tūpuna. There she wed, settled, and built a legacy founded on whanaungatanga.

\section{Findings}

These observations from Ngati Koata kaumātua underline the bonds of kinship through whakapapa between Koata and Waikato, which can also draw on the (heke) migration of both tuna and Koata (tuakana and teina): tuna back to their wāhi tapu homeland in the Pacific and Koata to Kawhia and the greater Waikato. Their destination may be final, but their posterity would be forever connected by time and place. This is mātauranga Māori, through a Te Ao Māori (worldview) lens which is just one way in which Māori understand and make meaning of significant events and relationships. Māori look at the whole way in which the tuākanateina relationship exists, acknowledging that tuna are tuākana (the older sibling) and Koata are teina (the younger sibling). There are many ways in which Māori understand or perceive this relationship, however the way that Ngāti Koata understand that entanglement is whakapapa.

Whakapapa is not simply 'ancestral lineage', but includes all the experiences, pūrākau, karakia, waiata and mōteatea which contribute to a growing intergenerational repository of mātauranga. If you trace this back, you will return to its origins - that being whakapapa. This circular pattern of thought, connection, and 'making sense of it all' once again links to the whakataukī, "Kia whakatōmuri te haere whakamua" - opening our minds to their world and their way of thinking that brings meaning. Māori walking backwards in time to the future with their eyes fixed on their past depicts how each dimension of time is intertwined. The natural manner in which this way of knowing is conceived and applied could in and of itself be regarded as a supernatural phenomenon. Tohunga had the gift of seeing, and as a seer could travel through time to speak with their tūpuna for guidance in preparation for battle, for hunting and fishing, or when an entire iwi were about to embark on a perilous heke. 


\subsubsection{THE IMPORTANCE OF WHANAUNGATANGA AND CONNECTIONS TO PLACE}

\section{Rationale}

While whakapapa establishes a person's standing and identity, whanaungatanga explains relationships (Carbaugh, 2007). These relationships also connect people to place and can be described and passed down in a number of ways. Such connections to Rangitoto as through birthright, whakapapa and intergenerational experiences links to the principle of whanaungatanga which is linked to kinship and interdependence between all things, including people, within the natural world (Crengle, 2002). Whanaungatanga is built over time, and as such is cross-generational. In my whanau we are constantly reminded of the hì tuna summer expeditions we shared along the Kaptiti coast, including the transfer of knowledge from my koro to my dad at Pauatahanui and what this means to our whānau.

\section{Evidence}

The value of Rangitoto ki te Tonga is connected to whanaungatanga with its array of experiences and embedded emotions that such memories evoke. According to both Puhanga and Tiwini:

I was born there [...] It's home, it's where we grew up (Interviews with Tiwini and Puhanga respectively, April and May 2019).

Wānanga participants (i.e. the Elkington siblings Pirihira, Rangi and Rawenata) responded similarly:

It's home, the home of our parents, grandparents [and] their parents. It's always been home (wānanga, June 2019).

Puhanga shared her childhood memory of Rangitoto ki te Tonga: "The earliest memory I have embedded deep in my whakaaro of Rangitoto is I was born on d'Urville." She explains her connection to the Island in the following:

I believe d'Urville Island was first the homeland to some of my father's ancestors, and my father. My grandmother [Wetekia] lived there with her father, and she fell in love 
with John. She was only fourteen at that age and I believe not long after that she was wed. Wetekia married John Arthur Elkington. She was a powerful lady, she was the voice of the tribe, she was the power behind the tribe (Interview with Puhanga Tupaea, May 2019).

Puhanga shared her childhood memories of Lake Moawhitu:

It [Moawhitu] was next to the sea, I was about seven or eight. I would go with grandpa and grandma. It was a brilliant life! I see whānau, I see my dad working. I got the impression we were at the lake to look for kai [food] (Interview with Puhanga Tupaea, May 2019).

Tiwini shares a similar memory:

My grandmother Wetekia was walking when she first took me there (to Lake Moawhitu), in the early 1940s. My dad died about 1940, I was at Wharariki... While we were there, she [grandma] became crippled and never walked again. So there was just me and grandma, grandpa and Joe. When people came over, every time they came over, one time we'd go off for a couple of days and eel [at the lake] (Interview with Tiwini Hemi, April 2019).

Both Tiwini and Puhanga highlighted the significance of Rangitoto as a place where everyone knew everyone. Residents shared everything and could go anywhere from "...the Kawharu homestead to the Rene homestead, from Madsen Bay on one side of the Island to Wharariki on the other side". Tiwini explained:

We'd go over to Wharariki to do the shearing with my grandma [Wetekia] and grandpa [Ratapu], Waha and Joe. It had to be after rain that we'd go because the eels would come down out of the Lake (Moawhitu) into the creek (Interview with Tiwini Hemi, April, 2019).

\section{Findings}

At wānanga Ngāti Koata kaumātua reminisced about days gone by. Compared to kānohi ki te kānohi, wānanga meant the Elkington siblings, whanaunga, and spouses were able to draw from each other's experiences to shed more light on the kaupapa being discussed. Wānanga 
provides the vehicle for the expression of whanaungatanga and the opportunity for the interweaving of many perspectives and whakaaro. The whakaaro (thoughts and memories) of kaumātua and the way in which they make meaning of their experiences generates knowledge about specific sites, events, what, how and why they were taught certain skills, from weaving, to fishing, to handling a boat. Like the relationship between heke tuna and heke Koata, whenua (Rangitoto) is similarly intertwined with its people through activities such as mahinga kai.

Whanaungatanga is about what, how, and why they do the things they do as iwi and whānau towards strengthening whānau bonds. Despite the relatively recent arrival of Ngāti Koata to Rangitoto, they brought with them entrenched ways of doing, based on ways of knowing. This knowledge enabled a continuity of their practices in their new-found home. This is significant for Koata on Rangitoto as it presented a new opportunity to recreate what was their traditional way of life, their relationships, even intergenerational stories reinforcing this principle called whanaungatanga. Tuku (gifting) of Rangitoto ki te Tonga by Ngāti Kuia provided Koata the local knowledge they needed to assimilate and transition into their new environment as manawhenua. Therefore, the mātauranga timeline is not bounded by the number of generations that have contributed directly to the knowledge surrounding a particular place. Ngāti Koata also drew upon mātauranga from their past (in Kawhia) to generate new knowledge as they adapted to a new environment. A Māori worldview connects people to place (Rangitoto ki te Tonga) through shared intergenerational activities and experiences and, as such, they cannot be separated.

Tying whānau, place, the elements (e.g. rain) and tuna together in these whakaaro reflects a holistic, even multi-faceted approach to understanding and explaining the experiences of whanaungatanga through mahinga kai and vice versa. When I was young I looked forward to going eeling at traditional sites, or setting the net out in Pari-rua (now known as Porirua) harbour, or heading over our maunga down to Wairere to gather kaimoana. On reflection, these experiences were about time with whānau as much as it was about the actual activity of gathering kai. This created the whole whanaungatanga experience drawn from mahinga kai. At Rangitoto, this mahinga kai experience contributes to the expanding body of mātauranga which extends to what whānau value about the Island and why. It informs which are the types of activities whānau continue or need to continue to practice as an expression 
of their connection to their whenua (land). Such activities include customary harvesting of tuna which Lake Moawhitu was renowned for. What comes through from wānanga and interviews is the adoration participants hold for their whānau, parents, koroua and kuia that were centred around mahinga kai (hī-tuna, hī-ika).

\subsubsection{MAHINGA KAI - CONNECTION TO MOAWHITU}

\section{Rationale}

Mahinga kai means 'food works' or the work of gathering food at specific sites. This term encompasses access to kai; the site where kai gathering occurs; the act of gathering, preparing, and distributing the kai; and the good health of the kai (Tipa, 2009). Upon arrival on Rangitoto, the survival of Koata was dependent upon knowledge about where food was located and how best to gather it. Puhanga shares her account:

Moawhitu was, to my parents, a very special place, [and] to my grandparents... because of the kai that was in it. It was access to it [the kai] (Interview with Puhanga, May 2019).

Drawing from Ngāti Kuia's 'food' (knowledge) basket speaks to the transmission of knowledge as local intelligence was passed onto the iwi from Kawhia.

\section{Evidence}

Te Tau Ihu Mahi Tuna - Eel Management Plan (1999) provides detailed traditional methodology on hī-tuna (catching tuna) and when this took place (i.e. according to maramataka, the lunar calendar), and how Māori in Te Tau Ihu (the Top of the South) whakapapa to tuna, i.e. our relationship to tuna. Some of these methods were mentioned and described at wānanga. Through this medium of research, wānanga established the lines of whakapapa between Koata and Kuia. Raupatu (gifting) served to bring immediate reconciliation between the two iwi back in the 1820s which through inter-tribal marriage and inter-generationally tied iwi, tūpuna, and mātauranga together. The connection of the two iwi meant that the inter-generational knowledge of sustainable tuna harvesting that came with Ngati Koata, was able to be applied to their new place for mahinga kai at Moāwhitu. The following comments from Koata kaumatua give vivid expression to the practice of mahinga kai that ensued at Moawhitu. 
James Elkington, Ariana Rene, Alfred Elkington and Puhanga Tupaea described how eels were taken and their importance in Ngāti Koata's customary economy (Interviewed by Josephine Paul, 19).

Moawhitu was renowned both for the size and quantity of tuna, as Tiwini affirms: "I've heard ducks have been pulled under water by duck-loving eel." At the wānanga, Rangi adds: "No we didn't go in (to the lake), the eels were too big. They were huge (using his hands to show how big they were)."

The following is a detailed account by Puhanga describing how and why Koata fished tuna:

And you know the tuna? Huge! The tuna was known to migrate, go seasonally to lay eggs. But the tribe knew where the tuna was and they would go out and they didn't go out to get one, they went to feed four or five families [Elkington's, Hemi's, Hippolite's and the Selwyns according to Tiwini] in the Bay so it would be two or three days to go and collect kai [because it is the winter supply of food]. You'd see it all strung up on the line. So they were gutted from the anal cavity, gutted, [...] and hang them on the line, and when they were dry you'd put them in pig fern. I didn't pawhara [to gut and fillet tuna], just the men. They were very well at preparing kai for great big families. The pig fern was a place to dry, access to the air. Pig fern is like fine leaves [nothing like flax]. Slime was taken off with the grass.

Yes, skin turned black after the drying process. It was opened up then laid upon each other in pig fern, the head was eaten independent coz they'd take the body and then cut it down to the anus and open it and either put a bracken fern strand to keep it open and hang out in the sun.

Nothing was left out in the moon. Sometimes our tūpuna would tell us something just to shut us up [laughing] but I'm of the opinion that there would be moisture in the air, but the sun would dry it out and it would close the fish up (interview with Puhanga Tupaea, May 2019).

Hī-tuna (catching tuna or tuna harvest) demands that Māori possess a deep and broad knowledge of the tuna population, health, size, colour, life cycle, and varieties/names of the tuna in Lake Moawhitu. For example, at the wānanga Pirihira makes the distinction: 
Aunty Hazel said one colour tuna came from Moawhitu and another colour came from Te Puna (Wānanga, June 2019).

In adapting to their new environment at Rangitoto, Koata would adjust their practices for hītuna. This generation of new knowledge, leveraging on 'old' knowledge, was based on observation and experimentation which resulted in modified methodology. An example is shared by Rangi Elkington:

I'd go fishing with my dad (Rangi Elkington Snr), fishing for tuna out of the Lake [Moawhitu]. [We would] dig channels and holes, we'd put kelp in there, they'd come down where the kelp was and I guess they'd sense the kelp and think they were in salt water and not move out of the hole. We'd just pull the kelp up and pick up the tuna (Interview with Rangi Elkington, June 2019).

Mahinga kai involves all aspects of catching, gathering and collecting food. For example, the Te Tau Ihu Management Plan (1999) highlights several historical eeling methods traditionally used by tangata whenua to catch or harvest tuna. Rapu Tuna - Digging in swamps and bogs for tuna that (during the summer dry months) burrow in and hibernate where the soil is wet. Matamoe is the name of an eel which does this. From what Koata kaumātua and kuia have shared, this practice encompasses all this and much more by linking to whakapapa and whanaungatanga. Referring to his tūpuna, Tiwini explains:

They had a reverence towards mahinga kai. It was handed down from father to son. When we went to catch eels, the best way to catch eels was with a spear. That's what they did and so that was what we learnt. And it had to be raining (Interview with Tiwini Hemi, April 2019).

The traditional Māori lunar calendar is called the maramataka (the turning of the moon), guides which nights are particularly good and which nights are not so good for eeling and fishing. This was reinforced and supported by other forms of embedded knowledge based on environmental conditions, such as the whakataukĩ: He ua ki te po, he Matamoe ki te ao-Rain at night, Eels at dawn. Matamoe, also referred to in the previous paragraph, is one variety of migratory tuna that is specific to Te Tau Ihu, including Lake Moāwhitu (Te Tau Ihu Mahi Tuna 
(1999). This form of mātauranga i.e. whakataukī, reinforces this specific environmental knowledge and associated practice.

Tuna would also be plentiful in the wetlands, as Tiwini reported:

You couldn't see them [tuna] because with us [kids] tramping around, the water became muddy. But Uncle Rangi [Rangi Elkington Snr] would be there on the bank with his spear and he'd just be poking it in there because they'd be streaming out of this hole down this little narrow creek and you'd feel one, flick it up the bank (Interview with Tiwini Hemi, April 2019).

The channel trap, known in Te Tau Ihu and by Koata as Kohumu (Koumu), was extensively used from February to May as migrating eels congregated in a specific location in an attempt to reach the sea. At the wānanga, the Elkington siblings shared their memories of hĩ-tuna:

The tuna harvest was when they migrated out to sea, [in] March [and] April, then [in] July [and] August for the bigger tuna. The later season was when you'd see the bigger ones crawl across the sand to get to the sea. They were usually the ones that missed the high tide. When we harvested we go over the hill and stay at Wharariki then go around to go eeling. I remember we went out at daytime, but I remember also at night time going to eel when they were on the move (Wānanga, June 2019) .

\section{Findings}

The evidence above gives ample expression to the rich cultural practice that had developed around hī-tuna at Moawhitu that must have been sustained for several generations at least. An objective view may look at the practice of gathering food as separate to the intimate relationship Koata has to the site. However, in a Koata worldview, gathering kai was inseparably connected to the people (whānau) and the place (Moawhitu) and here, perhaps, lies the key for sustainability. From a Ngāti Koata perspective, an objective or fragmented view will miss the essence of what this combination of place, practice, and people means. This is a Ngāti Koata way of making sense or meaning of it all: emphasising mahinga kai as a holistic, life-sustaining practice based on whanaungatanga and kaitiakitanga. As such, the mantle of custodian, protector, guardian and steward is key to ensuring that respect and mauri is upheld by maintaining a sustainable and balanced ecosystem. 
Mahinga kai demands an intimate and deep understanding of methodology including maramataka in relationship to tuna life-cycle, life style, their characteristics/traits and how these align to the Māori lunar calendar for hunting and gathering kai. This all speaks to the interwoven nature of knowledge, practice, and whakapapa which feed into and reinforce each other when it comes to relationships with tuna.

But it is more than this, the experience acknowledges mauri and wairua and the principle of reciprocity. Māori being the apex predator in the food chain nonetheless understood their status in relation to tuna and as such, through kaitiakitanga, practiced sustainable harvesting. And through whakapapa understood the tuākana-teina relationship. This connection between Māori and tuna perhaps transcends a western science perspective to the study of tuna. However, it may also provide insight and respect for the relationship through a shared lens. Mahinga kai continues to evolve as new technologies and new ways are applied, however the principles of whakapapa, whanaungatanga, kaitiakitanga, mauri and wairua underpin this traditional discipline.

These findings effectively reflect the epistemology of mātauranga Māori through the generation of new knowledge which, in the case of Koata having migrated to Rangitoto, they had to vary, adapt, and add to their methodology for hi-tuna whilst leveraging the intimate knowledge held by local tangata whenua, Ngāti kuia. In this way, mātauranga was continuously accumulated and applied through the practice of kaitiakitanga. This Indigenous knowledge was not fixed static, or only 'traditional', but is adaptive, expansive and evolving whilst drawing on the past.

\subsubsection{KAITIAKITANGA AND TE AO HURIHURI: the CHANGES to LAKE MOAWHITU AND tHe tUNA POPULATION}

\section{Rationale}

Kaitiakitanga applies to the interaction with ecosystems by kaitiaki (Tipa, 2009) who are empowered (rangatiratanga) and obligated through whakapapa. This refers to the cultural practice of maintaining balance within nature which is based on reciprocity or respect when interacting with the environment (Tipa, 2009). While mahinga kai and whanaungatanga 
brings significant meaning to Koata, kaitiakitanga encompasses these principles as the iwi endeavours to come to terms with recent changes in the mauri of the lake as well as collective efforts to restore its ecological balance.

\section{Evidence}

Tiwini explains:

This demonstrated a sustainable approach by Koata to minimise wastage of their catch (Interview with Tiwini, April 2019)

This was reinforced at wānanga by Rewanata as she recalls:

..but they all taught the same thing, only take what you need (Wānanga, June 2019).

This again points to the sustainable usage of their catch, suggesting also the potential imbalance that may ensue given a lack of respect shown within these relationships. Participants all spoke of tikanga (values and traditions) they had learnt from their parents and tūpuna, where respect was shown in acknowledging their relationship to tuna through sustainable hi-tuna.

By adopting a whole ecosystem approach, kaitiakitanga is more than guardianship by specifically appointed people; it is a community (iwi-hapū-whānau) driven ethos. Kaitiakitanga for Koata participants is proactive engagement by all, a shared responsibility, as they interact within the Lake Moawhitu ecosystem to maintain a sustainable tuna population built on respect [for tuākana]. This is their understanding and illustrates how Koata have historically implemented this whole ecosystem approach to sustainability.

This knowledge, which has evolved through observation and experimentation, was used to protect their territory and the resources within it. Kaitiaki became adept at interpreting signs of changing ecology in the environment, and had a duty to protect their natural world (Tipa, 2009). In the wider context of habitat, tuna at Lake Moawhitu were historically both healthy and abundant. Puhanga describes as follows: 
The Lake was clean, there were lots of birds, swans. It was beautiful (Interview with Puhanga, May 2019).

Tiwini also has vivid recollections of the state of Moawhitu:

We never drank out of it, there was a stream that fed the lake, it's where they got the water from, it was always running. Running water is the water you use. The lake water was good, rocky in some parts, not big rocks. There was raupō along the banks (interview with Tiwini Hemi, April 2019).

When shown a map (Fig 16 - see below) of the lake Moāwhitu in 1923, wānanga participants remembered when the wetland was all lake, connected to what is Lake Moawhitu today.

Yes, 'cause we'd come in [row in] from Wharariki and go straight into there [pointing to the access point into the wetland]. It was deep, the wetland was all lake and the water level was the same all the way through, but shallower in between i.e where the lake and wetlands meet (wānanga participants, June 2019).

In a report commissioned by the Crown Forestry Rental Trust for Ngāti Koata, Moawhitu Reserve was created in 1895 as a fishing easement to an inland lagoon. This meant Ngāti Koata could access their traditional mahinga kai site for cultural harvest and all year fishing of tuna despite private ownership of the surrounding land. Oral historian, Josephine Paul identified Moawhitu as being a significant food gathering (mahinga kai) site for Ngāti Koata, stating:

It was valued so highly that tribal members would row from Whakapuaka to Moawhitu for the specific purpose of eeling. Access was never an issue until late" (Bassett and Kay, 2000).

However reclamation of the wetlands for pastoral use in 1948, which had previously allowed initial access to the reserve from the Greville Harbour shore, now made this customary fishing site increasingly difficult to get to. From this point the water level in the wetlands and adjoining lake receded, resulting in reduced tuna habitat and poor water quality in the Lake (Fig. 16, below). Grazing cattle, the use of pesticides and superphosphates continued to degrade this significant customary fishing site for Ngāti Koata (Bassett and Kay, 2000). 


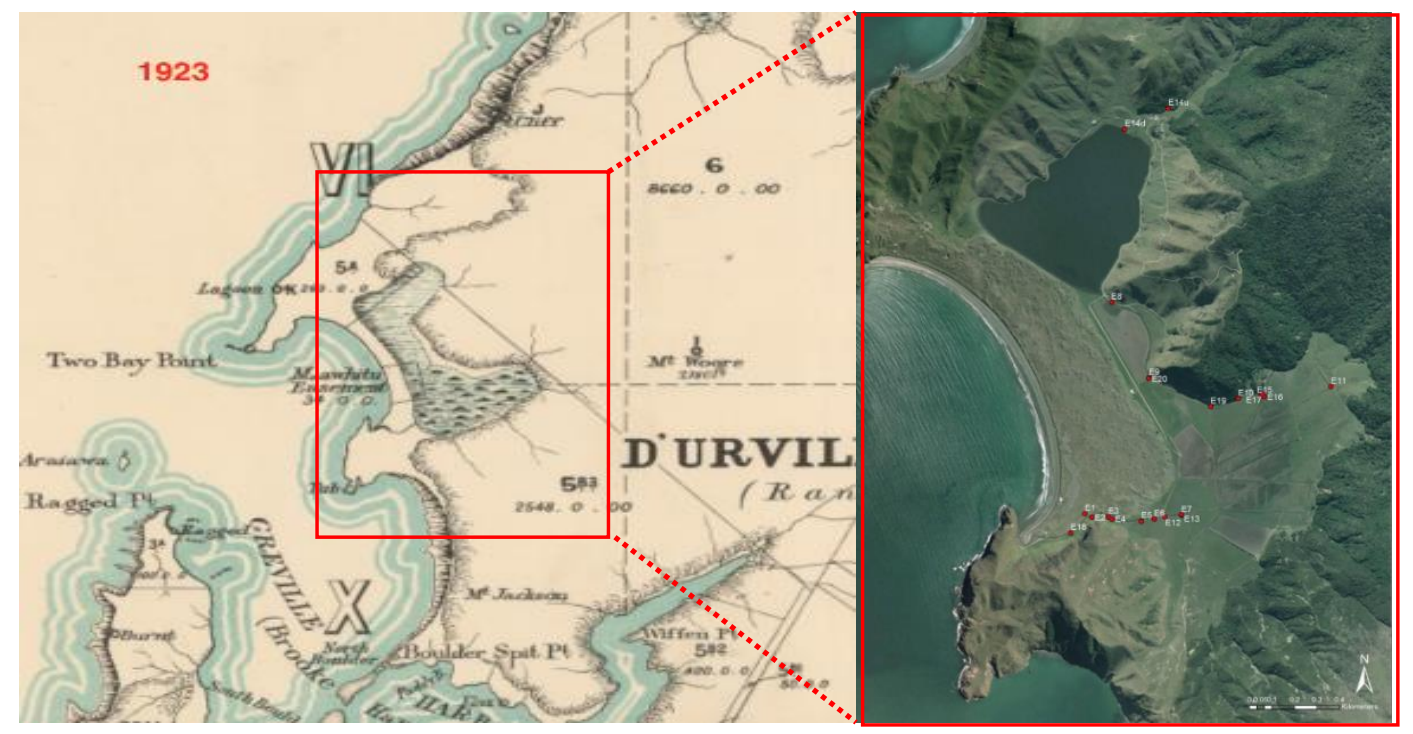

Figure 16. Left: A 1923 maps of Lake Moawhitu and adjacent wetlands

Right: Lake Moawhitu today, showing the drained lake and wetlands (Drinan, 2018)

Figure 16 shows the sites where fish and invertebrates, including long and short finned eel were previously recorded at Lake Moawhitu and Greville Harbour (from 1-4 December by McCaughan in 2014), several decades after the draining of Lake Moāwhitu and adjacent wetlands (Drinan 2018). The impact from draining the Lake had a direct impact on traditional harvesting of tuna from 1948 (Bassett and Kay, 2000, Pg 38). The biophysical evidence (Chapter 3) also indicates detrimental effects to the ecosystem over the past several decades which aligns to land use change.

At wānanga some of the participants acknowledged the change in land use during their lifetime from their traditional mahinga kai site to, as ownership changed hands, the draining of the lake for conversion to pastoral land from 1948.

This adversely impacted mahinga kai practices but more importantly their ability to perform their role as kaitiaki. Kuia Pirihira recalls:

I don't remember swimming in the lake cause the cattle were in it (Wananga, June 2019).

According to Rangi Elkington:

It was after the draining of the lake to create more pastoral land that the eeling dropped away. We didn't go out then, from about the early'60s. 
Rosemary Hippolite also shares her observations at the wānanga:

Rangitoto was a place that was dear to John's [the late John Hippolite] heart. It was home to him and we went down there often and it fed him, but we see the capacity to eel down there is reduced.

Comparing the state of Lake Moawhitu today (see Figures 4.5 and 4.6 showing algae blooms on the lake between 2018 and 2019) and how it used to look, Puhanga who has not seen Moāwhitu for decades comments: "Why is it so polluted? What caused it?" This was a similar concern shared by all those who live remotely and haven't seen 'their lake' for many years.
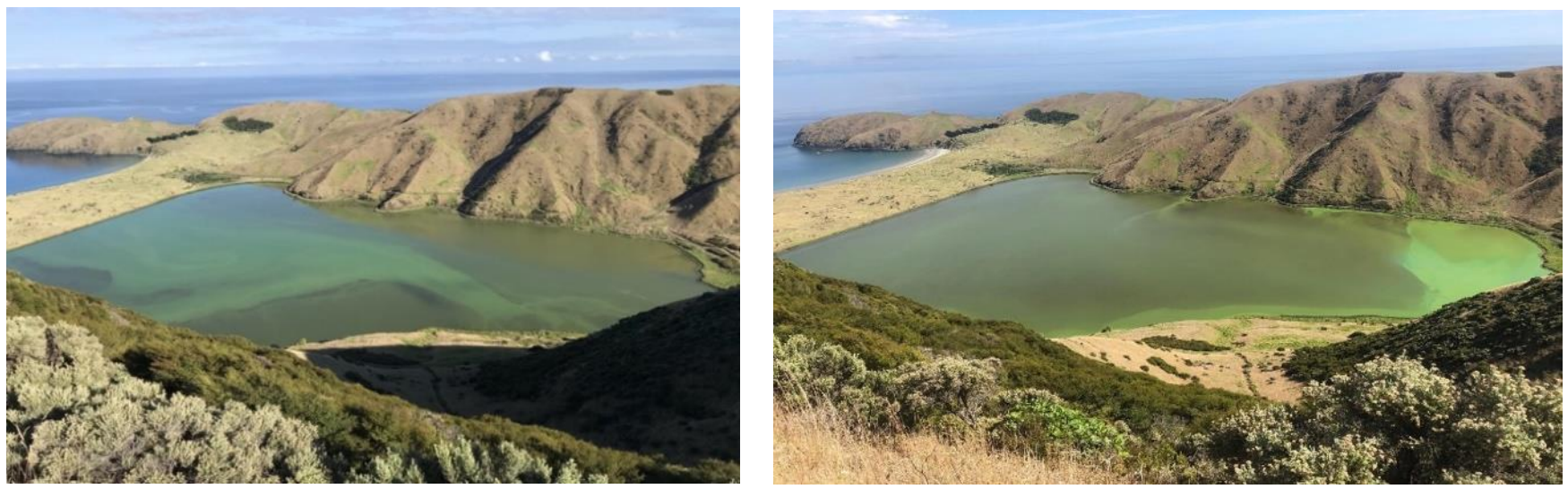

Figure 17: Lake Moāwhitu evidence of algal blooms in summer for both 2018 and 2019.

The above images (Fig 17) show consistent algal blooming over 2018-2019, however these blooms and their link to poor water quality in the Lake extends to the previous two decades since monitoring commenced and despite this site having transitioned from farming to a recreational reserve through the Heritage Society. These recent blooms indicate that this transition alone is not enough.

The restoration aspirations at Moawhitu involve not only restoring lake levels, but also planting local native vegetation communities that previously thrived at the lake margins and catchments. The pollen diagram presented in Chapter 3, using conventional western science methods, should be informative in this respect. However, presented as it is using formal (Latin) botanical terms, the information is not readily accessible to local people. To address this problem, my research has drawn upon consultation with Ngāti Koata, historical local documents (see Chapter 2), and other reputable sources (https://maoriplantuse.landcareresearch.co.nz/WebForms/PeoplePlantsFormat.aspx) to 
enable the Latin plant names to be translated to both the te reo Maori names that resonate with Ngāti Koata elders, as well as the common names in English (Table 2). This in turn has enabled the conventionally-formatted pollen diagram from Moawhitu (Figure 18) to be converted into a Māori version, enabling wider accessibility for Māori to the biophysical derived data. This example reflects a bringing together of two knowledge streams through knowledge transfer demonstrating how collaboration can work towards achieving common objectives. 
Table 2: Selective pollen taxa translated from Latin to Te reo Māori

Pollen

Botanical/ Latin

Common name

Māori

\section{Assemblage}

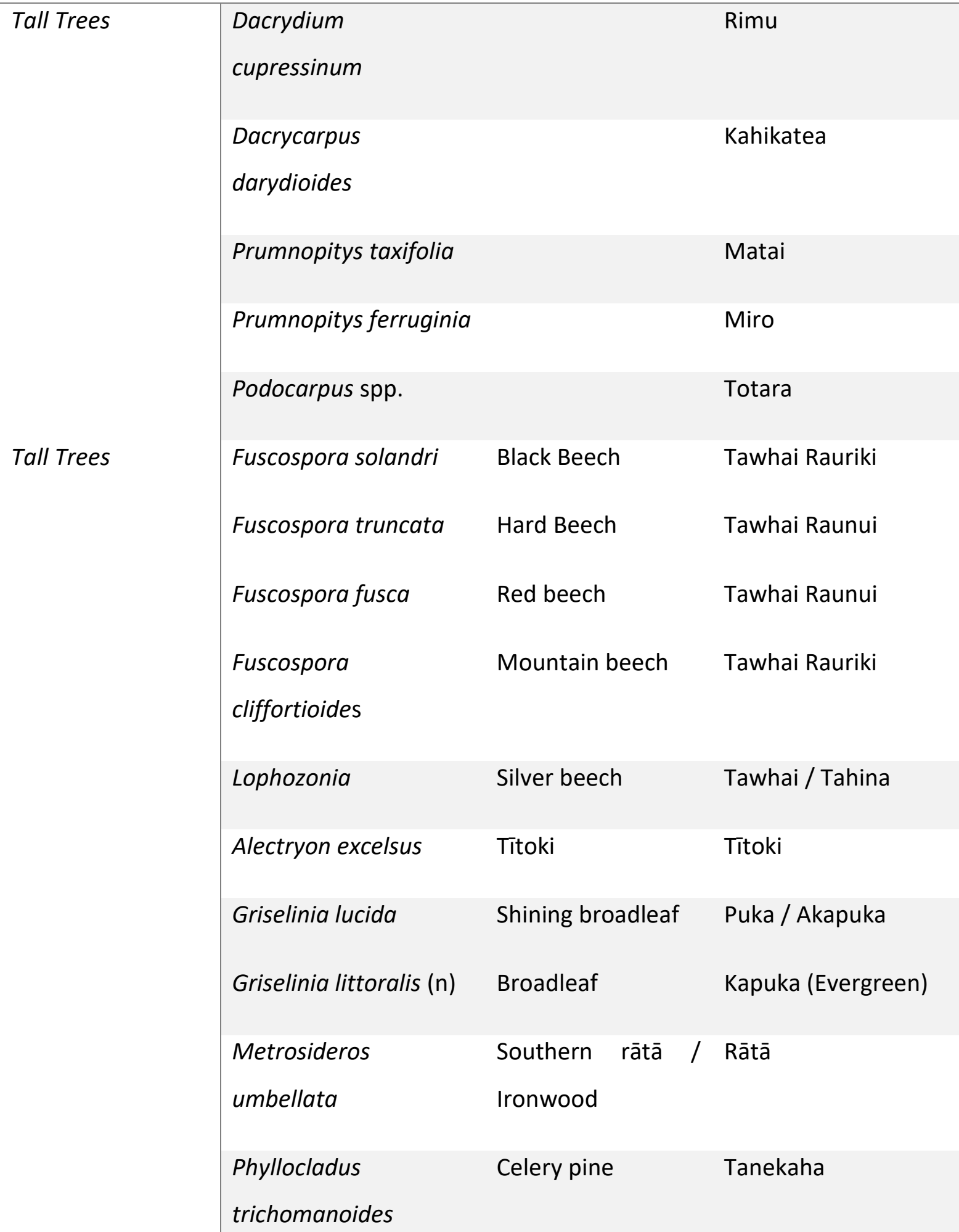




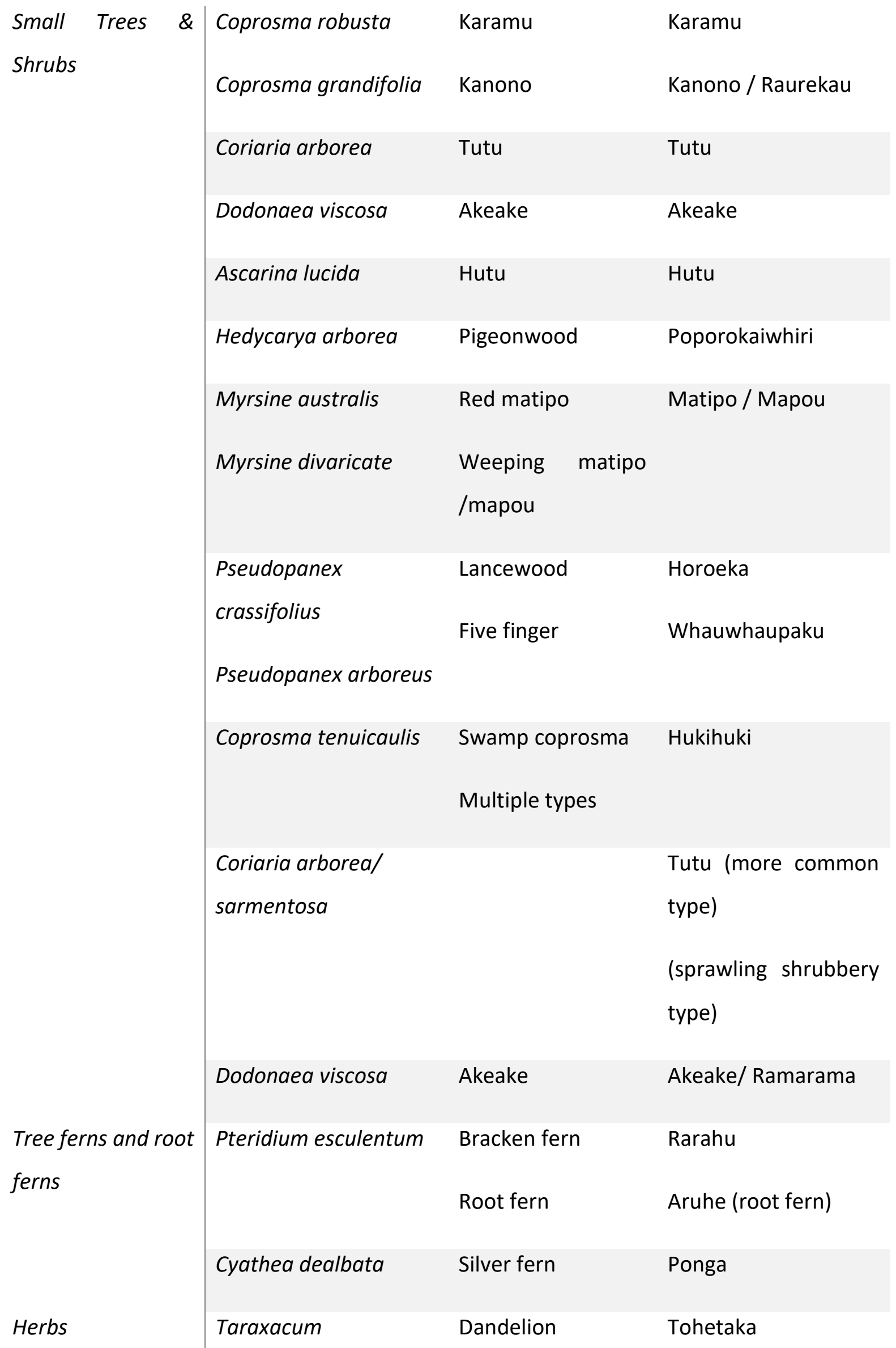




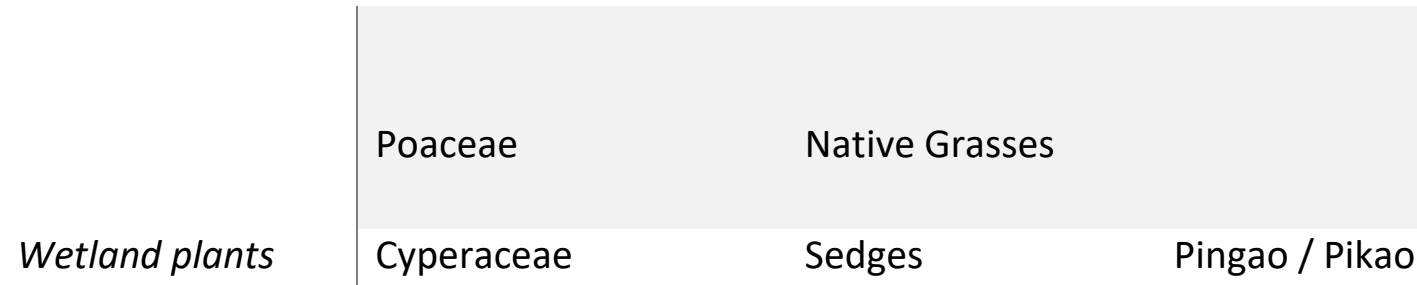

\section{Māori vegetation interaction}

The pollen record (refer chapter 3, figure 8) points to some possible ways in which local plant species may have been used in cultural practice. One such practice may have been the harvesting and use of Pīkao or pīngao, a native sand-binding sedge. This particular sedge was prominent in coastal lake dune systems and served to stabilize and prevent the sand dunes from shifting and eroding (DOC, 1992). However, evidence suggests the burning off and decline of this Pìkao during the European era (around the 1880s), brought the introduction of marram grass to perform the same role as Pīkao (Bergin et al. 1997). Pīkao, however, had many traditional uses and is considered by iwi as a taonga plant species for weaving and decorative appeal.

Harakeke (Phormium) and Rāupo (Typha) are two other examples of vegetation valued and utilized by manawhenua, Ngāti Koata. A particular species of harakeke (flax), known as wharariki is a softer type of the more popular, or common flax. It was used for clothing, thatching and matting, and was boiled and used as a medicinal plant to treat skin infections, burns, and internally for diarrhoea. Wharariki is also the name of a prominent bay, south of Moāwhitu, where the Ngāti Koata (Ngāti Kuia, and Ngāti Toarangatira) mareikura, Wetekia lived. They would paddle to the lake for hi-tuna (the eel harvest). Significantly, it is the identification of this traditional taonga vegetation that holds a historical connection for manawhenua to place, people, and tuna. 


\section{Pollen Plot Diagram - Vegetation translated from Latin to te reo Māori}

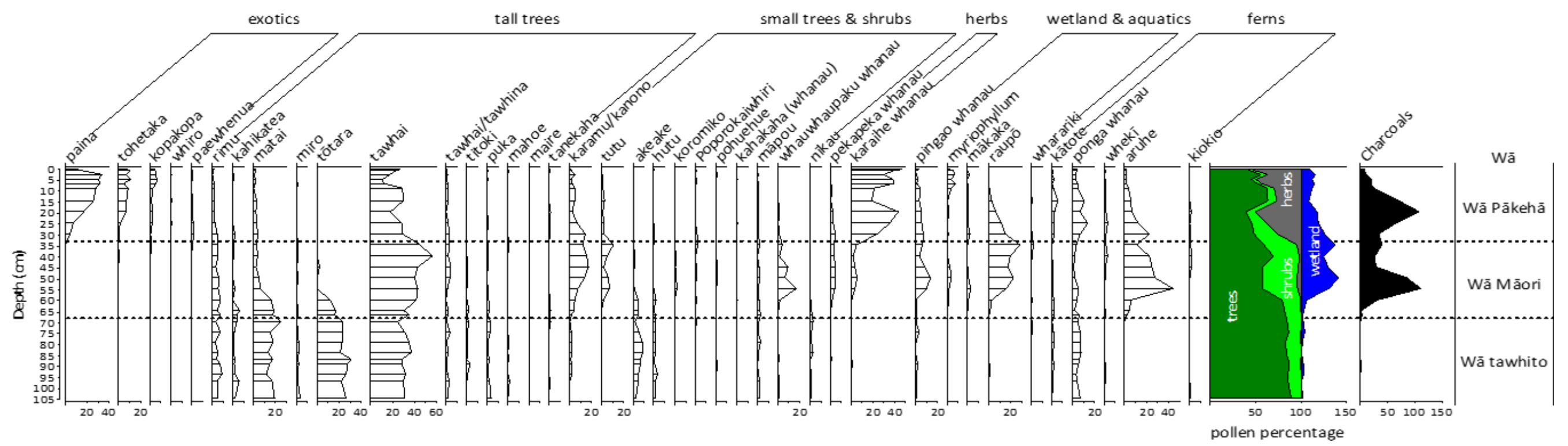

Figure 18: Palynology findings at Lake Moawhitu, vegetative names converted from Latin to te reo Māori 


\section{Findings}

Another key aspect of mahinga kai is that it is considered to be the principal indicator of environmental health of a natural system, which if under stress requires remedial action through monitoring, assessment and implementing restorative measures i.e. kaitiakitanga (Goodall, 2003). My personal haerenga into the lake and wetlands ecosytem has provided first hand observation and understanding contributing to the mātauranga basket. Tuna health and population has been significantly impacted. Also glass eel recruitment numbers appears to be significantly low, requiring consistent monitoring to establish recruitment levels during peak months. Leveraging two knowledge baskets, the biophysical and mātauranga, we have convincing evidence that the drainage of the Lake from 1948 combined with the intensification of pastoral farming would have marked a significant deterioration in habitat for tuna (and mahinga kai more generally).

Cultural health assessments $(\mathrm{CHA} / \mathrm{CHI}$ - appendix 2 ) and palynology results are methodologies that are being employed to address the historical value of tuna and inform the process of habitat recovery.

For example, the Maori pollen diagram (Fig 18) provides a medium for manawhenua to discuss, relate, and draw from. Planting of natives began two years ago under the DoC-Koata Wetlands Restorative '5-Year' Project, where harakeke, ti-koka, raupō, and other historically significant vegetation have been planted under this regenerative programme. Wānanga participants have referred to wharariki, raupō, and harakeke, including pig fern as those 'lifestyle' plants commonly used. Pikiao (sedges) were also used for decorative artwork e.g tukutuku panels and dying of piupiu. According to another Elkington sibling, Takuna Bayliss (nee Elkington):

Wharariki was also used for the purpose of making piupiu because it was shorter than harakeke and softer (Discussion with Takuna Bayliss, October 2019).

Raupō was identified by Tiwini as an important plant that provided habitat and sustained fish, including tuna, around the margins of the Lake. 
As highlighted in the next section, the impact to the Lake Moawhitu ecosystem through farming was devastating for both Koata and tuna alike. The disconnection from their mahinga kai site was pronounced. However, for Koata kaumātua and kuia who had grown up at Wharariki, Madsen Bay and other Koata settlement locales on Rangitoto, Lake Moawhitu is more than a place for gathering kai. It connects them to their mātua (parents), to koroua and kuia, tūpuna and the traditions and historical events generated through time - not the least being heke Koata and the subsequent gifting of Lake Moawhitu to Te Whetu. This speaks to Moawhitu as having its own identity, life force (mauri), and its own wairua.

\subsubsection{MAURI AND WAiRua - Aspirations fOR RESTORATION (TE MOEMOEĀ)}

\section{$\underline{\text { Rationale }}$}

Māori believe that all the living elements possess a mauri or life force (Marsden, 1992, cited by Tipa, 2009) and a spiritual essence or wairua, as well as a physical form (Barlow, 1991/1996). It is a special power derived from the supreme being (lo) that combines the wairua and the physical at birth, and at death the mauri is no longer able to bind these elements together. Lake Moawhitu, and the tuna within it, possess their own mauri and wairua. Māori respect this connection, and protecting the mauri of a resource is the fundamental management principle for Māori (Barlow, 1991,1996, cited in Tipa, 2009). This section speaks to the moemoeā (aspirations) for returning the mauri and wairua to Lake Moawhitu.

\section{Evidence}

Ngāti Koata as manawhenua are kaitiaki of Moawhitu. Despite relocations to far away places and transitions in land use, they understand in an ever-changing climate and world that everything has an order, a wairua and mauri. They understand also that some things have changed, including strict adherence to the old ways, to the kawa. Puhanga shares her views on these changes and the kawa (custom) practised by her forebears: 
Wetekia and Ratapu were staunch, and so was Te Ruruku, Te Huirangi, and Ben and Pene and uncle Son Turi, and uncle Rangi, they knew all the kaupapa. I'm of the opinion that to protect the kids from an overload of a mismatch between kawa Māori and kawa Pākehā, as we were emerging more into a Pākehā world, we were safer [i.e. by not knowing strict kawa] because there is something to answer for when you know the kawa and then you break it (Interview with Puhanga, May 2019).

Acknowledging these changes from a strict adherence to kawa (practices) to a synthesis of two world-views almost, enabled Koata to adopt and interweave new technologies and ways of doing into a conceptualised hybrid basket made up of new western knowledge whilst practising and safe-guarding their own knowledge.

My haerenga (journey) to Rangitoto ki te Tonga to study the Lake within the wider wetlands ecosystem drew from the recollections of kaumātua and kuia of a healthy place renowned for mahinga kai and linked to whanaungatanga. Their recollections contrasted to my observations, he mauri mate ahua (it [the lake] appears to have no life force) (Fig. 19). The deteriorated state of Lake Moawhitu and wetlands was pronounced and calls for significant remedial intervention. Understandably, analysis through a Te Ao Māori lens may be impossible - espistemologically and politically - for non Indigenous people.

The Koata-DoC Lake and Wetlands Restoration Project is a five year project based on consultation and collaboration towards implementing agreed and specific regenerative strategies targeting improved water quality, habitat, and native flora and fauna (Lake Moawhitu (Fig. 20). The recovery of Lake Moawhitu is directly connected to the wetlands restorative efforts, the success of which will have a flow-on effect by leveraging a restored wetlands filtration system. 


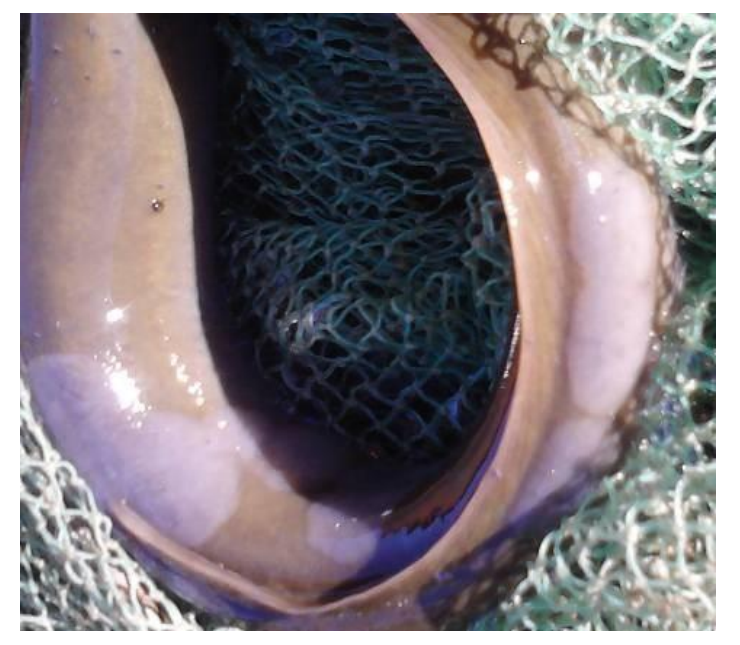

Figure 29: Fungal infection and parasite (circle) on a shortfin tuna caught in 2013 survey, links health of tuna to poor water quality
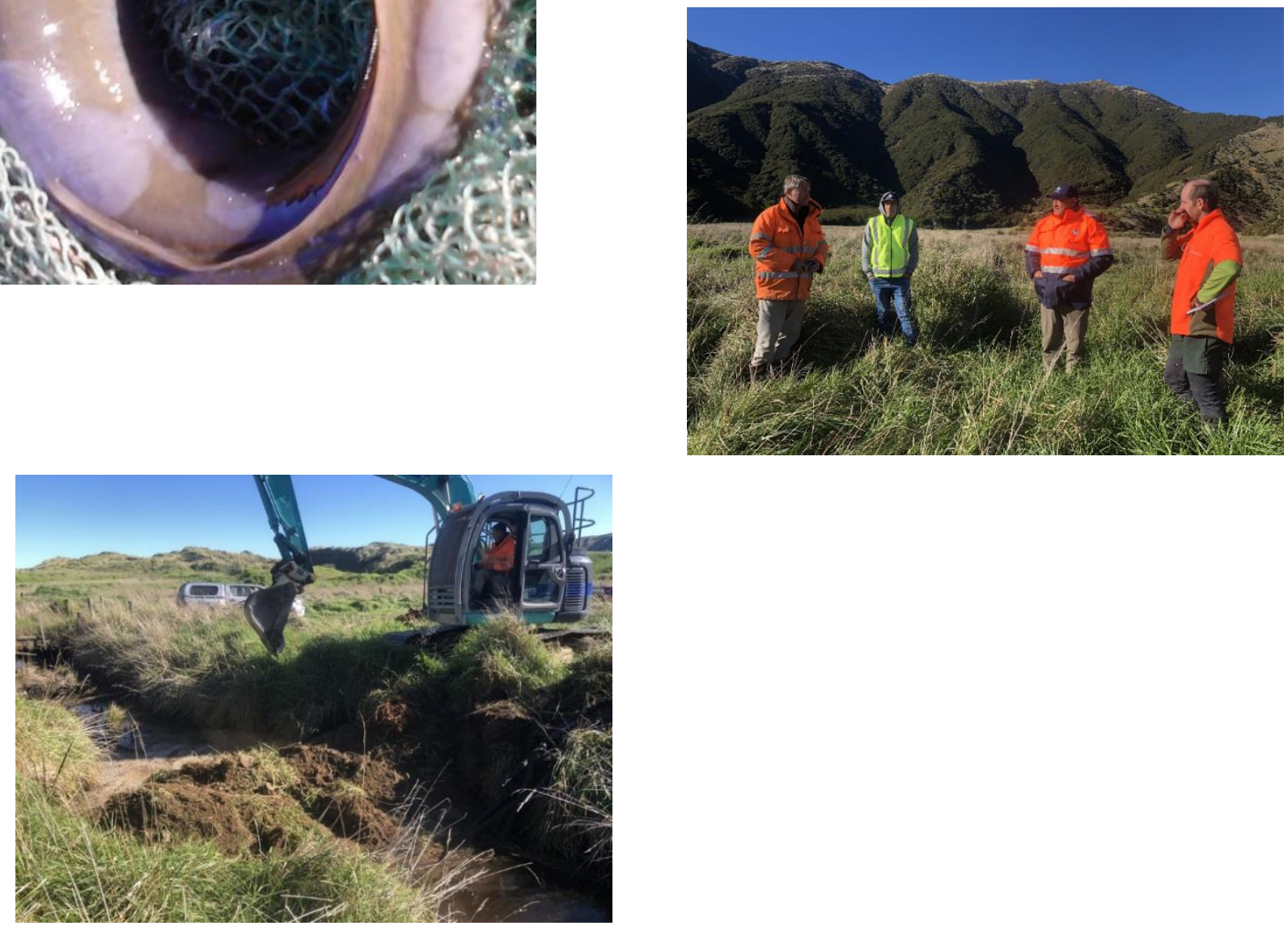

Figure 30: Koata and DoC also collaborate Wetlands restorative strategies (left) which included dam constuction on the main outlet channel (2018). 


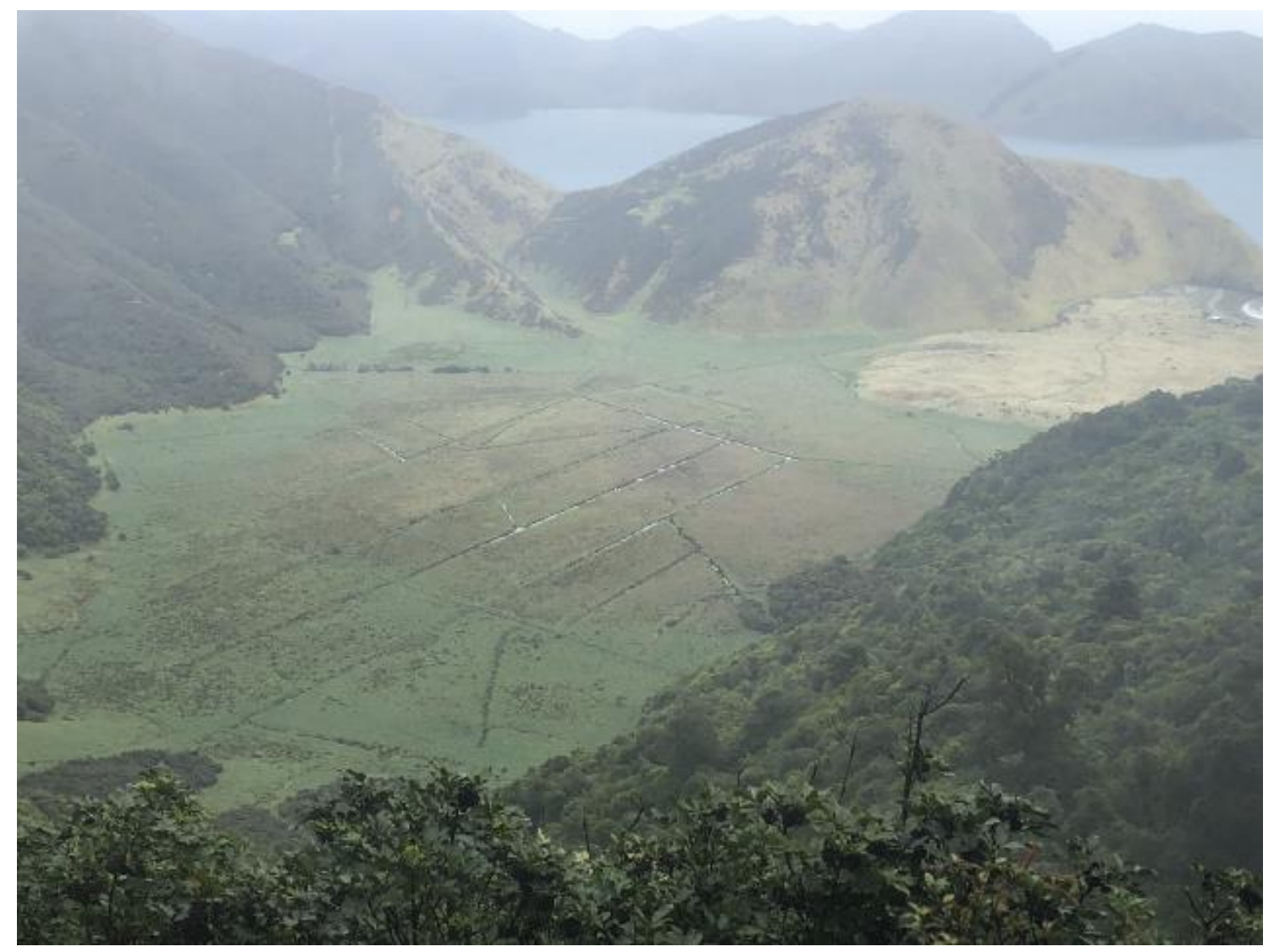

Figure 21 1: Lake Moawhitu wetlands complex

As kaitiaki and kairangahau (researchers), the ability to draw from specific methodologies and add to the repository of mātauranga as well as data collected and assessed by DoC over the past two decades (summarised in DoC report by 'Parai, 2019b') has combined to reinforce findings specific to tuna health, population, and baseline data for glass eel recruitment into the Wetland ecosystem (figs 21 and 22). This also serves to support and uphold kaitiakitanga. Determining a baseline of glass eel recruitment numbers into the wetlands and lake ecosystem is one objective where peak months for recruitment are being established with the support of NIWA, Koata-DoC and Lakes380. 


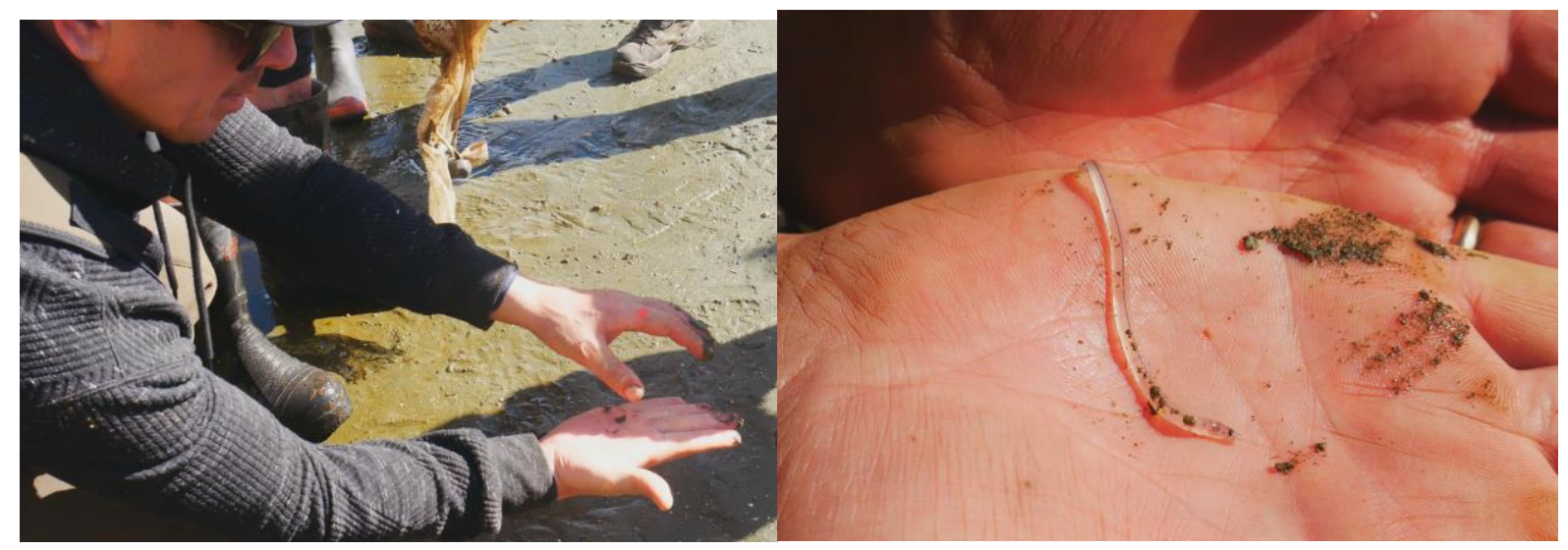

Figure 22: Lake Moawhitu wetlands inlet, where several glass eels were caught, assessed and released.

Recollections shared by all participants on the transition of Lake Moawhitu from a mahinga kai site to that based on farming brought deep emotions tied to memories of their past and the stories of their whanaunga.

It is hoped that the Steering Committee's (Fig. 23) focus on plugging the drains and returning the farmland to a wetlands system will be instrumental to its functioning as well as restoring much needed habitat for tuna and other native fish.

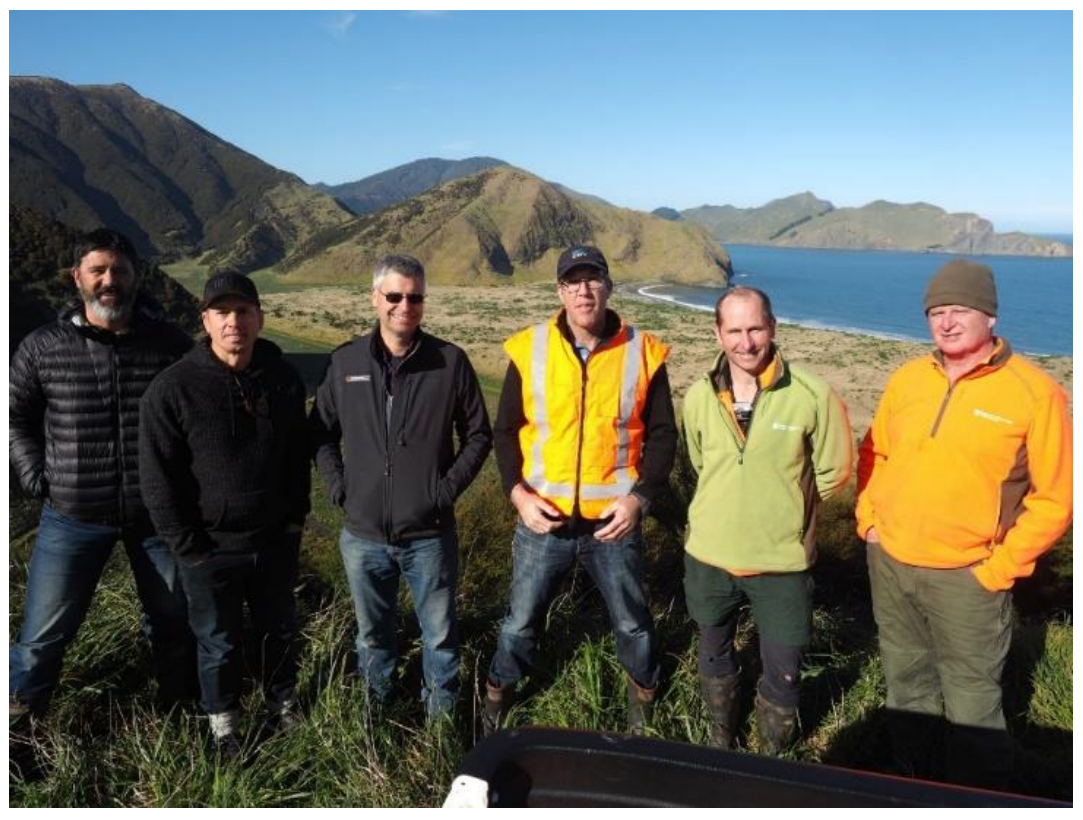

Figure 23: Kairangahau, along with Lake Moawhitu and Wetlands Restoration Steering Committee members.

Dan Moore, DoC Project Manager for Lake Moāwhitu Wetlands Restorative Programme has been driving the restorative project at Moāwhitu and provides useful insights into how distinct cultures with unique ways of being and knowing simply get on with the task and make it work within a kaupapa Māori framework (Appendix 3) which has been instrumental for 
kaitiaki to reconnect to whenua. Without the voice of manawhenua and tūpuna i.e. drawing from past experiences at Moāwhitu, significant historical gaps would likely remain in terms of tuna vegetation and water quality. Their voice and that of iwi cultural advisors ensured a kaupapa Māori approach was adopted, from karakia to waiata and simply acknowledging the history and spiritual connection, helped to steer this waka's restorative strategy and efforts. Participants were able to provide examples, locations, and chronological markers supporting either researched data or other accounts relating to water levels in the lake and wetlands, vegetation, pastoral land use impacts e.g water quality, as well as tuna population decline (from commercial take, reduced/poor habitat, etc).

It is these aspirations of kaitiakitanga that tūpuna would strongly encourage.

Wetekia Ruruku Elkington (Grandma/kuia to Puhanga), a mareikura (female of noble birth) and matakite (seer), 'was gifted with insight - her dreams prepared her right from the very young age of six' upon the passing of her mother in the late 1800s to be a leader amongst her people. She was entrusted with enormous responsibility and her 'brilliant memory stored tikanga, korero, waiata, tribal history, whakapapa, and an understanding and active knowiedge of the gospel (christianity). She was a very intelligent, beautiful woman, generous to a fault who shared her increase with others' and was that repository of knowledge for her Koata people through to the 1950s. Wetekia continues to be that repository of knowledge for her people to draw from.

It would be convenient to speak to the mauri mate of Lake Moawhitu owing to changes in land use over the past century. It would be of greater purpose to speak to its life potential given the sustenance it once gave to Koata. For this reason the need to engage Wetekia, our kaumātua and kuia at wananga and kanohi ki te kanohi was deliberate and aligns well to what Puhanga expresses:

The only reason why it won't work [i.e. to restore the mauri] is because there are no kaumātua, no tūpuna to continue that whakaaro, and that's a great pity. My great fortune was living with old people who had the wairua. [...] In those days your grandparents tell you where you can and can't go. Everything has a wairua. The sea's got a wairua. If you are attuned to that wairua, you will [be] having nothing but joy in the encounter, and you know how to behave (interview with Puhanga, May 2019). 
At wānanga, kaumātua and kuia alike expressed their intent and aspirations. This was encapsulated by Pirihira who explains:

All things being possible, l'd like see it [Lake Moāwhitu] totally restored to the way it used to be in every aspect, in health and size. He moemoeā tēnā [that is my dream] (Wananga, June 2019).

Rosemary Hippolite endorses Pirihira's moemoeā:

For me, it's a place where our young people can learn again the traditions (Wānanga, May2019).

Rawenata Gieger confirms their commitment to restoration:

We would like to see it restored back to its natural state, no brown mucky around the side of it...take it back to what it was (Wānanga, June 2019).

Rangatiratanga remains in their hands and those willing and able to support the kaupapa ensuring this wāhi tapu that is Moawhitu is respected and in time might be restored as a fully functioning mahinga kai site for our iwi.

\section{Findings}

The significance of heke Koata, the departure of their tūpuna from their ancestral homelands and the perilous heke endured to arrive and take hold of their new home, the tūrangawaewae for Koata, is expressed and felt through wairua. In this respect, Lake Moawhitu is wāhi tapu in the sense that it was a significant place to Koata kaitiaki for mahinga kai, where knowledge through interwoven experiences was generated based on whakapapa and whanaungatanga. Over the past several decades Moawhitu has become a place where wairua and mauri has diminished significantly. Until wairua and the mauri is restored, i.e. when the lake and wetlands returns to full health, only then does it become mahinga kai and the status as wāhi tapu can be removed. This understanding is brought about through aTe AoMāori lens, understanding that wāhi tapu will enable a healing process to take place until full restitution is complete. 
Observation and analysis through a Te Ao Māori lens has historically been problematic for non-Indigenous researchers. This is largely because degradation to water quality and resultant impact on fish populations from pollutants due to altered land use is scientifically researched as an independent study, often independent of its connection to people, purpose, and without understanding the fuller impacts on mauri and wairua. Traditionally, and over time, Māori were able to read the landscape, the environment in which they lived and what was happening within their takiwā and their ecosytem. This involved acknowledging atua and their influence on the elements, and relying on the senses to assess the measures of mauri i.e. well-being of their ecosystem

In 2018 a Cultural Health Index (CHI) assessment monitoring programme for Moawhitu that 'relied on the senses' was being developed by Ngāti Koata Environmental Manager Frank Jarom Hippolite (Appendix B). These senses include sight, smell, sound, touch and taste in assessing vegetation in lake versus catchment, bird variety and abundance, water colour and smell, tuna and native fish populations (e.g. catch volume during harvest season) to name a few. Such a monitoring tool enables manawhenua to apply traditional methods through active engagement within the Moāwhitu ecosystem. The $\mathrm{CHI}$ also provides resource agencies pathways to weave cultural perspectives and values into managerial decision making practices. Using these cultural health indicators moving forward, Koata kaitiaki will be able to conduct a total ecosystem assessment of the lake and adjacent wetlands. In partnership with the Department of Conservation, Lakes380, and kaitiaki, the aim is to bring back into balance the mauri and wairua of Lake Moawhitu and to restore this highly valued cultural and ecological site to mahinga kai status through the process of kaitiakitanga and rangatiratanga (i.e. the authority to act and make decisions concerning the resources within your tribal area, Tipa, 2009). This $\mathrm{CHI}$ assessment will potentially both inform and be informed from this thesis including the Moawhitu restorative work currently underway by Koata-DoC.

Drawing from tūpuna such as Wetekia and our modern day kaumātua/kuia provides a sense of connection that transcends the physical into the spiritual realm and demonstrates an awareness that underlies why Moāwhitu, why whanaungatanga, and indeed tuna is meaningful. Through this knowledge and realisation, kaitiaki, may also draw from, and for those afar, perhaps awaken to the significance of their own tūrangawaewae of Rangitoto ki te Tonga. 


\subsection{DISCUSSION}

Nāu te rourou, nāku te rourou, ka ora ai te iwi - (With your food basket and my food basket the tribe (all) will benefit).

This section discusses the main findings presented in the previous sections (5.1-5.5) in the context of key commentaries on mātauranga and its interfacing with western Science.

This case study demonstrates how mātauranga Māori embodies experiences built on relationships between people, place, and tuna. Further, this case study demonstrates the distinction between mātauranga Māori and mātauranga-a-iwi (Wilkinson et al., 2020), with the latter emphasising the importance and significance of a particular location (Moawhitu) or taonga species (tuna) to a particular iwi (Koata). In this thesis whakapapa is the backbone whereby cultural connection to place and resources i.e. mātauranga-a-iwi, is formed and recorded through several media including narratives and experiences which together validate connection to the resource, use of the resource (mahinga kai), and a 'sense' of "wellbeing" (Awatere et al, 2017).

It is whanaungatanga and whakapapa that explain these relationships (Carbough, 2007; cited by Tipa, 2009). These relationships and how they connect are viewed holistically through aTe AoMāori lens that traditionally differs to a western science objective approach which may study the tuna in isolation, disconnected from their relationship to Māori, whanaungatanga and whakapapa. What is now understood by whakapapa, the whole tuâkana-teina relationship and what this means to Ngāti Koata as explained by Taonui (2011, citing Mitira, 1972) provides western science a clearer point of engagement with mātauranga Māori. This is important in terms of how both parties are willing to engage more effectively knowing that all participants have a theoretical and/or practical grasp of what whakapapa means in the context of relationships to tuna, their health and regeneration.

With a better understanding of the tuākana-teina relationship and the experiential link to place and people, mahinga kai can be seen by western science participants through the perspective of manawhenua. Knowing that intimate knowledge on tuna varieties, hī-tuna, and tuna heke has been passed down by whakapapa through mediums of oral and visual methodologies may support more effective engagement at the interface (Te Tau Ihu Mahi 
Tuna, 1999). Tuna is more than a food source to Māori. Ngāti Koata understand that where permission is granted by Tuna to be used as a resource for teina (Māori, who are higher up on the food chain), an exchange occurs. Karakia is traditionally given before hi-tuna, before the hunting and gathering occurs signifying an exchange based on reciprocity and respect which in one way explains why wastage from mahinga kai goes against tikanga. The expanding body of knowledge that is mātauranga Māori is an iterative and dynamic process where knowledge is continuously accumulated and re-applied through the practice of mahinga kai and kaitiakitanga. This Indigenous knowledge was not fixed, static, or only 'traditional', but is adaptive, expanding and evolving whilst drawing on the past. The western science world view would reflect a similar approach although some proponents may dispute the tenets of Indigenous knowledge giving rise to a raft of tensions between the two knowledge streams (Medin and Bang, 2014, cited by Mercier, 2018). Puhanga succinctly put things into perspective by assessing the changing face of Aotearoa and that:

Emerging more into a Pākeha world', it was safer not to know and/or practice strict kawa (Interview with Puhanga Tupaea, May 2019).

In other words, Koata adapted and took on those strands of western knowledge that would work for them, and that would continue to enable them to have meaning in their lives without compromising traditional practices.

In light of these contrasting approaches to study, and in the face of simmering tensions, mātauranga Māori continues to rely on multi-sensory assessment of an ecosystem's health and well-being, explains Tipa (2009). This practice-based application of 'the senses' is evidenced in a traditional cultural health assessment model which is akin to a western science methodological approach reliant on observation and experimentation. Hikuroa (2016) describes this approach as being consistent with the scientific methodology based on evidence, incorporating culture and values, and explained according to a Māori world view. Yet a western science approach typically views things within an objective and independent context that studies individual parts of an ecosystem. Hikuroa (2018) asserts that "both knowledge streams are methodologically created within a world view", where a western science separation of 'fact from values' potentially creates disconnect between an ecosystem's component parts. The implications are that by being attuned to slight ecosystem 
variations through mahinga kai, Māori can readily identify the source, the cause, and actual or potential impacts to the ecosystem as a whole (Hikuroa, 2016) enabling, if required, the role of hunter-gatherer to shift to that of kaitiaki. The change in land use to farming included the draining of Moawhitu which created a significant shift in mahinga kai practice for manawhenua. Realising the human impacts to their significant sites struck a chord with participants at wananga, during interviews, and was heard through historical accounts.

By acknowledging that these tensions remain, we sometimes see how two different world views i.e. exponents of western science and matauranga are often guilty of talking past one another by using different language and terminology. An example in this thesis is Fig 8 (chapter 3, pg.33 - Latin pollen diagram), which has been instrumental in guiding the western science effort, however, is virtually meaningless to Koata. Why? Latin names, which are insulting to those who are unfamiliar with them. Further I consider this wasteful of western science to ignore the centuries of development of mātauranga embedded in 'Te Wao Nui a Taane'. And yet, the solution is obvious. By weaving a te reo Māori thread into the biophysical basket, reciprocity and respect is achieved through acknowledgment and inclusiveness. The Moāwhitu te reo pollen diagram (Fig. 4.6) developed in this thesis is one example of how this might occur.

More generally, this thesis is an example of how two knowledge streams can flow in the same direction and come together beneficially, but the process has to be ground-truthed, driven by manawhenua, supported by other relevant stakeholders such as DoC and Regional Councils. For example, from wānanga the local distinction between wharariki and the more common harakeke (Phormium tenax, which is more commonly known as flax). Koata kaumātua were able to speak of the local wharariki as a soft shorter flax that was used as a softer fabric by women e.g. for making piu piu. This contrasts with the traditional use of harakeke which is for for weaving baskets, mats, and other uses e.g. mahinga kai (interview with wānanga participants). In this way, wharariki is seen as a local taonga species linked to the mauri of the lake, highlighting the importance of matauranga-a-iwi in informing restorative efforts.

The importance of reciprocity and respect in maintaining ecological balance (Tipa, 2009) cannot be overstated. A duty of care over the natural world and in this case Lake Moawhitu is, according to Koata, an inherent responsibility shared by the iwi collectively. This perhaps 
differs from a western science approach which historically has tended to use knowledge for control rather than to provide a sense of belonging (Hikuroa, 2017). Despite "...the harms done to Indigenous knowledge and mātauranga Māori since colonialization", Tauwhare (2008) highlights the opportunities for Māori led initiatives in developing a new way of knowledge production. The key is interface collaboration that draws on the traditional richness of both knowledge baskets (Tauwhare, 2008). By encouraging an 'acceptance of the other', common ground is created to give scientists and mātauranga holders a more comfortable point of engagement (Mercier, 2018).

In the context of Kaitiakitanga, perhaps rather than comparing the differences, Cheung contends the challenge is "holding both world views side by side." Cheung (2008) asserts herein lies the "potential for Māori to make unique contributions to science" which in this case may reveal specific findings by tying people to tuna through place and potentially contributing to the Koata-DoC restoration programme.

To go beyond the 'how this collaboration will work' is to delve further into more practical ways of engagement enabling alignment and synergy. This is where a case can be made for western science to adopt these principles (values) of reciprocity and respect as a holistic way to restore tuna health and populations through manawhenua, and for mātauranga to have space to breath and find its own voice and its own ways of doing that has meaning for Mãori, for kairangahau, and Māori stakeholders in this contemporary space (Smith et al 2016).

The Lakes380 national study of freshwater lakes has taken such an approach by collaborating with iwi, hapū, and whānau in respect to their whenua, their roto, before engaging their methodologies within the takiwā (Ellison, Martin, Smith; Lakes380 Māori engagement consultants). Such findings are then shared with manawhenua kaitiaki either for iwi, hapū, whānau purposes, or as a collaborative exchange of knowledge towards ecological remediation. Tipa (2009) suggests that a long term partnership with non-Indigenous groups based on trust and respect towards freshwater sustainability is the way forward. The political and practical possibilities of holding both world views side by side as described by Cheung (2008) can work when acknowledging the respective methodologies employed and findings obtained that contribute to a collective repository of new and/or relevant knowledge. 


\section{CHAPTER 5 - SyNTHESIS AND CONCLUSION:}

Mā pango, mā whero ka oti te mahi refers to how different peoples or cultures collaborate through combined efforts based on a mutual purpose to achieve their goals.

This thesis demonstrates the synergistic benefits of working with these two rich knowledge baskets. From western science a picture emerges of long-term environmental changes in respect to vegetation, habitat and water quality and aligned to historical reference states. In particular, the western science stream has been able to put the recent observations of water quality into a longer-term context in relationship to land use changes in the past few centuries. What the Western Science knowledge stream has not yet been able to show, however, is a clear history of tuna at Lake Moawhitu. The mātauranga-a- iwi stream on the other hand provides historical knowledge on tuna population, health, size, type, traditions, whakapapa, and connection to people and place. From this knowledge stream, the picture emerges of a thriving sustainable relationship between tuna and people at Moawhitu that persisted across several generations at least; and that this relationship has broken down in recent decades. By putting these knowledge baskets together, this thesis shows that the decline of tuna - and Koata at Moawhitu - can be understood in the context of the declining lake ecosystem (mate mauri) of recent decades in tandem with the alienation of Ngati Koata and the breakdown of their tuākana-teina relationship.

Me hoki whakamuri kia haere whakamua. With the knowledge drawn from these two baskets we can have more confidence in the current effort to restore the mauri of the lake to mahinga kai status. However, as Puhanga points out, this restoration will not be complete without the return of kaumātua and tūpuna to continue that whakaaro. In other words, the restoration needs to enhance tuna habitat, health, and populations by planting littoral species and restoring lake water levels and quality, but it needs to do more. Only once restoration is genuinely guided through kaitiakitanga, informed by tikanga-a-tūpuna and kaumatua, vested in kairangahau, can we be truly confident of a return to sustainable harvesting practices. This critical observation could not be reached through western science alone. Through a Te Ao Māori lens, a full and complete restoration of place connects to its people, Koata. It is Koata that is key to resuming mahinga kai at Moawhitu through a return to a traditional customary 
harvest practice of tuna. When that happens, mate mauri, even wāhi tapu will be lifted so that Moāwhitu can once again sustain an abundance of life and be more than just an idyllic place to look at. Rather, it will once again be a place where tuākana and teina connect.

But a problem remains. The two knowledge streams can explain what has happened and why and what needs to be done, but they cannot tell us how....?

It is fitting therefore that the final word comes from tūpuna through the voice of Wetekia.

\section{A VOICE FROM THE DUST}

Wetekia, who was at the forefront of many of those changes spanning the late 1800 s to mid 1900s, a phase of intense colonialisation, was the power and heart of Koata and remains the voice for her people today. She is also a voice for guiding how the two knowledge baskets can work together: how do these two distinct knowledge streams converge, mix, and flow in one direction?

The title of my thesis one could argue is a whakataukī, from tūpuna constantly reminding and exhorting the current generation of their role and duty as kaitiaki. Tuna also have a literal and figurative voice calling from the sediment beneath Lake Moawhitu to teina (their younger sibling,) to sustain their posterity, as they had once sustained human life.

For Ngāti Koata, the same title could also represent the words of ancient peoples that are inscribed and recorded on plates of precious metal buried for many generations until discovered in the $19^{\text {th }}$ century (e.g., Hamblin, 2007). These plates speak of whanaungatanga, kaitiakitanga, whakapapa, and wairua providing constant reminders of our humanity, kindness, and indeed respect for all things. It is these values espoused by Koata mareikura Wetekia that are embedded deep in her whakaaro, her wairua. This ancient record also speaks of wars, conflict, death and grief, and the many tensions that have emerged through history reflecting inequalities, injustices, and intolerance. Fiction or not, perhaps this ancient message was written for future generations to take heed and remember the lessons of the past, to heed the voice from the dust.

It was certainly an unwavering guide for Wetekia who exemplified and epitomised the best of humanity. The how is not 'rocket science'. It is an ability to put ego, pride, and other 
human frailties to one side in an effort to heed the call of Papatūānuku. In this case it is to restore ecosystem balance, to restore the life of Moāwhitu; its mauri. It is the voice of Wetekia, who could see beyond her years to present day and, as a voice from the dust, calls to her people as a reminder of what is important in this world. How working together, sharing knowledge, informing, including, and acknowledging each other can only enhance and accelerate restorative efforts. A master of the seas, Wetekia could navigate extreme weather conditions, fish, hunt, and provide for her iwi but she did so in a sustainable manner, with respect for the resource.

Manaaki tangata is a Te Ao Māori perspective on respect and reciprocity which goes deeper and speaks to the depth and conviction of a person to offer manaaki to 'he tangata' (a person/s). It speaks of a person's essence (kiko) which puts indifference and inhibitions aside in order to make others feel welcome, comfortable, and fed whilst in each other's presence. With Covid-19 ever present our global family is forced to find new ways of 'doing' by interweaving multiple knowledge strands in a collective struggle to stabilise a world health crisis. We have seen to good effect how many Nations have protected and sustained their people and how compassion and kindness have been integral to these efforts. Extreme times require creative collaboration based on enduring principles. Wetekia was the epitome of human kindness, of manaaki tangata, this is the essence of how the two knowledge baskets work together.

He aha te mea nui o te ao. He tāngata, he tāngata, he tangata.

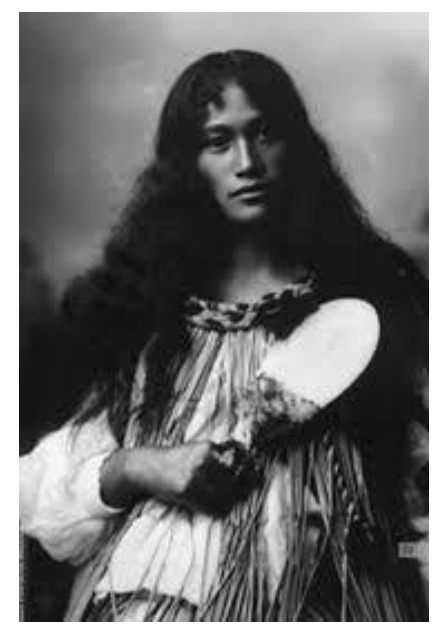

Figure 23. Wetekia Ruruka Elkington - Māreikura, Ngāti Koata 


\section{REFERENCES}

Acou, A., Robinet, T., Lance, E., Gerard, C., Mounaix, B., Brient, L., Le Rouzic, B. and Feunteun, E. (2008), Evidence of silver eels contamination by microcystin LR at the onset of their seaward migration: what consequences for breeding potential? Journal of Fish Biology, 72: 753-762. doi:10.1111/j.1095-8649.2007.01726.x

Allison SD, Martiny JBH . (2008). Resistance, resilience, and redundancy in microbial communities. PNAS 105: 11512-11519.

Anderson AJ (1991) The chronology of colonization in New Zealand. Antiquity 65:767-795.

McWethy DB, Whitlock C, Wilmshurst JM, McGlone MS, Li X (2009) Rapid deforestation of South Island, New Zealand by early Polynesian fires. The Holocene 19: 883-897.

Arai, T., Kotake, A., Lokman, M., Miller, M., and Tsukamoto, K. (2004) 'Evidence of different habitat use by New Zealand freshwater eels Anguilla australis and A. dieffenbachii, as revealed by otolith microchemistry', Marine Ecology Progress Series, 266, pp. 213-225. ; http://www.doc.govt.nz/nature/native-animals/freshwater-fish/eels/.

August, S. M., \& Hicks, B. J. (2008). Water temperature and upstream migration of glass eels in New Zealand: implications of climate change. Environmental Biology of Fishes, 81(2), 195205. doi:10.1007/s10641-007-9191-z

Awatere, S., Harmsworth, G., \& Robb, M. (2017). Mātauranga Māori: Māori knowledge. Te reo o te repo-The Voice of the Wetland: Connections, Understandings and Learnings for the Restoration of Our Wetlands. Lincoln, NZ: Manaaki Whenua-Landcare Research, 151-155.

Bassett, Heather, and Richard Kay. (2000) 'Nga Ture Kaupapa o Ngati Koata ki te Tonga, c 1820-1950'. Report commissioned by the Crown Forestry Rental Trust (Excerpts of Oral Interviews conducted by Iwi historian, Josephine Paul), (doc A76). 
Beentjes, M. P., Jellyman, D. J., \& Kim, S. W. (2006). Changing population structure of eels (Anguilla dieffenbachii and A. australis) from southern New Zealand. Ecology of Freshwater Fish, 15(4), 428-440. doi:10.1111/j.1600-0633.2006.00165.x

Bergin, D. O., FitzSimons, P., Freeman, C., Herbert, J. W. and Kesby, N. A. (1997). Managment of Marram Grass in the Resoration of Indigenous Coastal Dune Vegetation in Australia and New Zealand. Paper accepted for The Pacific Coasts and Parks Conference, 711 Sept. Christchurch, New Zealand.

Bowman, J. S., \& Ducklow, H. W. (2015). Microbial Communities Can Be Described by Metabolic Structure: A General Framework and Application to a Seasonally Variable, DepthStratified Microbial Community from the Coastal West Antarctic Peninsula. PLoS ONE, 10(8), e0135868. https://doi.org/10.1371/journal.pone.0135868.

British Science Council. (2009). Our definition of Science. Retrieved from: http://sciencecouncil.org/about-us/our-definition-of-science/.

Broad, T.L., Townsend, C.R., Closs, G.P. and Jellyman, D.J. (2002), Riparian land use and accessibility to fishers influence size class composition and habitat use by longfin eels in a New Zealand river. Journal of Fish Biology, 61: 1489-1503. https://doi.org/10.1111/i.10958649.2002.tb02492.x.

Burnet, Alfred Maxwell Ralph. (1952), "Studies on the ecology of the New Zealand longfinned eel, Anguilla dieffenbachii Gray." Marine and Freshwater Research 3.1: 32-63.

Butz, C. Grosjean, M. Goslar,T. Tylmann, W. (2017), Hyperspectral imaging of sedimentary bacterial pigments: a 1700-year history of meromixis from varved Lake Jaczno, northeast Poland J. Paleolimnol. pp. 1-16.

Callahan, B. J., McMurdie, P. J., Rosen, M. J., Han, A. W., Johnson, A. J. A., \& Holmes, S. P. (2016). DADA2: high-resolution sample inference from Illumina amplicon data. Nature Methods, 13(7), 581. 
Carbaugh, D. (2007). Cultural discourse analysis: Communication practices and intercultural encounters. Journal of International Communication Research, 36(3): 167-182.

Chariton, A. a, Court, L. N., Hartley, D. M., Colloff, M. J., \& Hardy, C. M. (2010). Ecological assessment of estuarine sediments by pyrosequencing eukaryotic ribosomal DNA. Frontiers in Ecology and the Environment, 8(5), 233-238. https://doi.org/10.1890/090115.

Chen, H., Li, A., Cui, D., Cui, C., \& Ma, F. (2019). Evolution of microbial community and key genera in the formation and stability of aerobic granular sludge under a high organic loading rate. Bioresource Technology Reports, 7, 100280.

Cheung, M. (2008). The reductionist-holistic worldview dilemma. MAl review, 3(5), 1-7.

Chisnall, B.L., \& Kalish, J.M., (1993) Age validation and movement of freshwater eels (Anguilla dieffenbachii and $A$. australis) in a New Zealand pastoral stream, New Zealand Journal of Marine and Freshwater Research, 27:3, 333-338, DOI: 10.1080/00288330.1993.9516573.

Craig L. Stevens, Kura Paul-Burke (Ngāti Awa Ngāti Whakahemo) \& Peter Russell (Ngāpuhi) (2020). Pūtahitanga: the intersection of western science and mātauranga Māori in the context of Aotearoa New Zealand's physical oceanography. New Zealand Journal of Marine and Freshwater Research. DOI: 10.1080/00288330.2019.1698621.

Crawford, S. (2009). Mātauranga Māori and western science: The importance of hypotheses, predictions and protocols. Journal of the Royal Society of New Zealand 39(4).

Crengle, H. (2002). "The legal basis for a consideration of the cultural values of the Ngai Tahu". In Cultural impact assessment - Project Aqua, Edited by: Tipa, G., Crengle, H., Davis, K., Allingham, B. and Symon, A. Christchurch, New Zealand: Meridian Energy. 
Cristescu, M. E., \& Hebert, P. D. N. (2018). Uses and misuses of environmental DNA in biodiversity science and conservation. Annual Review of Ecology, Evolution, and Systematics, 49(1), 209-230. https://doi.org/10.1146/annurev-ecolsys-110617-062306.

Darling JA, Pochon X, Abbott CL, Inglis GJ, Zaiko A. The risks of using molecular biodiversity data for incidental detection of species of concern. Diversity and Distributions. 2020 Sep;26(9):1116-21.

Davey, Andrew \& Jellyman, D. (2005). Sex Determination in Freshwater Eels and Management Options for Manipulation of Sex. Reviews in Fish Biology and Fisheries. 15. 3752. 10.1007/s11160-005-7431-x.

Department of Conservation DoC and National Office Caleb Royal and Pātaka Moore Te Wānanga o Raukawa (2014). Tuna ā tātou taonga Whakatauākī.

Department of Conservation DOC (1992). Pingao Recovery Plan Otago Conservancy 19931998. Department of Conservation, Dunedin.

Domaizon I, Winegardner A, Capo E, Gauthier J, Gregory-Eaves I. DNA-based methods in paleolimnology: new opportunities for investigating long-term dynamics of lacustrine biodiversity. Journal of Paleolimnology. 2017 Jun 1;58(1):1-21.

Drinan (2018). Freshwater ecological surveys at Moāwhitu Lake outlet and Wetland, (NovDec), Department of Conservation (DoC).

Durie, M. (2004) Understanding health and illness: research at the interface between science and Indigenous knowledge, International Journal of Epidemiology, Volume 33, Issue 5, October 2004, Pages 1138-1143, https://doi.org/10.1093/ije/dyh250.

Ellison R, Martin R, Smith R. Lakes380 Māori Engagement Consultants (2018 - current). Faegri K, Kaland PE and Krzywinski K (1989) Textbook of Pollen Analysis. 4th edn. Chichester: Wiley. 
Fonseca, V. G., Carvalho, G. R., Sung, W., Johnson, H. F., Power, D. M., Neill, S. P., Packer, M., Blaxter, M. L., Lambshead, P. J. D., Thomas, W. K., \& Creer, S. (2010). Second-generation environmental sequencing unmasks marine metazoan biodiversity. Nature Communications, 1. https://doi.org/10.1038/ncomms1095.

Glova, G., Jellyman, D., and Bonnett, M. (1998) 'Factors associated with the distribution and habitat of eels (Anguilla spp.) in three New Zealand lowland streams', New Zealand Journal of Marine and Freshwater Research, 32(2), pp. 255-269.

Graynoth, E., Jellyman, D.J. and Bonnett, M.L. (2008). Spawning escapement of female longfin eels. New Zealand fisheries assessment report 2008/7. Wellington: Ministry of Fisheries.

Graynoth, E.; Taylor, M.J. (2000). Influence of different rations and water temperatures on the growth rates of shortfinned and longfinned eels. Journal of Fish Biology 57: 681-699.

Hajibabaei M, Shokralla S, Zhou X, Singer GA, Baird DJ. (2011). Environmental barcoding: a next-generation sequencing approach for biomonitoring applications using river benthos. PLoS one. Apr 13;6(4):e17497.

Hamblin, William J. (2007) "Sacred Writing on Metal Plates in the Ancient Mediterranean," Review of Books on the Book of Mormon 1989-2011: Vol. 19 : No. 1 , Article 8. Available at: https://scholarsarchive.byu.edu/msr/vol19/iss1/8.

Harke, M. J., Steffen, M. M., Gobler, C. J., Otten, T. G., Wilhelm, S. W., Wood, S. A., \& Paerl, H. W. (2016). A review of the global ecology, genomics, and biogeography of the toxic cyanobacterium, Microcystis spp. Harmful Algae, 54, 4-20.

Harmsworth, Garth R., and Shaun Awatere. (2013). "Indigenous Māori knowledge and perspectives of ecosystems." Ecosystem services in New Zealand-conditions and trends. Manaaki Whenua Press, Lincoln, New Zealand: 274-286. 
Henao, E., Rzymski, P., \& Waters, M. N. (2020). A review on the study of cyanotoxins in paleolimnological research: current knowledge and future needs. Toxins, 12(1), 6.

Hicks, B.J., McCaughan, H.M.C. (1997). Distribution of fish and crayfish, and eel production, in streams in forest and pasture in the Waikato Region, New Zealand. New Zealand Journal of $\begin{array}{llll}\text { Marine } & \text { and } & \text { Freshwater } & \text { 31(5): 635- }\end{array}$ 650. http://www.tandfonline.com/doi/abs/10.1080/00288330.1997.9516795 .

Hikuroa, D. (2017). Mātauranga Māori - the ūkaipō of knowledge in New Zealand. Journal of the Royal Society of New Zealand 47(1): 5-10. doi:10.1080/03036758.2016.1252407.

Ho Susie S., Bond Nick R., Lake P. Sam (2011) Comparing food-web impacts of a native invertebrate and an invasive fish as predators in small floodplain wetlands. Marine and Freshwater Research 62, 372-382. doi.org/10.1071/MF10222

Jacoby, D. et al (2015) 'Synergistic patterns of threat and the challenges facing global anguillid eel conservation', Global Ecology and Conservation, 4, pp. 321-333. https://www.niwa.co.nz/te-kūwaha/tuna-information-resource/biology-andecology/spawning-grounds.

Jansen, H., Winter, H., Bruijs, M., and Polman, H. (2007) 'Just go with the flow? Route selection and mortality during downstream migration of silver eels in relation to river discharge', ICES Fournal of Marine Science, 64(7), pp. 1437-1443.

Jara, I.A.; Newnham, R. M. et al. (2015). Pollen-climate reconstruction from northern South Island, New Zealand's $\left(41^{\circ} \mathrm{S}\right)$ reveals varying tropical and extra-tropical influences over the last 16,000 years. Journal of Quaternary Science 30, 817-829.

Jellyman, D.J. (2012). The status of longfin eels in New Zealand - An overview of stocks and harvest. Report prepared for Parliamentary Commissioner for the Environment. NIWA. 
Jellyman D,J. (2007). Status of New Zealand fresh-water eel stocks and management initiatives. Ices Journal of Marine Science 64.

Jellyman, D. J., Graynoth, E., Francis, R. I. C. C., Chisnall, B. L., \& Beentjes, M. P. (2000). A review of evidence for a decline in the abundance of longfinned eels (Anguilla dieffenbachii) in New Zealand. NIWA Report for Ministry of Fisheries Research Project EEL9802.

Jellyman, D.J. (1989). Diet of two species of freshwater eel (Anguilla spp.) in Lake Pounui, New Zealand. New Zealand Journal of Marine and Freshwater Research 23: 1-10.

Karetu, T. (1975).Language and Protocol of the Marae [meeting place], in Te Ao Hurihuri, ed Michael King, Longman Paul, Auckland.

Keck F, Millet L, Debroas D, Etienne D, Galop D, Rius D, Domaizon I. (2020). Assessing the response of micro-eukaryotic diversity to the Great Acceleration using lake sedimentary DNA. Nature Communications. 11(1):1-8.

Kelly DJ, Moore D, Stewart S, Waters S, Roberson H. (2019). Approaches for the restoration of water quality and aquatic health in Lake Moāwhitu. Prepared for Department of Conservation. Cawthron Report No. 3329. 57p. plus appendices.

King, Darren \& Shaw, Wendy \& Meihana, Peter \& Goff, J. (2018). Māori oral histories and the impact of tsunamis in Aotearoa-New Zealand. Natural Hazards and Earth System Sciences. 18. 10.5194/nhess-18-907-2018.

Klindworth A., Pruesse E., Schweer T., Peplies J., Quast C., Horn M., Glöckner FO. (2013). Evaluation of general $16 \mathrm{~S}$ ribosomal RNA gene PCR primers for classical and next-generation sequencing-based diversity studies. Nucleic Acids Research 41:1-11. DOI: 10.1093/nar/gks808. 
Kozich JJ, Westcott SL, Baxter NT, Highlander SK, Schloss PD. (2013). Development of a dualindex sequencing strategy and curation pipeline for analyzing amplicon sequence data on the MiSeq Illumina sequencing platform. Applied and environmental microbiology. 79(17):5112-20.

Lam, P., \& Kuypers, M. M. (2011). Microbial nitrogen cycling processes in oxygen minimum zones. Annual review of marine science, 3, 317-345.

Lee, J. (2009). Decolonising Māori narratives: Pūrākau as method. MAI Review 2(3):1-12.

Lee, J. (2008). Ako: Pūrākau of Māori teachers' work in secondary schools. [Unpublished PhD thesis]. Auckland, New Zealand: University of Auckland.

Māori Dictionary. (2003). Definition of mātauranga Māori. Retrieved 2016 Jul 29.

McCaughan (2015). Moāwhitu, d'Urville: Glass eel and whitebait recruitment. Department of Conservation (DoC), October 2015.

McCaughan (2015). Moāwhitu, d'Urville: Tuna heke and system health. Department of Conservation (DoC), April 2015.

McCaughan (2014). D'Urville Island, Greville Harbour: Fish survey - Department of Conservation (DoC), 1 to 4 December 2014.

McGlone, M., \& Wilmshurst, J. (1999). A Holocene record of climate, vegetation change and peat bog development, east Otago, South Island, New Zealand. Journal of Quaternary Science: Published for the Quaternary Research Association, 14(3), 239-254.

McGlone MS, Wilmshurst JM. (1999). Dating initial Maori environmental impact in New Zealand. Quaternary International 59: 5-16. 
McGlone, M. (1989). The Polynesian settlement of New Zealand in relation to environmental and biotic changes. New Zealand journal of ecology, 12(Supplement), 115-129.

McGlone MS. (1983) Polynesian deforestation of New Zealand: a preliminary synthesis. Archaeology in Oceania 18: 11-25.

McMurdie PJ, Holmes S. (2013). Phyloseq: an R package for reproducible interactive analysis and graphics of microbiome census data. PloS one. Apr 22;8(4):e61217.

McSaveney, E. (2006) 'Tsunamis - New Zealand's tsunami history', Te Ara - the Encyclopaedia of New Zealand, http://www.TeAra.govt.nz/en/tsunamis/page-2 [accessed 7 May 2018].

McWethy, David \& Whitlock, Cathy \& Wilmshurst, Janet \& McGlone, Matt \& Li, Xun. (2009). Rapid deforestation of South Island, New Zealand, by early Polynesian fires. Holocene. 19. 883-897. 10.1177/0959683609336563.

Medin, D., Bang, M. (2014). Who's Asking? Native Science, Western Science and Science Education. Cambridge, MA: MIT Press.

Mercier, O. R. (2018). Mātauranga and science. New Zealand science review, 74(4), 83-90.

Moore, Pataka. (2013). Statement on behalf of Ngāti Pareraukawa - Submission to Primary Production Select Committee.

Morgan, K., Manuel, R. (2020). Western science and Indigenous wisdom: is integration possible, practical, plausible?. New Zealand Science Reviews 76, 6-12.

Newnham RM et al (2018). Two-step human-environmental impact history for northern New Zealand linked to late Holocene climate change. The Holocene 28, 1093-1106.

Nozhevnikova, A. N., Holliger, C., Ammann, A., \& Zehnder, A. J. B. (1997). Methanogenesis in sediments from deep lakes at different temperatures $\left(\begin{array}{lll}2-70 & \mathrm{C}\end{array}\right)$. Water Science and Technology, 36(6-7), 57-64. 
Ogden, John \& Deng, ym \& Horrocks, M. \& Nichol, Scott \& Anderson, Sandra. (2006). Sequential impacts of Polynesian and European settlement on vegetation and environmental processes recorded in sediments at Whangapoua Estuary, Great Barrier Island, New Zealand. Regional Environmental Change. 6. 25-40. 10.1007/s10113-005-0006-5.

Parai, R.I (2018). Development of a quantitative PCR assay for the detection of New Zealand freshwater eels (tuna) in environmental samples. Science 301 Victoria University of Wellington.

Parai, R.I. (2019-a). Research Proposal - Tuna health in Lake Moāwhitu: using environmental DNA and mātauranga Māori to learn from the past and guide future aspirations, Science 301 Victoria University of Wellington.

Parai, R.I. (2019-b). Moāwhitu Lake and Wetland Complex: Tuna population status, customary fishery objectives, and an implementation pathway for a cultural harvest model at Lake Moāwhitu on d'Urville Island. Prepared for Department of Conservation.

Pätete, A., (1997). 'D'Urville Island (Rangitoto ki te Tonga) in the Northern South Island', report commissioned by the Waitangi Tribunal, (doc A32).

Pätete, A. (2008) Te Tau Ihu o te Waka a Māui: report on Northern South Island claims. (Waitangi Tribunal report). ISBN 978-1-86956-294-6.

Pruesse E, Quast C, Knittel K, Fuchs BM, Ludwig W, Peplies J, Glöckner FO. (2007). SILVA: a comprehensive online resource for quality checked and aligned ribosomal RNA sequence data compatible with ARB. Nucleic acids research. Dec 1;35(21):7188-96.

Rutledge (2013). Tuna and native fish populations of Lake Moāwhitu and wetland drains, Greville Harbour. Department of Conservation.

Rutledge (2007). Native fish communities of Moāwhitu Lake and Wetland, Greville Harbour, D’Urville Island: May 2007 Survey. Department of Conservation.

Rutledge (2005). Greville Harbour Property - fisheries and aquatic habitat values including Management recommendations. Department of Conservation. 
Sassoubre LM, Yamahara KM, Gardner LD, Block BA, Boehm AB. (2016). Quantification of environmental DNA (eDNA) shedding and decay rates for three marine fish. Environmental science \& technology. Oct 4;50(19):10456-64.

Smith, L., Maxwell, T., Puke, H., Temara, P. (2016). Indigenous knowledge, methodology and mayhem: What is the role of methodology in producing Indigenous insights? A discussion from mātauranga Māori. Knowledge Cultures. (3): 131-156.

Smith, L.T. (1996). Kaupapa Māori research: Some Kaupapa Māori principles, adapted from a paper presented at Massey University.

Smol, J. P. (2017). Conservation biology and environmental change: a paleolimnological perspective. In Conservation Paleobiology: Science and Practice (pp. 31-43). University of Chicago Press.

Taberlet, P., Bonin, A., Zinger, L., \& Coissac, E. (2018). Environmental DNA: For Biodiversity Research and Monitoring. Oxford University Press.

Taberlet P, Coissac E, Hajibabaei M, Rieseberg LH. (2012). Environmental DNA. Molecular ecology. (Apr);21(8):1789-93.

Taonui, Rāwiri. (2020). 'Whakapapa - genealogy', Te Ara - the Encyclopedia of New Zealand, http://www.TeAra.govt.nz/en/whakapapa-genealogy/print (accessed 4 July).

Tauwhare, S.E.K. (2008). Dancing at the Interfaces: Ways of Doing. The Interfaces between Indigenous Knowledge's and Western Science. [MPhil Thesis], Massey University, Palmerston North.

Te Tau Ihu Eel Management Committee (1999). Te Tau Ihu Mahi Tuna-Eel Management Plan. 
Team, R. C. (2014). A language and environment for statistical computing. $R$ Foundation for Statistical Computing, 73, 3-36. Vienna, Austria.

Thomson-Laing G, Parai R, Kelly LT, Pochon X, Newnham R, Vandergoes MJ, Howarth J, Wood SA (in review, 2020). Development of droplet digital Polymerase Chain Reaction assays for the detection of long-finned (Anguilla dieffenbachii) and short-finned (Anguilla australis) eels in environmental samples. Environmental DNA.

Tipa, G. (2009) Exploring Indigenous Understandings of River Dynamics and River Flows: A Case from New Zealand, Environmental Communication, 3:1, 95120, DOI: $\underline{10.1080 / 17524030802707818 .}$

Walker, R. (1994). Te Karanga: Suppressed Knowledge. Metro 157: 129-130.

Wang, Q., Garrity, G. M., Tiedje, J. M., \& Cole, J. R. (2007). Naive Bayesian classifier for rapid assignment of rRNA sequences into the new bacterial taxonomy. Applied and Environmental Microbiology, 73(16), 5261-5267.

Wardle, P. (1991). Vegetation of New Zealand. Cambridge University Press-Cambridge, New York, ISBN 0-521-25873-1.

Whitton, B. A., \& Potts, M. (Eds.). (2007). The ecology of cyanobacteria: their diversity in time and space. Springer Science \& Business Media.

Wilmshurst JM, Anderson AJ, Higham TFG, Worthy TH (2008) Dating the late prehistoric dispersal of Polynesians to New Zealand using the commensal Pacific rat. Proceedings of the National Academy of Sciences of the United States 105: 7676-7680.

Zaiko A, Wood S, Pochon X, Biessy L, Laroche O, Croot PL, Garcia-Vazquez E. (2020 in press) Elucidating biodiversity shifts in ballast water tanks during a cross-latitudinal transfer: complementary insights from molecular analyses. Environmental Science \& Technology. 
KUPU MĀORI - GLOSSARY

Mōteatea

Nā wai ka hoki ki tō mātou tūpuna a Tangaroa, ki a Papatūānuku, ki te one ō raro, ki te puehu.

E kore rawa e rangona anōtia ō mātou reo, haere rā...

\begin{tabular}{|c|c|}
\hline A & \\
\hline Aotearoa & New Zealand \\
\hline awa & River \\
\hline H & \\
\hline Haerenga & Journey \\
\hline hapū & $\begin{array}{l}\text { kinship group, the primary politial unit in traditional Māori } \\
\text { society }\end{array}$ \\
\hline heke & to walk, to migrate \\
\hline hiahia & Aspiration, hope, desire, \\
\hline hui & gathering, assembly, meeting, conference \\
\hline I & \\
\hline iwi & $\begin{array}{l}\text { large group of people descended from a common ancestor and } \\
\text { associated with a distinct territory }\end{array}$ \\
\hline K & \\
\hline kai & Food \\
\hline kaiapotanga & All consuming greed \\
\hline kaiponutanga & Mindless actions \\
\hline kairangahau & Researcher \\
\hline
\end{tabular}




\begin{tabular}{|c|c|}
\hline kaitiaki & a giver of protection, guardian, carer \\
\hline kaitiakitanga & $\begin{array}{l}\text { What does kaitiakitanga mean to whānau who contributed to } \\
\text { this project? }\end{array}$ \\
\hline kānohi ki te kānohi & face to face interaction, in-person \\
\hline kānohi kitea & To have a physical presence, seen face in person \\
\hline karakia & prayer, incantation \\
\hline karangatia & To cry out \\
\hline kaumātua & elders, grandparents \\
\hline kaupapa Māori & $\begin{array}{l}\text { Māori ideology, Māori pespective, approach derived from } \\
\text { mātauranga Māori }\end{array}$ \\
\hline Kawea atu & To depart \\
\hline koha & donation, gift with thought, contribution \\
\hline koiwi & Māori/Human skeletal remains \\
\hline kōrero & to speak, conversation \\
\hline kotahitanga & unity, as one, solidarity, collective \\
\hline kupu & Word \\
\hline Kūwharuwharu & Taonga species, the long fin tuna (native New Zealand eel) \\
\hline \multicolumn{2}{|l|}{ M } \\
\hline mahinga kai & garden, cultivation, food gathering place \\
\hline mana & $\begin{array}{l}\text { respect, prestige; note that authority that can only be } \\
\text { bestowed upon someone or something and cannot be given to } \\
\text { oneself }\end{array}$ \\
\hline
\end{tabular}




\begin{tabular}{|c|c|}
\hline manaakitanga & $\begin{array}{l}\text { The capacity to care, the flowing of hospitality, the generosity } \\
\text { of spirit which lifts us up and binds us together, to act in a } \\
\text { mana-enhancing manner }\end{array}$ \\
\hline Manaaki tangata & $\begin{array}{l}\text { The act and art of giving sustenance and making others feel } \\
\text { comfortable in each others presence }\end{array}$ \\
\hline mana whenua & $\begin{array}{l}\text { kinship grouping with territorial authority over an area; } \\
\text { territorial rights }\end{array}$ \\
\hline marae & $\begin{array}{l}\text { complex of buildings or structures including wharenui } \\
\text { (ancestral meeting house), wharekai (place for eating) and } \\
\text { wharepaku (place for bathing and toilets) }\end{array}$ \\
\hline maramataka & $\begin{array}{l}\text { The turning of the moon, a guide when to fish, garden and } \\
\text { conduct other activities in the natural world }\end{array}$ \\
\hline mātauranga Māori & $\begin{array}{l}\text { Māori knowledge - the body of knowledge originating from } \\
\text { Māori ancestors, including the Māori world view and } \\
\text { perspectives, Māori creativity and cultural practices }\end{array}$ \\
\hline manuhiri & visitor, guest \\
\hline mareikura & Supreme Goddess and nobly born female \\
\hline mātua & parents \\
\hline maunga & Mountain \\
\hline mauri & $\begin{array}{l}\text { life force - the essential quality and vitality of a being or entity. } \\
\text { Also used for a physical object, individual, ecosystem or social } \\
\text { group in which this essence is located. }\end{array}$ \\
\hline mihimihi & formal greeting, introduction \\
\hline moana & ocean, sea \\
\hline moko / mokopuna & grandchild / grandchildren \\
\hline
\end{tabular}




\begin{tabular}{|c|c|}
\hline mōteatea & Trational chant, to lament, to be apprehensive \\
\hline \multicolumn{2}{|l|}{$\mathbf{N}$} \\
\hline $\begin{array}{l}\text { ngā moemoea a kui mā a } \\
\text { koro mā }\end{array}$ & aspirations of the older generation \\
\hline \multicolumn{2}{|l|}{0} \\
\hline Oranga & Living, life, survivor \\
\hline \multicolumn{2}{|l|}{$\mathbf{P}$} \\
\hline Pākehā & non-Māori \\
\hline Papatūānuku & $\begin{array}{l}\text { Earth Mother, earth diety, wife of Ranginui from which all } \\
\text { living things originate from them }\end{array}$ \\
\hline pataka & food storage structure \\
\hline pātata & Close or near \\
\hline pepeha & $\begin{array}{l}\text { Identifies a person by linking them to place and people } \\
\text { through whakapapa and time }\end{array}$ \\
\hline pōtae & literally, a hat; figuratively, a role or position one holds \\
\hline Puehu & dust \\
\hline Puna wai & Spring water, water source, water ways \\
\hline \multicolumn{2}{|l|}{ pūrākau } \\
\hline \multicolumn{2}{|l|}{$\mathbf{R}$} \\
\hline rangatahi & Youth \\
\hline rangātira & leader, chief, weaving together of people \\
\hline
\end{tabular}




\begin{tabular}{|c|c|}
\hline Ranginui & $\begin{array}{l}\text { Sky Father, sky diety, husband of Papatūānuku from which all } \\
\text { living things originate from them }\end{array}$ \\
\hline Reo & Voice, language \\
\hline rohe & region, territory, area of land \\
\hline rongona & To hear \\
\hline rōpū & Group of people \\
\hline Roto & Lake \\
\hline \multicolumn{2}{|l|}{$\mathbf{T}$} \\
\hline tangata whenua & people of the land, local people \\
\hline tangi / tangihanga & to cry and weep, funeral \\
\hline taonga & object of social and cultural value, treasured possession \\
\hline tapu & $\begin{array}{l}\text { sacred - a person, place or thing is dedicated to an atua and is } \\
\text { thus removed from the sphere of the profane and put into the } \\
\text { sphere of the sacred. It is untouchable, no longer to be put to } \\
\text { common use. }\end{array}$ \\
\hline tauā & war party \\
\hline tautoko & to support \\
\hline Teina & Younger sibling \\
\hline te ao Māori & Māori worldview and perspective \\
\hline te ao hurihuri & the ever-changing and evolving world \\
\hline te moemoeā & dreams, visions, aspirations \\
\hline Te Tiriti o Waitangi & $\begin{array}{l}\text { The Treaty of Waitangi was signed in } 1840 \text { between the Crown } \\
\text { and Māori chiefs. There are two versions - one in English (the }\end{array}$ \\
\hline
\end{tabular}




\begin{tabular}{|c|c|}
\hline & $\begin{array}{l}\text { Treaty) and the other in Māori (te Tiriti). Essential differences } \\
\text { between the two texts have given rise to different } \\
\text { interpretations that are still being worked through today }\end{array}$ \\
\hline Te Tau Ihu & region at the top of the South Island \\
\hline Te Wai Pounamu & South Island of New Zealand \\
\hline tikanga & $\begin{array}{l}\text { Māori cultural protocol, the customary system of values and } \\
\text { practices that have developed over time and are deeply } \\
\text { embedded in the social context }\end{array}$ \\
\hline tohunga & an expert in their field or a spiritual guider \\
\hline toitū & To be sustainable \\
\hline tokoiti & A few or small number of people \\
\hline Tuakana & Elder sibling \\
\hline tūpuna/tīpuna & ancestors, grandparents \\
\hline turangawaewae & A place to stand, the whenua that connects your identity \\
\hline \multicolumn{2}{|l|}{$\mathbf{U}$} \\
\hline Uri & Descendants, offspring \\
\hline urupā & burial ground \\
\hline \multicolumn{2}{|l|}{$\mathbf{W}$} \\
\hline wāhi tapu & sacred place or sacred space \\
\hline waiata & Song \\
\hline Whakataukī & A Māori proverb, a significant saying \\
\hline waka & $\begin{array}{l}\text { a vessel (typically a canoe) that carries and transports people } \\
\text { or objects }\end{array}$ \\
\hline
\end{tabular}




\begin{tabular}{|c|c|}
\hline wānanga & to meet and discuss, deliberate, consider \\
\hline wairua & spiritual element, spiritual energy, soul \\
\hline whakairo & To carve, ornament with a pattern \\
\hline whakamana & empower, authorise, validate \\
\hline whakapapa & geneology, lineage, kinship \\
\hline Whakarongo & listen \\
\hline whakataukī & To utter a proverbs \\
\hline whānau & $\begin{array}{l}\text { immediate and extended family group, family group, kinship } \\
\text { group }\end{array}$ \\
\hline whānaunatanga & $\begin{array}{l}\text { Strengthening of relationships and kinship between } \\
\text { people/whanau, embedded in whakapapa }\end{array}$ \\
\hline whenua & Land \\
\hline
\end{tabular}


Clusters of question types aligned to key themes/cultural values:

Cluster 1: Whakapapa of interviewee; where they grew up and/or their earliest association with Rangitoto ki te Tonga/d'Urville; their work/family role (the pōtae they wear)

What is your name and how do you whakapapa to Ngati Koata?

Describe the Island and its significance to you and your whanau?

Cluster 2: Place-centred connections to Rangitoto ki te Tonga and Lake Moawhitu; significance of place names and their meanings; wāhi tapu; childhood memories; Koata memories of events such as the tsunami.

What was the significance of this lake to you, whanau and iwi growing up?

What do you remember about the lake's historical significance i.e. place names and meanings, wāhi tapu, childhood memories, events?

Cluster 3: Mātauranga Māori of tuna: tikanga and mātauranga with respect to tuna (generic to Māori); tikanga and protocols/practices specific to Ngāti Koata that have been handed down from their tūpuna; what is still practised today?

What tikanga handed down by your tūpuna are still known or practised today in respect to tuna?

Is there any significance/connection in detecting tuna's historical presence in the lake and its whakapapa?

In respect to whakapapa and our tūpuna, what is your understanding of a 'voice from the dust'? 
Cluster 4: Te Ao Hurihuri: observations of environmental, social and cultural changes to Lake Moāwhitu and to tuna populations; kaitiaki issues and concerns

Describe the condition or state of Lake Moawhitu when you were growing up there/visiting there (i.e. water quality, vegetation)?

Describe the tuna population, health, size, colour, life cycle, varieties/names in Lake Moāwhitu

What stories do you recollect from your parents, grandparents, tūpuna about tuna harvesting in Lake Moāwhitu?

Cluster 5: Te Moemoeā: aspirations, hopes/dreams and priorities for the health, wellbeing, mauri and sustainability of tuna for the future; what we need to do today to ensure that...

What does the mauri of the lake mean to you? (life-force, quality and vitality of the lake, its spirit) and is it a priority to restore the mauri of Lake Moāwhitu?

Show photos of how it looks today. How do these photos compare with your recollection of Lake Moāwhitu and how it used to look?

If cultural harvest were to occur in the future, what needs to happen? 
APPENDIX B - A GUIDE FOR WHAT A CULTURAL HEALTH INDICATOR (CHI) FORM COULD LOOK LIKE FOR MOAWHITU

The $\mathrm{CHI}$ is a tool that Ngāti Koata will use to assess and manage the cultural and biological health within the Lake Moāwhitu catchment. These ratings provide baseline data for ongoing monitoring, detection and evaluation of adverse changes within the catchment.

Each section is categorized under specific atua (e.g. Tangaroa) and assessed under specific criteria before an overall assessment of wairua and mauri is applied to the results.

Ultimately this tool provides recommended pathways towards site restoration i.e from mauri mate (a diminished or 'sick' life force) to mauri ora (restoring the mauri).

\begin{tabular}{|c|c|c|c|c|}
\hline Date: & \multicolumn{4}{|c|}{$\begin{array}{l}\text { Return Status: } 1=\text { Return for harvest or management, } \\
0=\text { Will not return for harvest or management }\end{array}$} \\
\hline & \multicolumn{4}{|c|}{$\begin{array}{l}\text { Rating }=\text { Ratings will vary between the different } \\
\text { domains of the Atua. As an Example: Tangaroa Rating } \\
\text { can mean } 1=\text { Area disturbed by human/animals, } 5= \\
\text { Area undisturbed and is pristine. }\end{array}$} \\
\hline Time: $\quad$ Low or High Tide: & & & & \\
\hline \multicolumn{5}{|l|}{ Weather: } \\
\hline \multicolumn{5}{|l|}{ Name of iwi monitor: } \\
\hline Tangaroa & Rating 1-5 & Rating 1-5 & Rating 1-5 & Comments \\
\hline \multicolumn{5}{|l|}{ 1. Estuary edge } \\
\hline \multicolumn{5}{|l|}{ 2. Channel condition } \\
\hline \multicolumn{5}{|l|}{ 3. Lake Water Clarity/Quality } \\
\hline \multicolumn{5}{|l|}{ 4. Seawater/Freshwater interface } \\
\hline 5. Estuarine habitats (wet part) & & & & \\
\hline
\end{tabular}




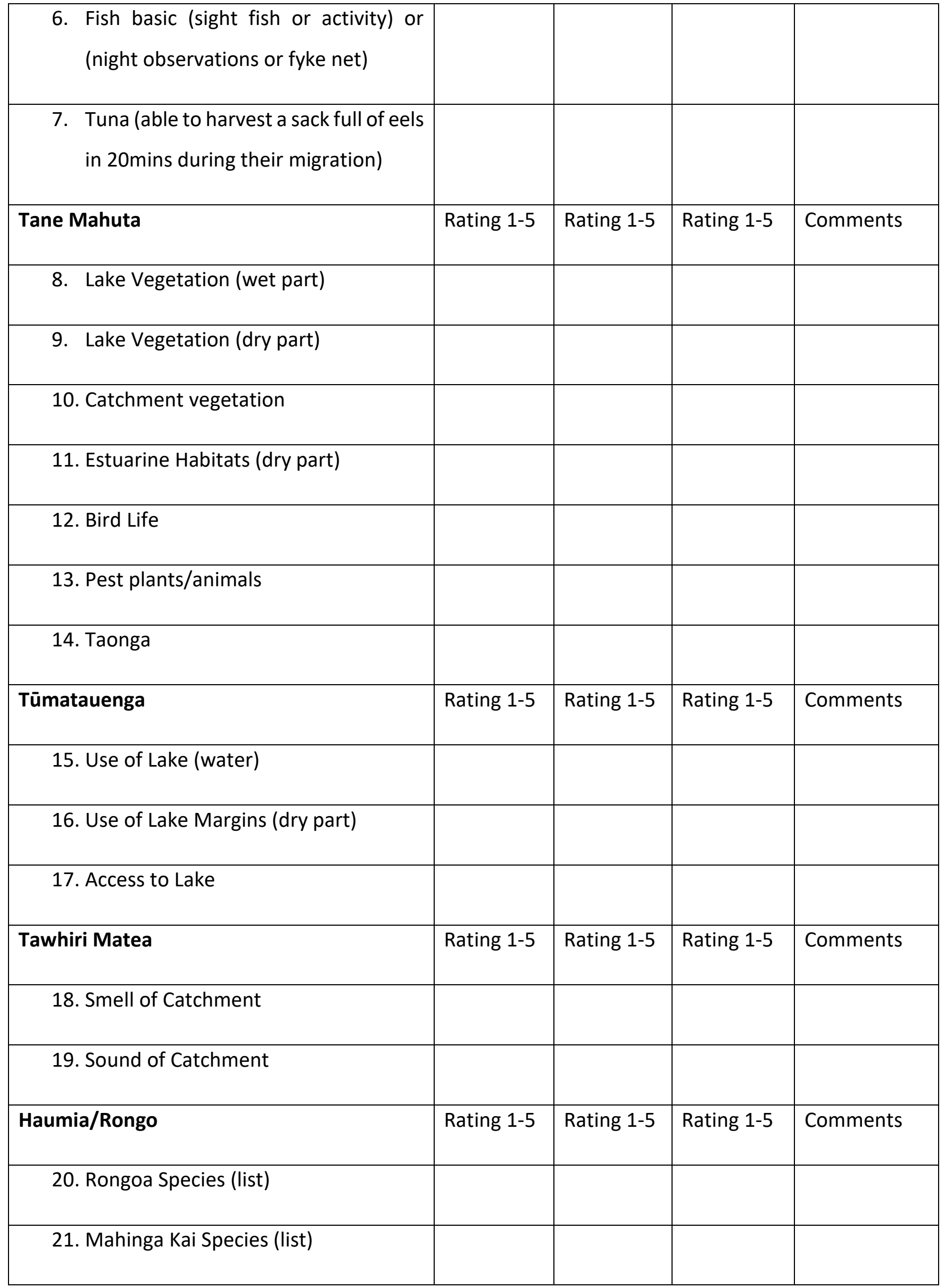




\begin{tabular}{|c|l|l|l|l|}
\hline 22. Mahinga Kai today & & & & \\
\hline 23. Mahinga Kai traditional & & & & \\
\hline Overall Wairua/Mauri & Rating 1-5 & Rating 1-5 & Rating 1-5 & Comments \\
\hline 24. Feeling in puku & & & & \\
\hline 25. CHI Score (office) & & & & \\
\hline 26. Comments & & & & \\
Action Points & & & & \\
Recommendations & & & \\
\hline
\end{tabular}


Dan Moore - DoC Project Manager for Lake Moāwhitu Wetlands Restorative Programme highlights the importance of a voice from the iwi, kaumātua and kuia alike, including tūpuna. Without their voice drawing from past experiences at Moāwhitu, significant historical gaps would likely remain i.e. tuna presence, abundance, and health; vegetation types and uses; and water quality. Their voice and that of iwi cultural advisors ensured a kaupapa Māori approach was adopted, from karakia to waiata and simply acknowledging the history and spiritual connection, helped to steer this waka's restorative strategy and efforts.

Dan Moore shares the following:

Te Ao Māori provides past knowledge that science alone cannot reveal or find.

Your investigations into kaumatua korero has revealed important knowledge that may not have been found out through science alone.

Examples include: korero on 'small trout in tank'-helped us understand about probable populations of banded or giant kokopu at Moāwhitu.

Kaumātua korero on harvesting tuna when 'spring high tide breached the lake' - alongside historical diagrams etc help us focus research on certain areas and understand past hydrological regimes.

Koiwi and other archaeological sites (e.g. middens, pakohe etc) help to identify that the area was a large food basket with a significant population of kai for te tau ihu iwi.

\section{Cultural safety within ecological restoration}

Cultural understanding of landscapes especially at Moāwhitu have helped to keep the efforts of staff and volunteers to keep culturally safe during the time we have spent at the site. Examples include:

\section{$\underline{\text { Karakia before mahi }}$}

Identifying sensitive areas e.g. koiwi and other archaeological sites. Identifying processes around accidental discoveries to keep people safe.

Cultural monitors on hand to help with operations e.g. during earthworks to install drainplugs. Provide context to operators of the kaupapa of the project.

Helping to interpret mauri and wairua as separate and different to basic interpretations of ecosystems and ecology

Kaupapa 
Koata's approach of identifying key kaupapa for the project (tuna populations, mauri and wairua) has been key in defining what outcomes will make the project a success. For example when iwi can once again harvest tuna from Moawhitu it will be a measure of ecological, mauri, wairua restoration. This is a crucial measure that science alone cannot define but can sit alongside e.g. fish surveys/monitoring, plants surveys, habitat enhancement to achieve tuna harvests.

\section{$\underline{\text { Korero }}$}

As different to just straight 'exchanges of conversation', its felt like 'korero' between DOC and Ngāti Koata has other factors - mutual respect, understanding, willingness to learn from the past. This has felt important over the past two years and I think has been crucial to the successes we have had and failures we have learnt from.

Ngā mihi nui

Dan Moore 